FINAL TECHNICAL REPOR'T

FOR GRANT DE-FGO2-90ER60943

submitted to

CARBON DIOXIDE RESEARCH PROGRAM

OFFICE OF HEALTH AND ENVIRONMENTAL RESEARCH

U. S. DEPARTMENT OF ENERGY

WASHINGTON, D. C. 20545

\title{
INVESTIGATION OF CARBON DIOXIDE IN THE SOUTH ATLANTIC AND NORTHERN WEDDELL SEA AREAS \\ (WOCE SECTIONS A-12 AND A-21) DURING THE METEOR EXPEDITION 11/5, JANUARY-MARCH, 1990
}

\author{
by \\ David W. Chipman, Taro Takahashi, Dee Breger \\ and Stewart C. Sutherland \\ Lamont-Doherty Geological Observatory of Columbia University, \\ Palisades, N. Y. 10964
}

December, 1991 


\section{TABLE OF CONTENTS}

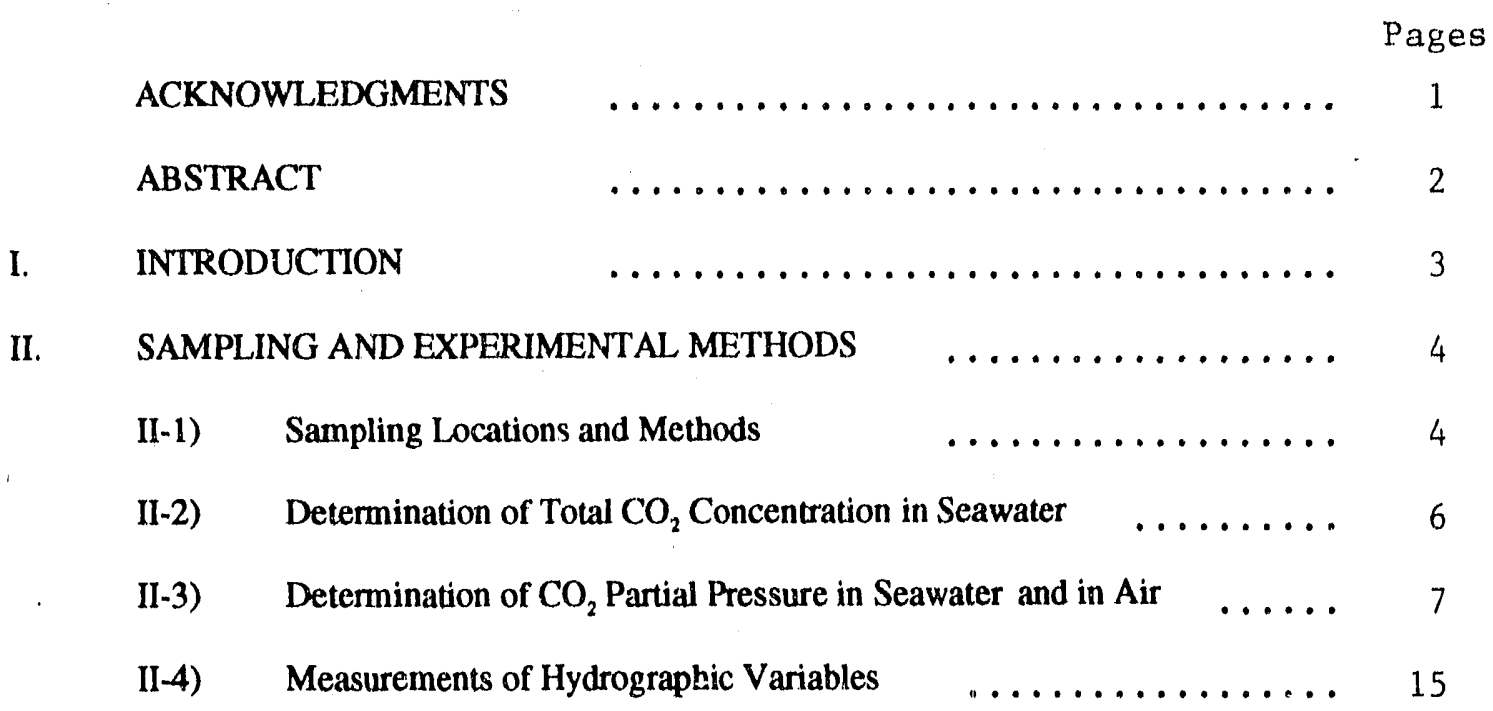

III. DISTRIBUTION OF OCEANOGRAPHIC PROPERTIES $\ldots \ldots \ldots \ldots \ldots \ldots$

III-1) Distribution of Properties in Surface Waters $\quad \ldots \ldots \ldots \ldots \ldots \ldots$

III-2) The Drake Passage (N-S) Section (Stations 102-121) $\ldots \ldots \ldots \ldots 22$

III-3) The Northern Weddell Sea Section (Stations 122-131) $\ldots \ldots \ldots$. . . . 35

III-4) The $58^{\circ} \mathrm{S}$ Section (Stations 132-149) $\ldots \ldots \ldots \ldots \ldots \ldots$

III-5) The Captetown-Weddell Section (Stations 149-179) $\ldots \ldots \ldots \ldots \ldots$

III-5-a) Southern Capetown-Weddell Section (Stations 149-164) $\ldots \ldots \ldots$. . 62

III-5-b) Northern Capetown-Weddell Section (Stations 164-179) $\ldots \ldots \ldots$

VI. PROPERTY-PROPERTY RELATIONSHIPS $\ldots \ldots \ldots \ldots \ldots \ldots$

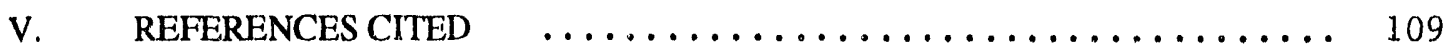

IV. DATA TABLES $\ldots \ldots \ldots \ldots \ldots \ldots \ldots \ldots \ldots \ldots \ldots \ldots \ldots \ldots \ldots \ldots$ 


\section{ACKNOWLEDGMENTS}

This investigation has been supported by a grant from the U. S. Department of Energy (No. DE-FGO2-90ER60943). We thank Drs. Michael Riches and John Downing (on leave from the Battelle Northwest Laboratories) of the Department of Energy for support and encouragement. The field work was conducted aboard the F/S METEOR of the Federal Republic of Germany. The concentrations of dissolved oxygen and nutrient salts were determined by Jim Costello and David Boss of the Oceanographic Data Facility, Scripps Institution of Oceanography; the salinity was determined mainly by Jose Arango of the Argentine Hydrographic Office; and the CTD was operated jointly by the Scripps' ODF staff and German scientists and technicians. We thank Dr. Wolfgang Roether of the University of Bremen, for scientific collaboration, and the captain and crew members of the METEOR for their effective assistance provided to us during the expedition. 


\section{ABSTRACT}

This report summarizes the results of investigation the oceanographic expedition aboard the F/S METEOR in the South Atlantic Ocean including the Drake Passage (WOCE Section A-21), the northern Weddell Sea and the eastern South Atlantic (WOCE Section A-12) during the austral summer of January through March, 1990. The total $\mathrm{CO}_{2}$ concen- tration in about 1300 seawater samples and $\mathrm{CO}_{2}$ partial pressure $\left(\mathrm{pCO}_{2}\right)$ in about 870 seawater samples collected at 77 stations were determined aboard the ship using a coulorneter and equilibrator/gas chromatograph system. The temperature, salinity, dissolved oxygen and nutrient salt data presented in this report were deiermined by other participants of the expedition including the members of the Oceanographic Data Facility of the Scripps Institution of Oceanography, Argentine Hydrographic Office and German institutions.

For each of the properties including temperature, salinity, potential density at $2000 \mathrm{db}$, total $\mathrm{CO}_{2}$, $\mathrm{pCO}_{2}$, oxygen and nutrient salts, the data are presented in five sets of contoured sections; a N-S section across the Drake Passage ( $\left(56^{\circ} \mathrm{S}-63^{\circ} \mathrm{S}\right)$, a NW-SE section in the northern Weddell Sea $\left(45^{\circ} \mathrm{W}-35^{\circ} \mathrm{W}\right)$, a E-W section along the $58^{\circ} \mathrm{W}$ parallel $\left(25^{\circ} \mathrm{W}\right.$ - prime meridian), and two segmented S-N sections between the northern Weddell Sea and Capetown. The atmospheric and surface water $\mathrm{pCO}_{2}$ data show that the ocean was a weak to strong sink for atmospheric $\mathrm{CO}_{2}$ virtually over the entire tracks of the expedition. Across the Drake Passage (WOCE Section A-21), the following water masses have been identified; the Circumpolar Deep Water (CPDW), Southeast Pacific Low Oxygen Water (SPLOW), Southeast Pacific Deep Water (SPDW) and Southeast Pacific Bottom Water (SPBW). In the northern Weddell Sea section, the Weddell Sea Deep Water (WSDW), Weddell Sea Bottom Water (WSBW) and Antarctic Bottom Water (AABW) have been identified. In the Capetown- Weduell section, the following four water masses have been observed; the Antarctic Intermediate Water (AAIW), Upper and Lower Circumpolar Deep Waters (UCPDW and LCPDW), North Atlantic Deep Water (NADW) and Cape Basin Bottom Water (CBBW). The chemical properties for these water masses are summarized and the total $\mathrm{CO}_{2}, \mathrm{pCO}_{2}$ and alkalinity data have been found to he helpful in identifying and assessing the extent of some of these water masses. On the basis of property-property relationships between various properties, some regulatory processes and their relationships with oceanographic environments have been identified. In the surface water of the Atlantic Southern Ocean including the northem Weddell Sea, the total $\mathrm{CO}_{2}$ concentration normalized to $35 \mathrm{o} / 00$ salinity has been found to be linearly related to water temperature. Assuming that the air-sea $\mathrm{CO}_{2}$ flux is small, it has been estimated that about $80 \%$ of $\mathrm{CO}_{2}$ removed from surface water is by organic carbon production by photosynthesis and $20 \%$ by biogenic $\mathrm{CaCO}_{3}$ production. The surface water data show that the $\mathrm{CaCO}_{3}$ production occurs mainly in the subantarctic and subtropical regions where water temperatures are above $3^{\circ} \mathrm{C}$, whereas the production of siliceous organisms dominates in the Antarctic and Weddell Sea areas, where temperatures are less than $3^{\circ} \mathrm{C}$. 


\section{INTRODUCTION}

The deep interior of the oceans exchanges dissolved gases directly with the atmosphere when the deep water outcrops and becomes exposed to the atmosphere during winter in high latitude oceans. Thus, for our understanding of the $\mathrm{CO}_{2}$ cycle in the global ocean-atmosphere system, it is important to know various physical, chemical and biological processes controlling such exchange as well as the resulting distribution of $\mathrm{CO}_{2}$ in the high latitude oceans.

The high latitude South Atlantic Ocean occupies a unique place among the global oceans because of a number of major oceanographic features. Both the surface and deep waters enter into the Atlantic from the west through a topographically well defined channel, the Drake Passage located between the southern tip of the South America and the northern tip of the Palmer Peninsula of the Antarctic continent. The eastward flow in the sub-antarctic and antarctic areas constitutes the Atlantic sector of the Circumpolar Current. While these waters are in the Atlantic sector, they are modified via mixing with the more saline North Atlantic Deep Water, the outflow of the Weddell Sea and inflow (e.g. Agulhas Current) from the Indian Ocean. Furthermore, the deep waters outcrop during the winter and exchange gases and energy with the atmosphere in the sub-polar and polar regions. While some portion of these waters thus modified is transported to the north in the form of the Falkland (or Malvinas) Current in the sea surface regime, the Antarctic Intermediate Water in the mid-depth $(\sim 1000$ meters) regime and the Antarctic Deep Water (below about 3000 meters deep), the remainder flows out of the Atlantic to the Indian Ocean through the broad area between the southern Africa and Antarctic continents. The major objective of the present investigation is to determine the depth and geographic distribution of the total $\mathrm{CO}_{2}$ concen- tration and $\mathrm{pCO}_{2}$ in seawater over high latitude areas of the South Atlantic Ocean including the Drake Passage (WOCE Section A-2.1), the northern Weddell Sea and the eastern South Atlantic (WOCE Section A-12) areas. In addition, the distribution of temperature, salinity and the concentrations of dissolved oxygen and three nutrient salts and their relationships with $\mathrm{CO}_{2}$ are presented. 


\section{SAMPLING AND EXPERIMENTAL ME'THODS}

II-1) Sampling Locations and Methods:

The Cruise No. 11/5 of the F/S METEOR of the Federal Republic of Germany started at Ushuaia, Argentina, on January 21, 1990, and ended at Capetown, South Africa, on March 7, 1990. During the 45-day expedition in the South Atlantic and the Atlantic sector of the Southern Ocean, 177 stations were occupied along the WOCE sections A-21 and A-12. The station locations are shown in Fig. 1.

The water samples were collecteci by means of a 24-bottle rosette unit equipped with CTD. Ten-liter capacity "Niskin" samplers made of PVC were used for water sampling. Four to six pairs of protected and unprotected reversing thermometers were used for each cast for the purpose of calibrating the temperature and pressure sensors of the CTD. Water samples for the determination of total $\mathrm{CO}_{2}$ concentration and $\mathrm{pCO}_{2}$ were drawn directly from the Niskin samplers to respective sampling bottles after the water samples for the determinations of CFC's, Helium-3, and dissolved oxygen were drawn from each sampler. A 500-ml Pyrex reagent bottle equipped with a standard-tapered ground glass stopper (vacuum silicone grease as sealant) was used for the total $\mathrm{CO}_{2}$ samples and a 500 -ml long-neck Pyrex bottle equipped with a plastic screw top with a plastic sealing cone was used for the samples for $\mathrm{pCO}_{2}$ measurements. The sample bottles were rinsed three times with sample waters before the filling. About $5 \mathrm{ml}$ of head space was left in each bottle to prevent damages of bottles by thermal expansion of water during the storage. About 200 microliters of $50 \%$-saturated mercuric chloride solutions were added to each of these samples immediately after sample collection in order to prevent biological alteration of the samples during temporary storage. Most of the samples were analyzed within 24 hours, and all were done within 72 hours of collection, with the exception of surface water $\mathrm{pCO}_{2}$ samples in the Drake Passage section. The determination of $\mathrm{pCO}_{2}$ in the water samples collected in the Drake Passage were delayed several days after collection because of temporary malfunction of the gas chromatographic system. 
0

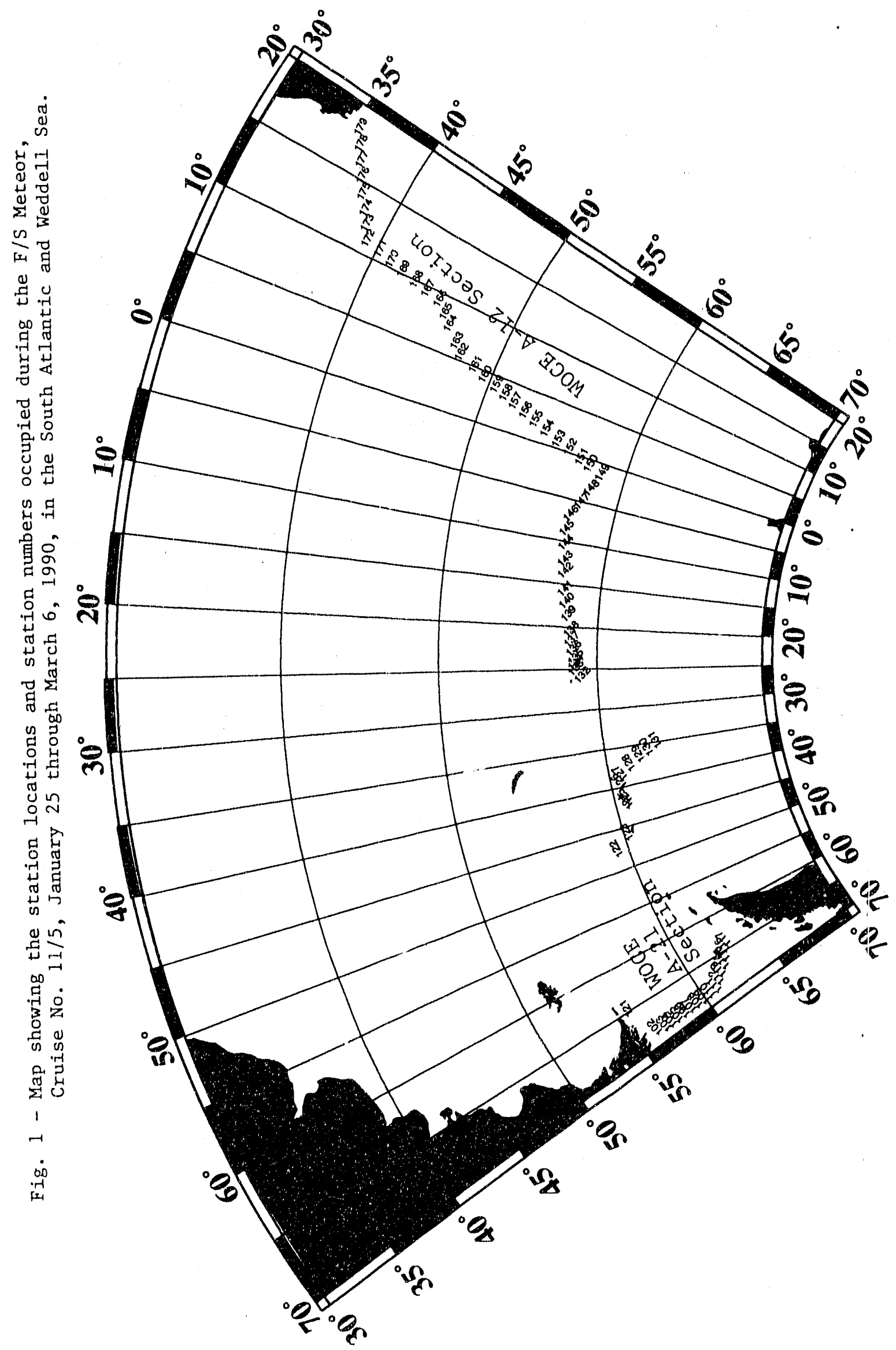


II-2) The Total $\mathrm{CO}_{2}$ Concentration in Seawater:

The total $\mathrm{CO}_{2}$ concentration $\left(\mathrm{TCO}_{2}\right.$ ) in seawater samples was determined using a coulometric system, which has been modified from the one described by Johnson et al. (1985).

For analysis, the seawater was introduced into the stripping chamber using fixed-volume syringes. The sample was acidified with $1 \mathrm{ml}$ of $8.5 \%$ phosphoric acid while in the stripping chamber, where the evolved $\mathrm{CO}_{2}$ gas was swept from the sample and transferred with a stream of $\mathrm{CO}_{2}$-free air into the electrochemical cell of the $\mathrm{CO}_{2}$ coulometer (UTC-Coulometrics Model-5011). In the coulometer cell, the $\mathrm{CO}_{2}$ is quantitatively absorbed by a solution of ethanolamine in dimethylsulfoxide (DMSO). Reaction between the $\mathrm{CO}_{2}$ and the ethanolamine forms the weak hydroxyethylcarbamic acid. The $\mathrm{pH}$ change of the solution associated with the formation of this acid results in a color change of thymophthalein $\mathrm{pH}$ indicator in the solution. The color change, from deep blue to colorless, is detected by a photodiode, which continually monitors the transmissivity of the solution. The electronic circuitry of the coulometer, on detecting the change in the color of the $\mathrm{pH}$ indicator, causes a current to be passed through the cell generating hydroxyl $\left(\mathrm{OH}^{-}\right)$ions from a small amount of water in the solution. The $\mathrm{OH}^{\cdot}$ generated titrates the acid, returning the solution to its original pH (and hence color), at which point the circuitry interrupts the current flow. The product of current passed through the cell and time is related by the Faraday constant to the number of moles of $\mathrm{OH}^{-}$generated to titrate the acid and hence to the number of moles of $\mathrm{CO}_{2}$ absorbed to form the acid.

The volumes delivered by the constant-volume syringes have been determined by repeatedly weighing distilled water dispensed in the same manner as a sample, and the volume calculated from the weight delivered, using the density of pure water at the temperature of the measurement and a buoyancy correction for the air displaced by the water (which amounts to about $0.1 \%$ of the weight of the water). The density of the seawater in the pipet was obtained at the temperature of injection using the International Equation of State (Millero et al., 1980).

The coulometer was calibrated using research grade $\mathrm{CO}_{2}$ gas $(99.998 \%)$ introduced into the carrier gas line upstream of the extraction tube, using a pair of fixed-volume sample loops on a gas sampling valve and measuring the pressure of the gas in the loops by venting it to the ambient atmosphere and determining the barometric pressure using the same elictronic barometer used with the $\mathrm{pCO}_{2}$ system; the loop temperature was measured to $\pm 0.05^{\circ} \mathrm{C}$ with a thermometer calibrated against one traceable to the NBS, and the non-ideality of $\mathrm{CO}_{2}$ was incorporated in the computation of the loop contents. The volume of the calibration loop had previously been determined by weighing empty and filled with mercury. The volumes of these loops have additionally been checked by comparing the amount of $\mathrm{CO}_{2}$ introduced by them with the amount derived from gravimetric samples of calcium car- 
bonate and sodium carbonate, and found to be accurate to within $0.1 \%$. During the expedition, the coulometer was calibrated several times daily using the calibrated loop and pure $\mathrm{CO}_{2}$ gas.

In order to evaluate the long term reproducibility and precision of the coulometric determination of $\mathrm{CO}_{2}$ in seawater, a number of sample bottles were filled with a homogeneous sample of surface water and deep water. Both Pyrex glass and PET plastic bottles (500 ml and $1000 \mathrm{ml}$ respectively) were used. These bottled samples were poisoned with mercuric chloride solutions $(200$ microliters fior each $500 \mathrm{ml}$ water sample) and analyzed for total $\mathrm{CO}_{2}$ during the expedition. The results are summarized in Fig. 2. Forty four determinations of the surface water samples conducted over 39 days at sea indicate a mean of $1965.2 \mathrm{uM} / \mathrm{kg}$ with a root mean square deviation of $\pm 1.0 \mathrm{uM} / \mathrm{kg}$ (see Fig. 2-A). Sixteen determinations of the deep water samples conducted over 13 days show a mean of 2262.2 $\mathrm{uM} / \mathrm{kg}$ with a root mean square deviation of $\pm 1.0 \mathrm{uM} / \mathrm{kg}$. Therefore, the precision for the total $\mathrm{CO}_{2}$ concentration values reported in this report have been estimated to be $\pm 1.0 \mathrm{uM} / \mathrm{kg}$. However, as mentioned earlier, the water samples for total $\mathrm{CO}_{2}$ analyses were collected from Niskin samplers after 1 to 2 liters of headspace was formed by the withdrawal of other water samples. Since marine air introduced into the headspace had lower $\mathrm{pCO}_{2}$ values than those for the seawater in samplers, especially after several degrees of warming occurred during hoisting, it is likely that $\mathrm{CO}_{2}$ was lost from the sample waters to the headspace. During the South Atlantic Ventilation Experiment (SAVE) program, the loss has been estimated by comparing the total $\mathrm{CO}_{2}$ concentrations determined for those from the 10-liter Niskin samples with those from the 280-liter Gerard samplers. Because of its large mass, the water temperature in a Gerard sampler changed little during hoisting from the sampling depth. In addition, hecause of the height (about 1.5 meters), an water sample drav/n from the base of the sampler was thought to be unaffected by the air introduced into the headspace. For these reasons, it was considered that little or no $\mathrm{CO}_{2}$ had been lost from the water samples withdrawn from Gerard samples. The results of nearly 40 pairs of comparison indicate that the deep water samples collected from the Niskin samplers appear to have lost no more than $2 \mathrm{uM} / \mathrm{kg}$ of $\mathrm{CO}_{2}$ before the seawater samples were transferred into the sample bottles.

II-3) Determination of $\mathrm{pCO}_{2}$ in Seawater:

A fully automated equilibrator-gas chromatograph system was used during the expedition $i \ldots$, the determination of partial pressure of $\mathrm{CO}_{2}$ exerted by the seawater samples. Its design and operation will be outlined below. Figure 3 gives a schematic diagram of this system.

The system consists of a pair of air circulation pumps (Spectrex Model AS-300-SS) plumbed to recirculate air through porous plastic gas dispersers which are immersed in two separate seawater sam- 
F1g. 2 - The results of repeated measurements at sea of the total $\mathrm{CO}_{2}$ concentration in surface (A) and deep (B) water samples. About 50 sample bottles were filled with a homogenized surface water sample and were analyzed over a 50-day pertod during the expedition. Only 20 bottles were filled with a homogenized deep water sample and analyzed subsequently over a period of 13 days. The analyses of these samples yield a mean value of $1965.2+1.0$ for the surface wamples and $2262.2 \pm 1.0$ for the deep water samples.
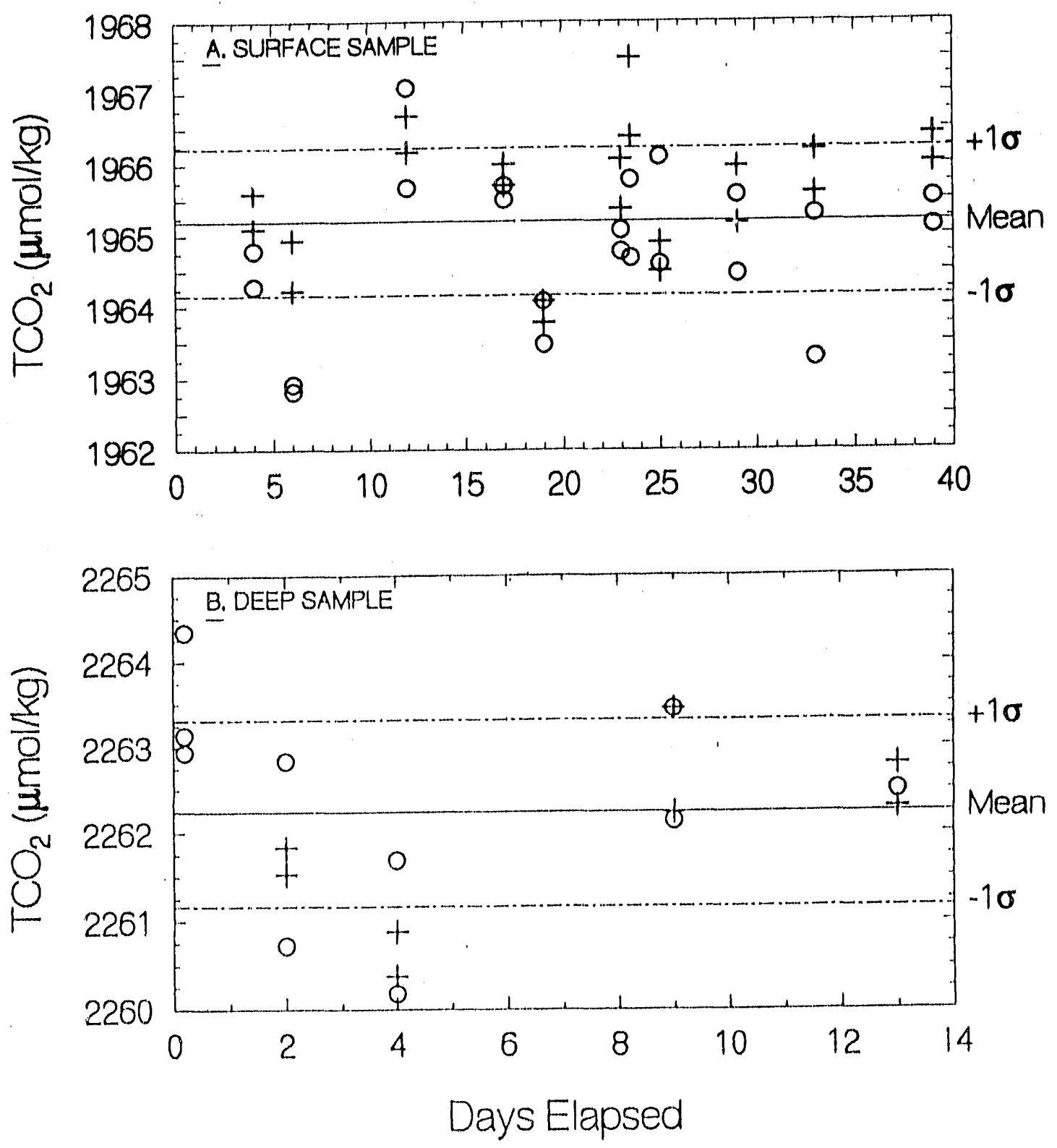

O Glass bottles + PET bottles 
Fig. 3 - A schematic diagram showing the gas-water equilibrator and gas chromatographic system for the measurement of $\mathrm{pCO}_{2}$ in discrete water samples. Two gas-water equilibration vessels are shown in this diagram. The electronic signals from the flame Inofzation detector are fed into and processed by an integrator (Shimadzu Chromatooac Model C-R6A) which is not shown.

\section{GC Oven}

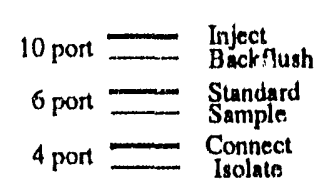

Standard gases aro 250,750 , and 1500 ipm CO2 in air.

-aluminum cylinders.

4 position distribution valve (8 position driver)
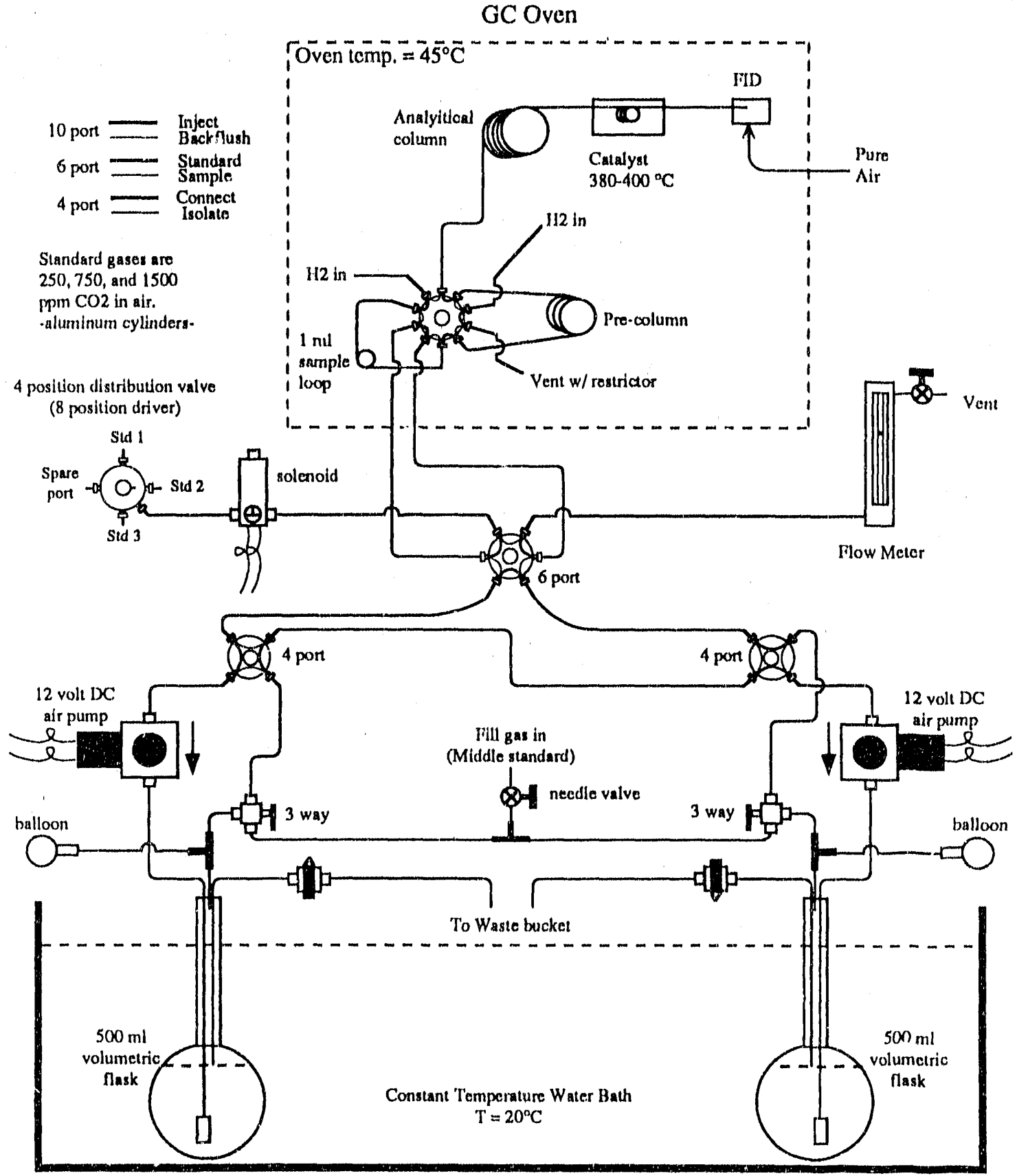
ples. Electrically driven Valco 4-port valves are used to isolate each of the equilibrators during the initial equilibration prior to analysis of the equilibrated air. Manually operated 2-way and 3-way Whitey valves allow part of the water in each equilibrator to be replaced with air of known initial $\mathrm{CO}_{2}$ concentration, to create the necessary headspace for equilibration. A drain line in each equilibrator insures the ratio of water to air in each equilibrator will be constant, allowing accurate corrections to be made for the effect of the perturbation of the sample seawater by the headspace air. Diaphragms (thin rubber balloons) are plumbed to each equilibrator to provide "soft walls" to the system, so that tire pressure in the equilibrators will be kept close to the ambient laboratory atmospheric pressure which is measured with a high precision electronic barometer. Since the partial pressure of $\mathrm{CO}_{2}$ is strongly affected by temperature changes, the equilibration flasks are kept immersed in a constant temperature water bath, held at a temperature of $20.00{ }^{\circ} \mathrm{C}$. An electrically driven Valco 6-port valve allows the entire equilibration system to be isolated, simultaneously connecting a calibration gas selection valve (also electrically driven Valco, Model 4SD, with 4 input ports but with an eight-position driver, so that all gas flows will be blocked at the four intermediate positions). A 2-way normally-closed Skinner solenoid valve on the output of the calibration selection valve allows the gas flows to be controlled by the system controller, and provides a necessary second means of stopping the flow of the calibration gases to prevent the accidental loss of calibration gases in the event of control malfunction.

The analysis of the $\mathrm{CO}_{2}$ in the equilibrated air or calibration gases is performed using a Shimadzu Mini-2, gas chromatograph, which is equipped with a flame ionization detector. A one-ml sample loop, a pre-column and an analytical column (both packed with Chromosorb 102 and 0.2 and 2.0 meters long respectively) are attached to an electrically driven Valco 10-port valve within th. 3 column oven of the gas chromatograph. Ultra-high purity hydrogen gas (electrolytically generated by an Aadco hydrogen generator and purified by means of diffusion through a palladium foil using an Aadco hydrogen purifier) serves as the carrier gas for the chromatographic separation of $\mathrm{CO}_{2}$ from the other components of the air. The use of hydrogen for carrier gas also allows the $\mathrm{CO}_{2}$ to be converted to methane in an attached catalytic converter prior to quantification by the flame ionization detector. Unlike the method described by Weiss (1981), our system uses a catalyst of ruthenium metal on Chromosorb W support and does not require a palladium pre-catalyst to remove oxygen from the carrier gas stream. Hydrocarbon-free air to support the combustion in the flame ionization detector is provided by means of a chromatographic air purifier (Aadco Model 737).

Integration of the output signal from the gas chromatograph and control of the entire equilibration and calibration procedure is provided by means of a Shimadzu Chromatopac (Model C-R6A) computing integrator. 
The analytical procedure is as follows. Prior to analysis, the sample flasks are brought to $20.00^{\circ} \mathrm{C}$ in the thermostated water bath, and about $45 \mathrm{ml}$ of water is displaced with air of known $\mathrm{CO}_{2}$ concentration. The air in the flasks and in the tubing connecting the flasks to the gas chromatograph sample loop is recirculated continuously for approximately 20 minutes, with the gas disperser about $1 \mathrm{~cm}$ below the water surface providing large contact area between water and air bubbles. Ai the end of the equilibration period, the circulation pump is switched off and the air pressure throughout the system is allowed to equalize. A $1-\mathrm{ml}$ aliquot of the equilibrated air is isolated from the equilibration subsystem and injected into the carrier gas stream of the gas chromatograph by cycling the gas sampling valve to which the sample loop is attached. After chromatographic separation, the $\mathrm{CO}_{2}$ is converted into methane and water vapor by reaction with the hydrogen carrier in the catalytic converter. The methane produced by this reaction is then measured with a precision of $\pm 0.05 \%$ (one standard deviation) by the flame ionization detector. The concentration of $\mathrm{CO}_{2}$ in the sample is determined by comparison with the peak areas of known amounts of $\mathrm{CO}_{2}$ from injections of three reference gas mixtures, which have been calibrated against the World Meteorological Organization standards of C. D. Keeling. The reference gas mixtures are injected into the gas chromatograph using the same sample loop as that used for the equilibrated air samples, and the pressure of the gas in the sample loop at the time of injection is determined by venting the loop to atmospheric pressure and measuring that pressure by means of a high-accuracy electronic barometer (Setra Systems, Inc., Model 270, accuracy \pm 0.3 millibars, calibration traceable to the NBS provided by the manufacturer). The sample loop is located within the wellcontrolled temperature environment of the column oven of the gas chromatograph, and hence all injections are made at constant temperature.

In order to demonstrate that the equilibrator yields an equilibrium $\mathrm{pCO}_{2}$ value and that use of gas bubbles does not affect the results, an experiment has been conducted. The equilibration vessel was first filled with a seawater sample which has a higher $\mathrm{pCO}_{2}$ than the carrier gas. The temperature of water was kept at $20.0^{\circ} \mathrm{C}$. While the water sample was gently stirred with a magnetic stirrer, the carrier gas was circulated through the equilibration vessel without bubbles (i.e. the gas disperser was pulled above the water). After 2 hours, a steady state value of 824.8 uatm was obtained. The water was then warmed by about a few degrees $\mathrm{C}$, so that $\mathrm{pCO}_{2}$ in the carrier gas was increased, while the amount of $\mathrm{CO}_{2}$ within the system remained unaltered. The water was then cooled to $20.0^{\circ} \mathrm{C}$ within about 10 minutes, while the $\mathrm{pCO}_{2}$ in the circulating carrier gas was monitored. $\mathrm{As} \mathrm{pCO}_{2}$ in the circulating gas decreased gradually over 2 to 4 hours of quiet stirring of water, a steady state value of 829.9 uatm was obtained, suggesting that the equilibrium yalue should lie between these two readings, 824.8 and 829.9 uatm or $827.4 \pm 2.5$ uatm. Next, the water was cooled by a few degrees $C$ in order to lower the $\mathrm{pCO}_{2}$ in the gas and then its temperature was restored to $20.0^{\circ} \mathrm{C}$ while circulating carrier gas was 
Fig. 4 - Test for the $\mathrm{CO}_{2}$ equilibration between air and seawater, and the effect of bubbles on equilibration. The equilibrium value is bracketed by the value of 824.8 and 829.9 uatm, which respectively represent steady state values approached from above and below after 2 hours of quiet stirring. The steady state value obtained after bubbling is 827.6 uatm, which agrees well with the mean of the quiet stirring values, 827.4 uatm.

\section{Approach to Equilibrium}

Qulet Stliring vs Bubbling

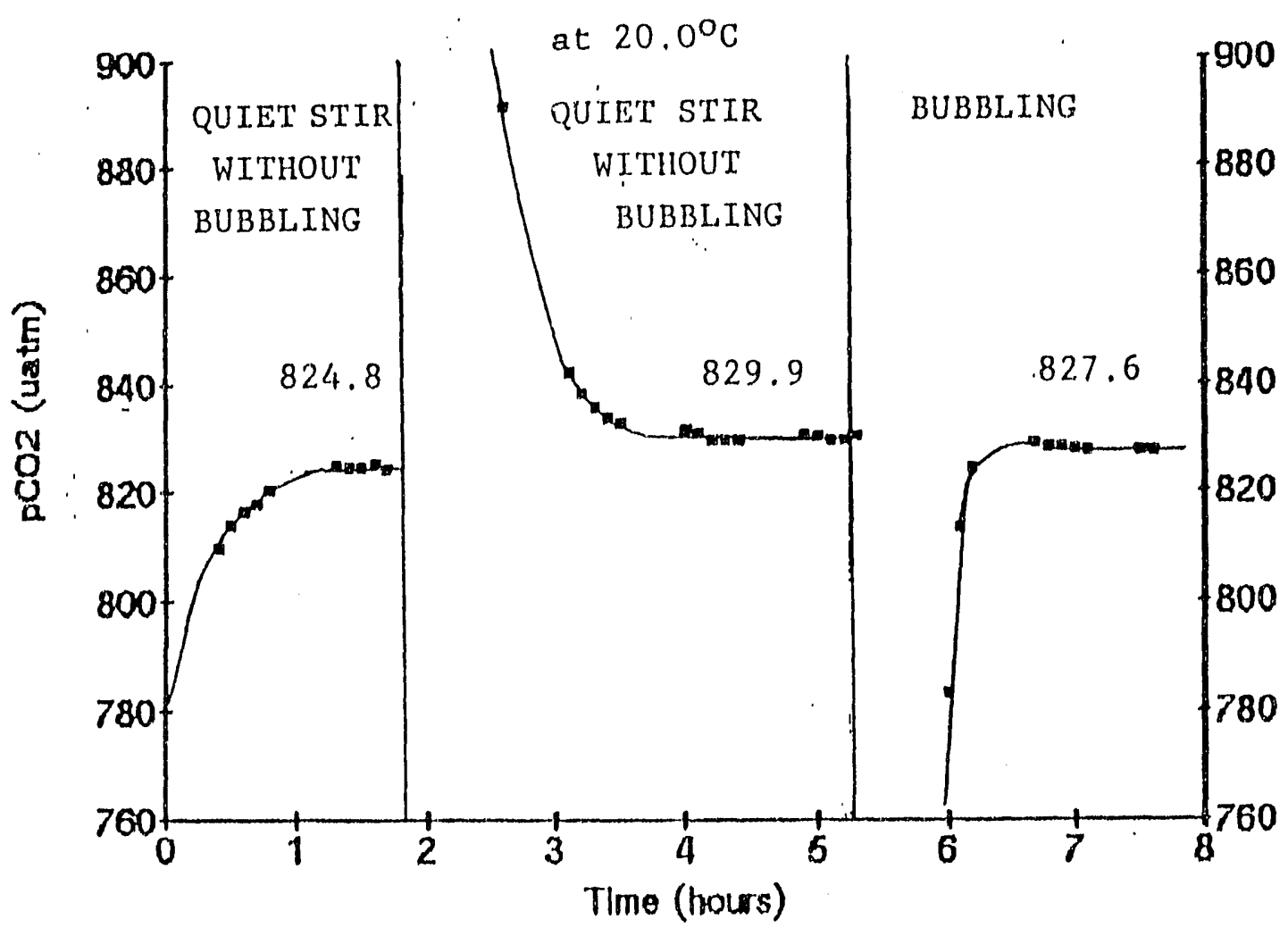


bubbled through the upper $1 \mathrm{~cm}$ of water column (i.e. by lowering the gas disperser head into the water). Fig. 4 shows that the bubbling process greatly enhances the rate of $\mathrm{CO}_{2}$ gas exchange between the air and water and yields a steady state value of $827.6 \mathrm{uatm}$. This value is consistent with the mean value obtained for the quiet equilibration (i.e. no bubbles) approached from high and low $\mathrm{pCO}_{2}$. Accordingly, the method used in this study appear to yield a thermodynamic equilibrium value without introducing systematic bias in the final composition of the equilibrated air.

The equilibrated air samples are saturated with water-vapor at the temperature of equilibration and have the same $\mathrm{pCO}_{2}$ as the water sample. By injecting the air aliquot without removing the water vapor, the partial pressure of $\mathrm{CO}_{2}$ is determined directly, without the need to know the water vapor pressure (Takahashi et al., 1982). It is necessary to know the pressure of equilibration, which is done by having the equilibrator flask always at atmospheric pressure. The atmospheric pressure is, in turn, measured with the electronic barometer at the time each equilibrated air sample is injected into the gas chromatograph. Corrections are required to account for the change in $\mathrm{pCO}_{2}$ of the sample water due to the transfer of $\mathrm{CO}_{2}$ to or from the water during equilibration with the recirculating air. The overall precision of the $\mathrm{pCO}_{2}$ measurement is estimated to be about \pm C..10\% based on the reproducibility of replicate equilibrations.

II-4) Determination of $\mathrm{pCO}_{2}$ in Air:

The air samples for $\mathrm{pCO}_{2}$ analysis were collected in a $50 \mathrm{ml}$ glass syringe equipped with a plastic shut-off valve. A small column of desiccant $\left(\mathrm{P}_{2} \mathrm{O}_{5}\right)$ was attached at the air intake for the removal of water vapor. The syringe was flushed with several volumes of air from a point at the ship's rail facing into the wind, and the valve was closed to isolate the final volume of air. The syringe was then connected to the sampling loop (about $1 \mathrm{ml}$ ) of the gas chromatograph, and the loop was flushed with at least $40 \mathrm{ml}$ of the sample air about 30 seconds before the loop contents were injected into the $\mathrm{GC}$ for analysis. The over-all precision for the atmospheric $\mathrm{CO}_{2}$ measurements, including the effects of the sampling and analytical procedures, has been estimated to be about $\pm 0.2 \mathrm{ppm} \mathrm{CO}_{2}$ mole fraction in dry air.

The $\mathrm{pCO}_{2}$ values in air have been computed assuming that the air is saturated with water vapor at the seawater temperature. The following equation was used for this purpose:

$$
\left(\mathrm{pCO}_{2}\right)_{\mathrm{air}}=\left(\mathrm{VCO}_{2}\right)_{\mathrm{air}} \cdot(\mathrm{Pb}-\mathrm{PW})
$$


where $\left(\mathrm{VCO}_{2}\right)_{\mathrm{alr}}$ is the mole fraction concentration of $\mathrm{CO}_{2}$ in dry air, $\mathrm{Pb}$ is the barometric pressure measured at each station and $P_{W}$ is the equilibrium water vapor pressure at sea surface temperature and salinity. The following empirical expression was used to compute the equilibrium water vapor pressure, Pw:

$$
\begin{aligned}
& \operatorname{Pw}(\mathrm{atm})=(1 / 760)\left[1-5.3684 \times 10^{-4} \cdot(\mathrm{Sal}-0.03)\right] . \\
& \operatorname{EXP}\left\{[0.0039476-(1 / \mathrm{TK})] / 1.8752 \times 10^{-4}\right\}
\end{aligned}
$$

where Sal is salinity in o/00 (PSU), and TK is the temperature in ${ }^{\circ} \mathrm{K}$.

Since the variability of atmospheric $\mathrm{CO}_{2}$ concentrations is expected to be small in the study area, only six determinations were made during the expedition. The measurements yield a mean atmospheric $\mathrm{CO}_{2}$ concentration of $350.0 \pm 1.5 \mathrm{ppm}$ (in mole fraction of $\mathrm{CO}_{2}$ in dry air). This mean value has been used to compute the atmospheric $\mathrm{pCO}_{2}$ and the sea-air $\mathrm{pCO}_{2}$ difference at each station. The measured atmospheric concentrations and computed atmospheric $\mathrm{pCO}_{2}$ values are listed in the Data Tables of this report.

II-7) Alkalinity:

The alkalinity of seawater has been computed using the observed values of $\mathrm{pCO}_{2}$, total $\mathrm{CO}_{2}$ concentration, phosphate concentration, temperature and salinity. For our computation, the total alkalinity (TALK) in seawater is defined by:

$T A L K=A c+A b+A s i+A p+A w$

where Ac = Carbonate alkalinity $=\left[\mathrm{HCO}_{3}\right]+2\left[\mathrm{CO}_{3}{ }^{-}\right]$

$\mathrm{Ab}=$ Borate alkalinity $=\left[\mathrm{H}_{2} \mathrm{BO}_{3}\right]$,

Asi = Silicate alkalinity $=\left[\mathrm{H}_{3} \mathrm{SiO}_{4}{ }^{-}\right]$,

Ap $\quad=$ Phosphate alkalinity $=\left[\mathrm{H}_{2} \mathrm{PO}_{4}\right]+2\left[\mathrm{HPO}_{4}^{-}\right]+3\left[\mathrm{PO}_{4}^{-3}\right]$,

Aw $=$ Water alkalinity $=[\mathrm{OH} \cdot]-\left[\mathrm{H}^{+}\right]$.

The total concentration of borate (TB) has been assumed to be proportional to salinity: $\mathrm{TB}(\mathrm{uM} / \mathrm{kg})=$ $410.6(\mathrm{Sal} / 35)$. The borate alkalinity ranges between about $40 \mathrm{ueq} / \mathrm{kg}$ for deep waters and $100 \mathrm{ueq} / \mathrm{kg}$ 
for surface waters. Since the silicate concentration in surface waters may be as high as $150 \mathrm{uM} / \mathrm{kg}$ in deep waters, the silicate alkalinity is as high as $6 \mathrm{ueq} / \mathrm{kg}$ for deep water but it is negligibly small for surface waters. The phosphate alkalinity ranges from $0.5 \mathrm{ueq} / \mathrm{kg}$ for surface waters to about 5 ueq/kg in deep waters. The following apparent dissociation constants of acid in seawater were used; Merhbach et al. (1973) for carbonic acid; Lyman (1956) for boric acid; Kester and Pytkowicz (1967) for phosphoric acid; Ingri (1959) for silicic acid; and Millero (1979) and Culberson and Pytkowicz (1973) for water. The expressions used to compute these constants as a function of temperature and salinity and the computational scheme are described in Peng et al. $\left(198^{\prime}\right)$ ).

\section{II-4) Measurements of Hydrographic Variables:}

The following hydrographic variables were measured by the staff of the Oceanographic Data Facility of the Scripps Institution of Oceanography and by the members of the Hydrographic Group from the Alfred Wagner Institute, Bremerhaven; temperature, pressure (depth), salinity, the concentrations of dissolved oxygen, nitrate, nitrite, phosphate and silica. The temperature and pressure readings of the CTD unit were corrected using 4 to 6 pairs of reversing thermometers, and the electrical conductivity readings were corrected using the salinity values determined aboard the ship for all of the $24 \mathrm{Ni}$ skin samplers. A Guildline salinometer and the Wormley Salinity Standards were used for the determination of salinity in the discrete water samples. The precision of measurements has been estimated to be $\pm 0.002 \circ \mathrm{C}$ for temperature and $\pm 0.002 \mathrm{o} / 00$ for salinity. The potential temperature $(\theta)$ and potential density $\left(\sigma_{\circ}, \sigma_{2}\right.$ and $\left.\sigma_{4}\right)$ values have been computed using the potential temperature algorithm of Fofonoff (1977), the International Equation of State of Seawater (Millero et al., 1980) and Bryden's (1973) formulation for the adiabatic temperature gradient.

The concentration of dissolved oxygen was determined using the Winkler titration method. For the conversion of volume to moles of oxygen, a molar volume at STP of 22.385 liter/mole (Kester, 1975 ) was used. The Apparent Oxygen Utilization (AOU) value was obtained by subtracting the measured value from the saturation value. The latter has been computed at the potential temperature of water and 1 atm total pressure using the following expression based on the data of Murray and Riley (1969):

$$
\begin{aligned}
\ln \left(\mathrm{O}_{2} \text { in } \mathrm{uM} / \mathrm{kg}\right)=-173.9894+255.5907(100 / \mathrm{TK}) \\
+146.4813 . \ln (\mathrm{TK} / 100)-22.2040(\mathrm{TK} / 100) \\
+ \text { Sal }\left[-0.037362+0.016504(\mathrm{TK} / 100)-0.0020564(\mathrm{TK} / 100)^{2}\right]
\end{aligned}
$$


where TK is temperature in ${ }^{\circ} \mathrm{K}$ and Sal is salinity in o/oo.

The concentrations of nitrate, nitrite, phosphate and silicate dissolved in the seawater samples were determined using the standard colorimetric methods with an "Auto-Analyser" generally within 6 hours of collection. The water samples were kept in a refrigerator at about $4^{\circ} \mathrm{C}$ during the storage period.

All the concentration values are expressed in "per kg of seawater" units, although analytical samples were isolated by volumetric means. For the conversion from the volume to the mass of seawater sample, the density of each water sample was computed with the International Equation of Sate for seawater (Millero et al., 1980) using the measured salinity and the temperature at which the volumetric measurement was made. 


\section{DISTRIBUTION OF OCEANOGRAPHIC PROPERTIES}

III-1) Distribution of Properties in Surface Waters:

The geographic distribution of temperature, salinity, $\mathrm{pCO}_{2}$, sea-air $\mathrm{pCO}_{2}$ difference $\left(\Delta \mathrm{pCO}_{2}\right)$, $\mathrm{AOU}$ and the concentrations of dissolved oxygen, total $\mathrm{CO}_{2}$, nitrate, phosphate and silicate in surface water is shown in Figs. 5, 6 and 7. Each of these properties is plotted along three sections: the Drake Passage (WOCE A-21), the northern Weddell Sea and the Capetown-Weddell (WOCE A-12) sections. The first and third sections are shown as a function of latitude and the second section is shown as a function of longitude.

Across the Drake Passage (Fig. 5), the surface water temperature increases northward from about $1.5^{\circ} \mathrm{C}$ at $63^{\circ} \mathrm{S}$ to about $10^{\circ} \mathrm{C}$ at $55.5^{\circ} \mathrm{S}$, while the salinity remains nearly constant at about 33.9 o/oo. On the other hand, all other properties tend to decrease northward. The $\mathrm{pCO}_{2}$ data show that the surface water is undersaturated with respect to atmospheric $\mathrm{CO}_{2}$, with an exception of the southernmost area south of about $62.5^{\circ} \mathrm{S}$, where the water is slightly supersaturated. The AOU values indicate that the surface water is supersaturated with respect to atmospheric oxygen by about 3 to $6 \%$ (or 10 to $20 \mathrm{uM} / \mathrm{kg}$; with an exception of the southernmost station $\left(62.8^{\circ} \mathrm{S}\right)$, where it is undersaturated by about $20 \mathrm{uM} / \mathrm{kg}$. A major feature observed is that the silicate concentration decreases rapidly northward from about $45 \mathrm{uM} / \mathrm{kg}$ at $63^{\circ} \mathrm{S}$ to about $1.5 \mathrm{uM} / \mathrm{kg}$ at about $61^{\circ} \mathrm{S}$ and remains at this low value in surface waters north of $61^{\circ} \mathrm{S}$ where the temperature exceeds $5^{\circ} \mathrm{C}$. On the other hand, the concentrations of nitrate, phosphate, $\mathrm{CO}_{2}$ and oxygen exhibit only a modest northward decrease across the Drake Passage.

The northern Weddell Sea section (Fig. 6) represents nearly a zonal section $\left(58^{\circ} \mathrm{S}-60^{\circ} \mathrm{S}\right)$ along the northern margin of the Weddell Sea with an exception of 4 stations located between $35^{\circ} \mathrm{W}$ and $40^{\circ} \mathrm{W}$ (Stations 128 through 131) deviating southward into the Weddell Sea. Along this section, the surface water temperature and salinity are nearly constant at about $2^{\circ} \mathrm{C}$ and $33.6 \mathrm{o} / 00$ respectively. The water along this section is undersaturated with respect to atmospheric $\mathrm{CO}_{2}$ by 25 to 100 uatm or about 50 uatm on the average. It is supersaturated with respect to atmospheric oxygen by as much as 7 $\%$ (or $25 \mathrm{uM} / \mathrm{kg}$ ) near $45^{\circ} \mathrm{W}$ and $61^{\circ} \mathrm{S}$, and it becomes closer to saturation eastward becoming nearly saturated or slightly undersaturated east of about $25^{\circ} \mathrm{W}$ (and $58^{\circ} \mathrm{S}$ ). A major change in the silicate concentration occurs near $58^{\circ} \mathrm{S}$ and $23^{\circ} \mathrm{W}$. The waters west of this location show silicate concentrations as high as $70 \mathrm{uM} / \mathrm{kg}$, whereas those east of $25^{\circ} \mathrm{W}$ contain less than $20 \mathrm{uM} / \mathrm{kg}$. On the other hand, the nitrate and phosphate concentrations change little along this section and remain nearly constant at about $20 \mathrm{uM} / \mathrm{kg}$ and $1.3 \mathrm{uM} / \mathrm{kg}$ respectively. 


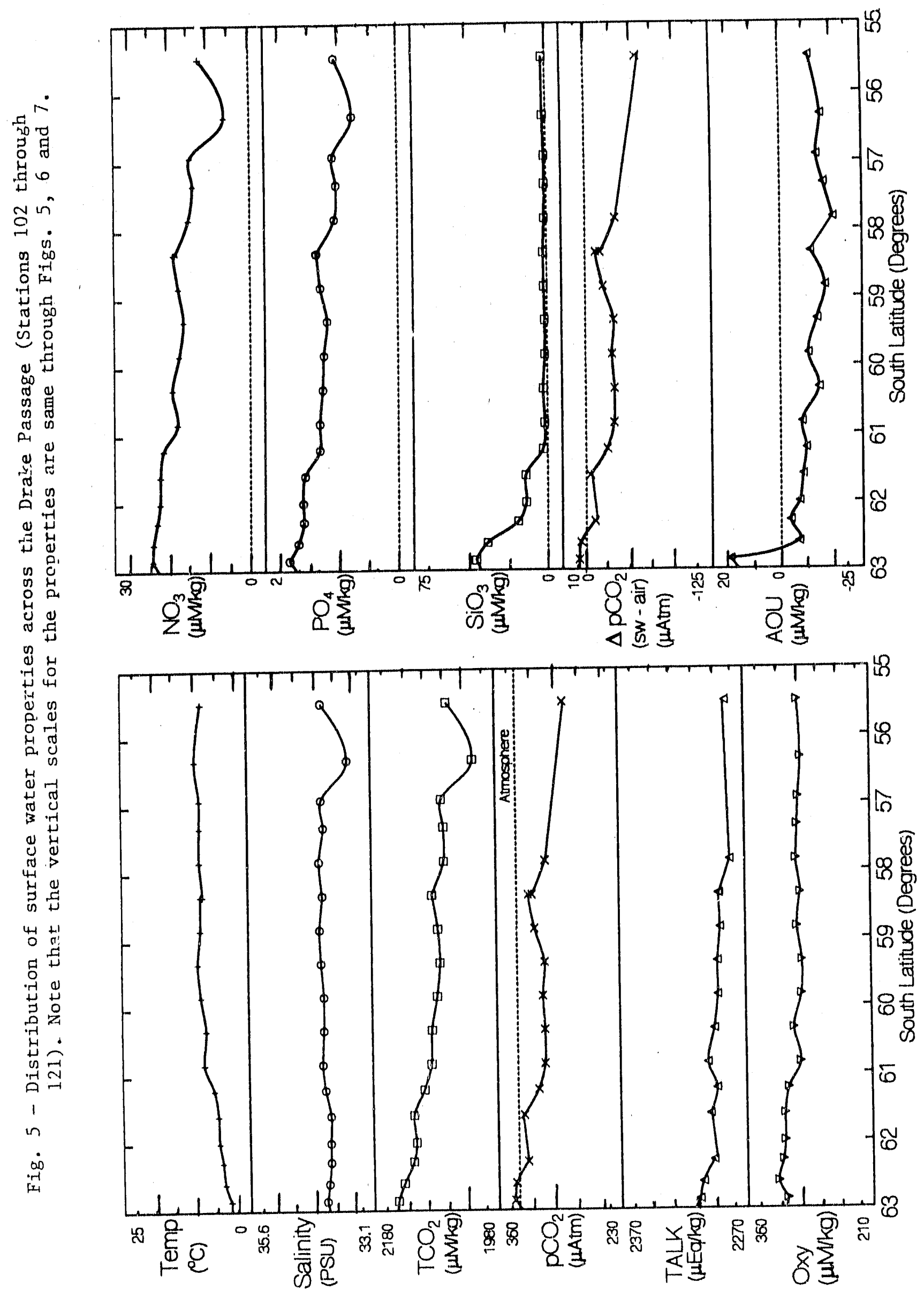




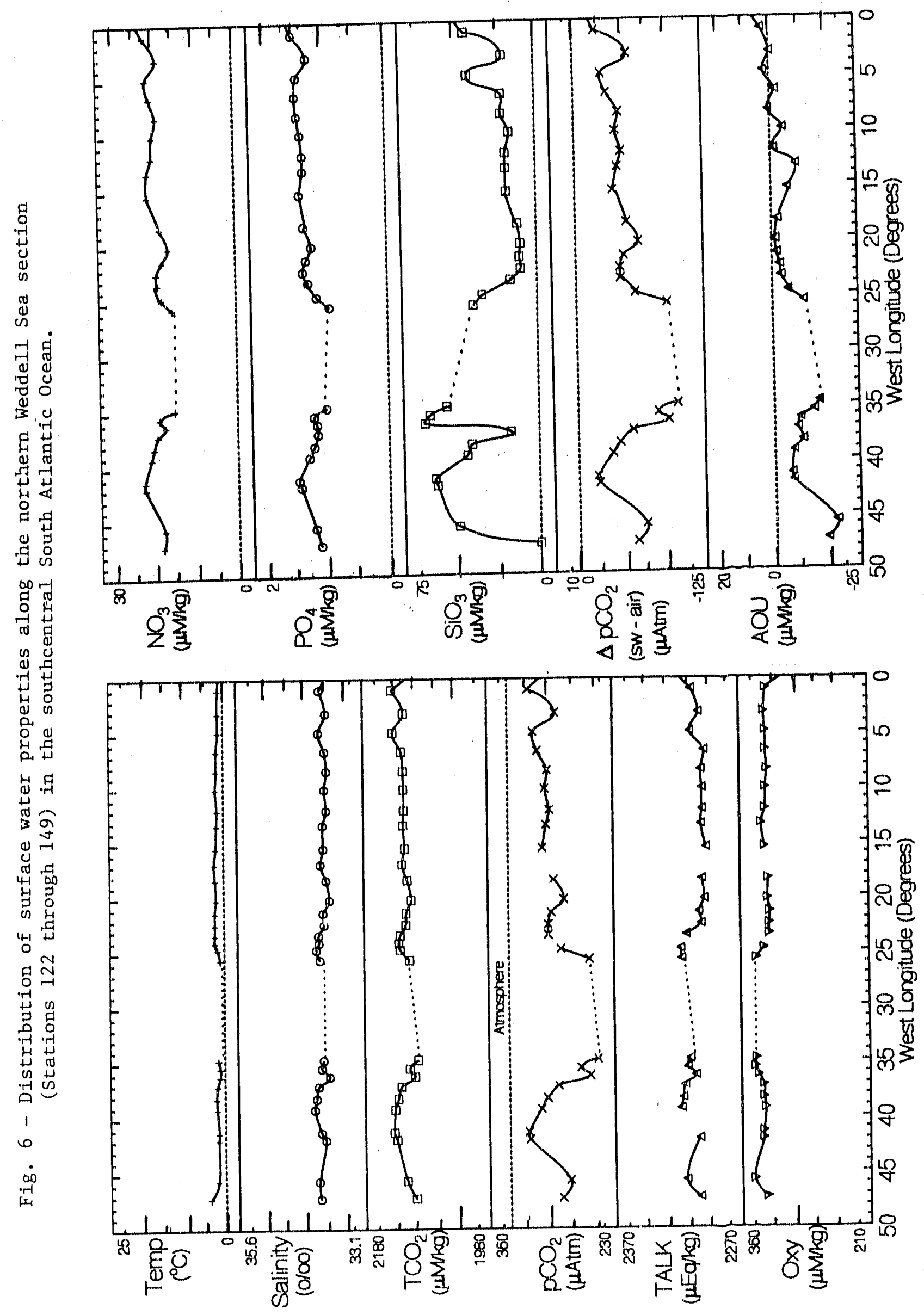


Along the Capetown-Weddell section (Fig. 7), four types of waters marked by three major boundaries were traversed. South of about $53^{\circ} \mathrm{S}$, the temperature and salinity are uniformly low at about $2{ }^{\circ} \mathrm{C}$ and $33.8 \mathrm{o} / 00$, whereas the concentrations of total $\mathrm{CO}_{2}$, oxygen, nitrate, phosphate and silica are uniformly high. The surface water is slightly undersaturated with respect to both atmospheric oxygen ( $\mathrm{AOU} \sim+3 \mathrm{uM} / \mathrm{kg}$ ) and $\mathrm{CO}_{2}\left(\Delta \mathrm{pCO}_{2} \sim-10 \mathrm{uatm}\right)$. From $53^{\circ} \mathrm{S}$ to $49^{\circ} \mathrm{S}$, the temperature increases from 2 to $7^{\circ} \mathrm{C}$, while all other properties decrease: total $\mathrm{CO}_{2}$ concentration from 2160 to 2100 $\mathrm{uM} / \mathrm{kg}$, oxygen concentration from 340 to $315 \mathrm{uM} / \mathrm{kg}$, nitrate concentration from 25 to $20 \mathrm{uM} / \mathrm{kg}$, phospliate concentration from 1.7 to $1.5 \mathrm{uM} / \mathrm{kg}$, silica concentration from 45 to $2 \mathrm{uM} / \mathrm{kg}$ and AOU from 0 to $-5 \mathrm{uM} / \mathrm{kg}$. North of $49^{\circ} \mathrm{S}$, where the water temperature exceeds $7^{\circ} \mathrm{C}$, the concentration of silica remains nearly zero. Between $49^{\circ} \mathrm{S}$ and $42^{\circ} \mathrm{S}$, the temperature continues to increase from about 7 to $11^{\circ} \mathrm{C}$, while other properties continue to decrease northward. North of $43^{\circ} \mathrm{S}$, the temperature, salinity and alkalinity increase abruptly from about 11 to $17^{\circ} \mathrm{C}$ and from about 34.0 to $35.0 \mathrm{o} / 00$, indicating the Subtropical convergence. At the same time, the concentrations of nitrate and phosphate decrease respectively from about 10 to $0 \mathrm{uM} / \mathrm{kg}$ and from 1.0 to $0.1 \mathrm{uM} / \mathrm{kg}$. South of the convergence, between $43^{\circ} \mathrm{S}$ and $35^{\circ} \mathrm{S}$, the surface water is undersaturated with respect to atmospheric $\mathrm{CO}_{2}$ by about 50 uatm whereas it is supersaturated with respect to oxygen by about $10 \mathrm{uM} / \mathrm{kg}$. 


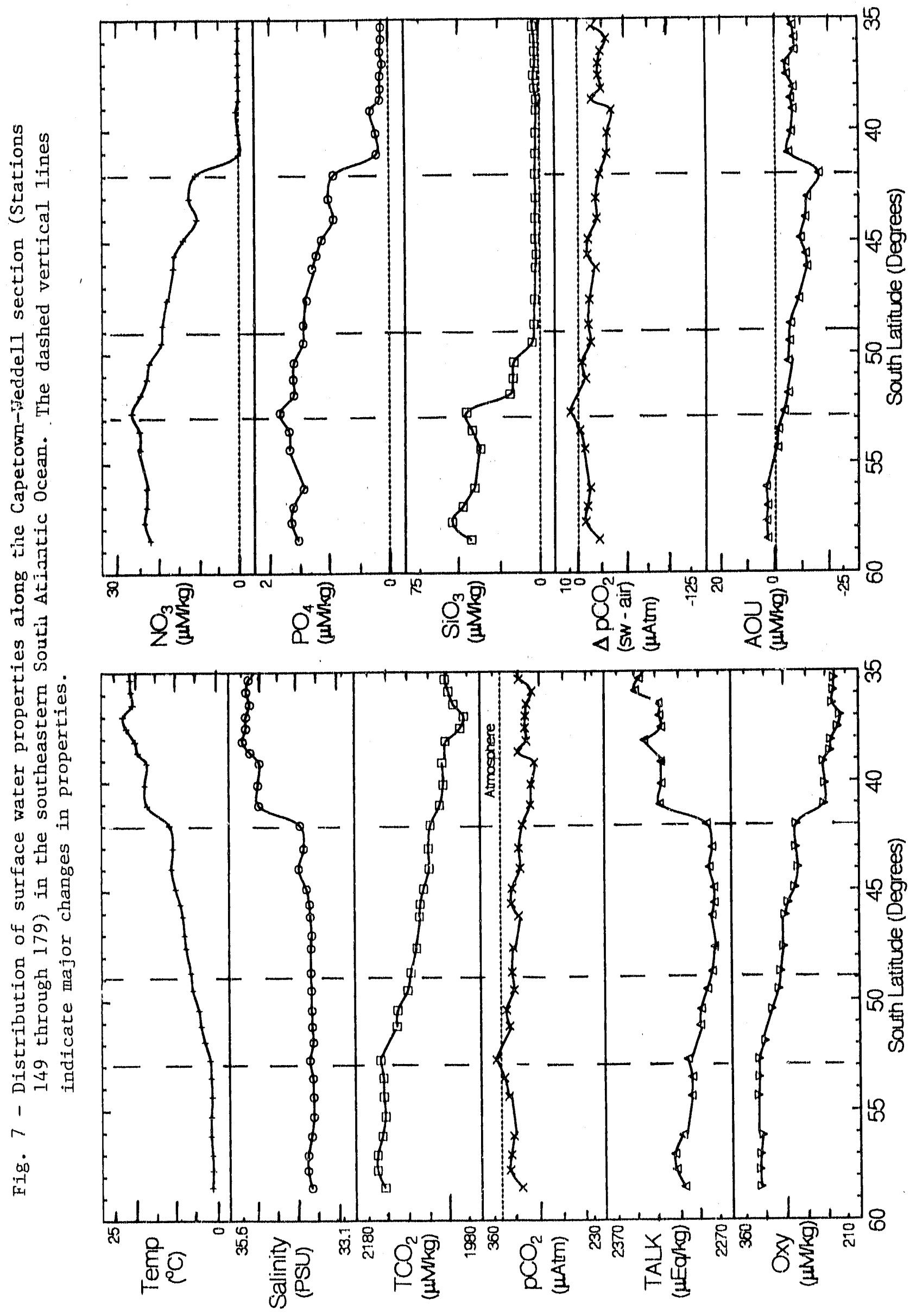


III-2) The Drake Passage (N-S) Section (Stations 102-121):

Contoured sections across the Drake Passage for the following properties are shown below: potential temperature, salinity, potential density at $2000 \mathrm{db}$, the apparent oxygen utilization (AOU) and the concen- trations of total $\mathrm{CO}_{2}$, dissolved oxygen, nitrate, phosphate and silica. Since $\mathrm{pCO}_{2}$ values were obtained at only one station, no section for $\mathrm{pCO}_{2}$ is presented. All the sections shown in Fig. 8 through Fig. 61 are presented with the full $X$-axis span equaling to 800 nautical miles.

Fig. 8 shows potential temperature distribution across the passage. The temperature ranges from about $0.2^{\circ} \mathrm{C}$ at about 4000 meters deep in the southern extreme to about $8{ }^{\circ} \mathrm{C}$ in surface waters near the coast of South America. Isotherms dip northward and show vertically coherent wavy pattern. This suggests that several bands of water flow zonally through the Drake Passage (i. e. right angles to the section).

Fig, 9 shows that the ischaline contours also are tilted to the north with vertically coherent wavy patterns above about 2000 meters deep. A salinity maximum which may be defined with the $34.73 \mathrm{o} / 00$ contours coincides with the 1.0 and $1.5^{\circ} \mathrm{C}$ isotherms (Fig. 8) and $190 \sim 200 \mathrm{uM} / \mathrm{kg}$ contours for oxygen (Fig, 13). This salinity maximum represents the Circumpolar Deep Water which has temperatures of $0.9 \sim 1.4^{\circ} \mathrm{C}$ with salinities of $34.68 \sim 34.72 \mathrm{o} / 00$ and is commonly found in a depth range of $300 \sim 950$ meters in the Southern Ocean (Jacobs et al., 1985). The potential temperature-salinity relationships observed in this section are shown in Fig. 10. There is a minor salinity maximum which is centered around 3500 meters and outlined with the $34.70 \%$ oo isohalines in the sc dthern extreme of this section. Below the Circumpolar Deep Water lies a colder water layer $\left(0.2 \sim 1.0^{\circ} \mathrm{C}\right)$ with a salinity of about $34.70 \mathrm{o} / 00$. This has been identified as the Southeast Pacific Basin Deep Water (SPDW) (Gordon, 1971-a), and is clearly depicted as a kink point at about $2.0^{\circ} \mathrm{C}$ and $34.71 \mathrm{o} / 00$ on the $\theta-S$ plot in Fig. 10. Below the depths exceeding about 3500 meters at the three southernmost stations, another colder and less saline water mass $(34.70 \sim 34.685 \mathrm{o} / \mathrm{oo})$ is present (see Figs. 8, 9 and 10). This represents the Bottom Water of the Southeast Pacific Basin (SPBW) (Gordon, 1971-a).

The distribution of the total $\mathrm{CO}_{2}$ and oxygen concentrations (Figs. 12, 13 and 14) show additional features: $\mathrm{a} \mathrm{CO}_{2}$ maximum layer (outlined by the 2260 and $2270 \mathrm{uM} / \mathrm{kg}$ contours in Fig. 12) and an oxygen minimum layer (outlined by the 170 and $180 \mathrm{uM} / \mathrm{kg}$ contours in Fig. 12). Both of these features are located above the salinity maximum layer of the Circumpolar Deep Water and are centered around 2000 meters deep against the continental slope of the South America. They slope upward to the south and reach at a depth of about 500 meters near the Antarctic Peninsula. These features thus observed for the oxygen distribution (Fig. 13) are consistent with that obtained by Gordon and Moli- 


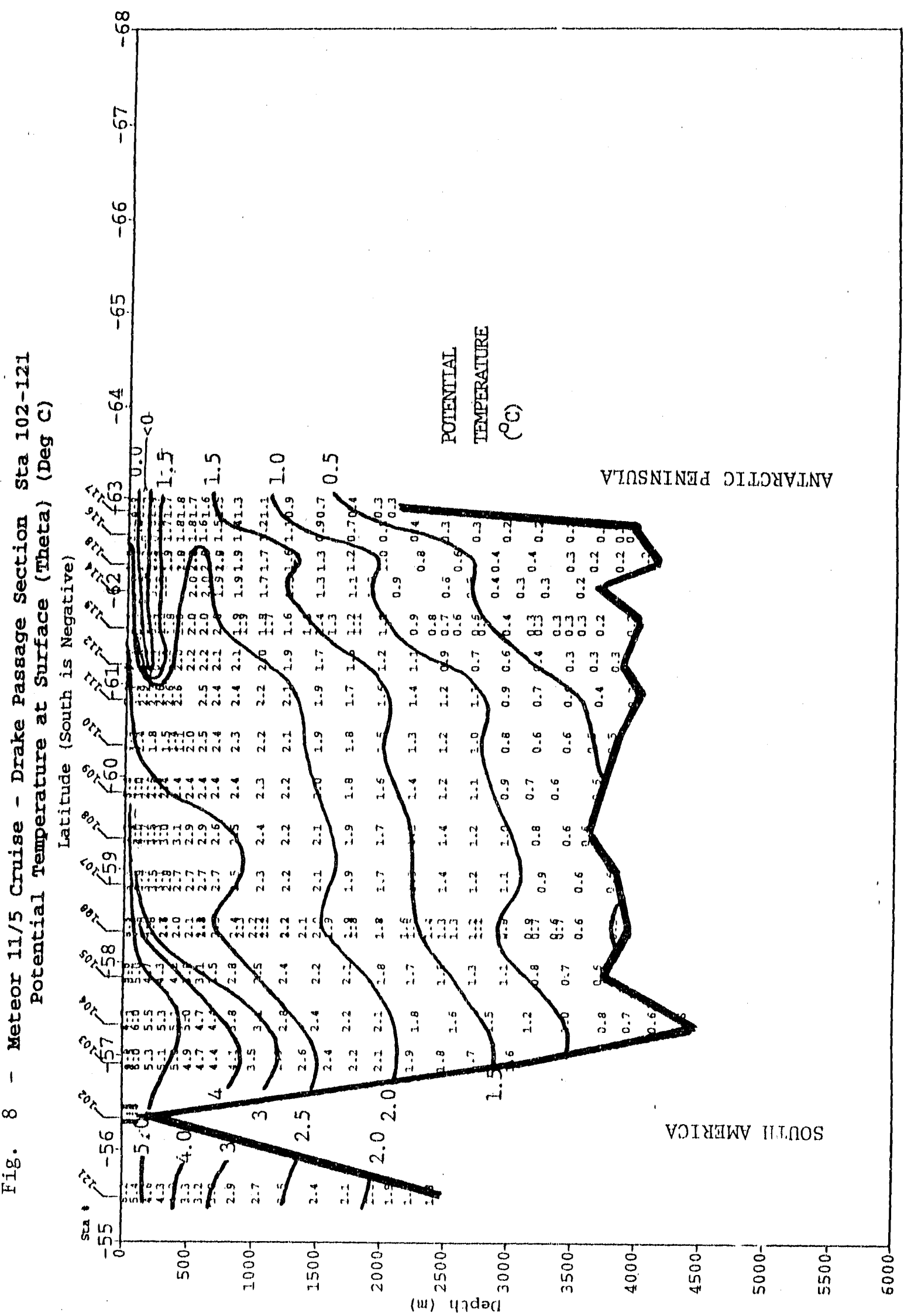




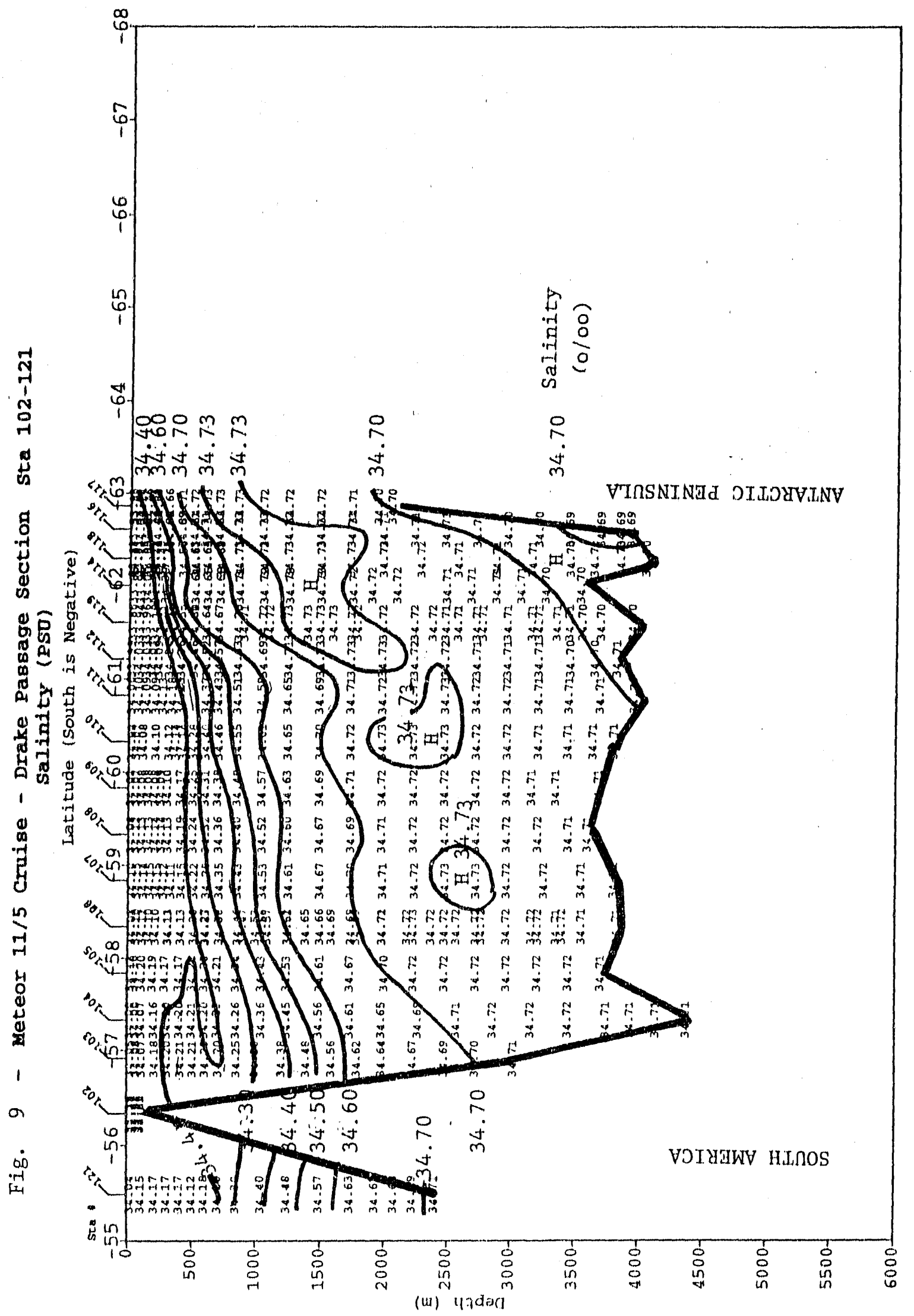

然 
Fig. 10 - Potential temperature-salinity relationships observed in the Drake Passage section. CPDW = Circumpolar Deep Water.

F/S Meteor Cruise 11/5

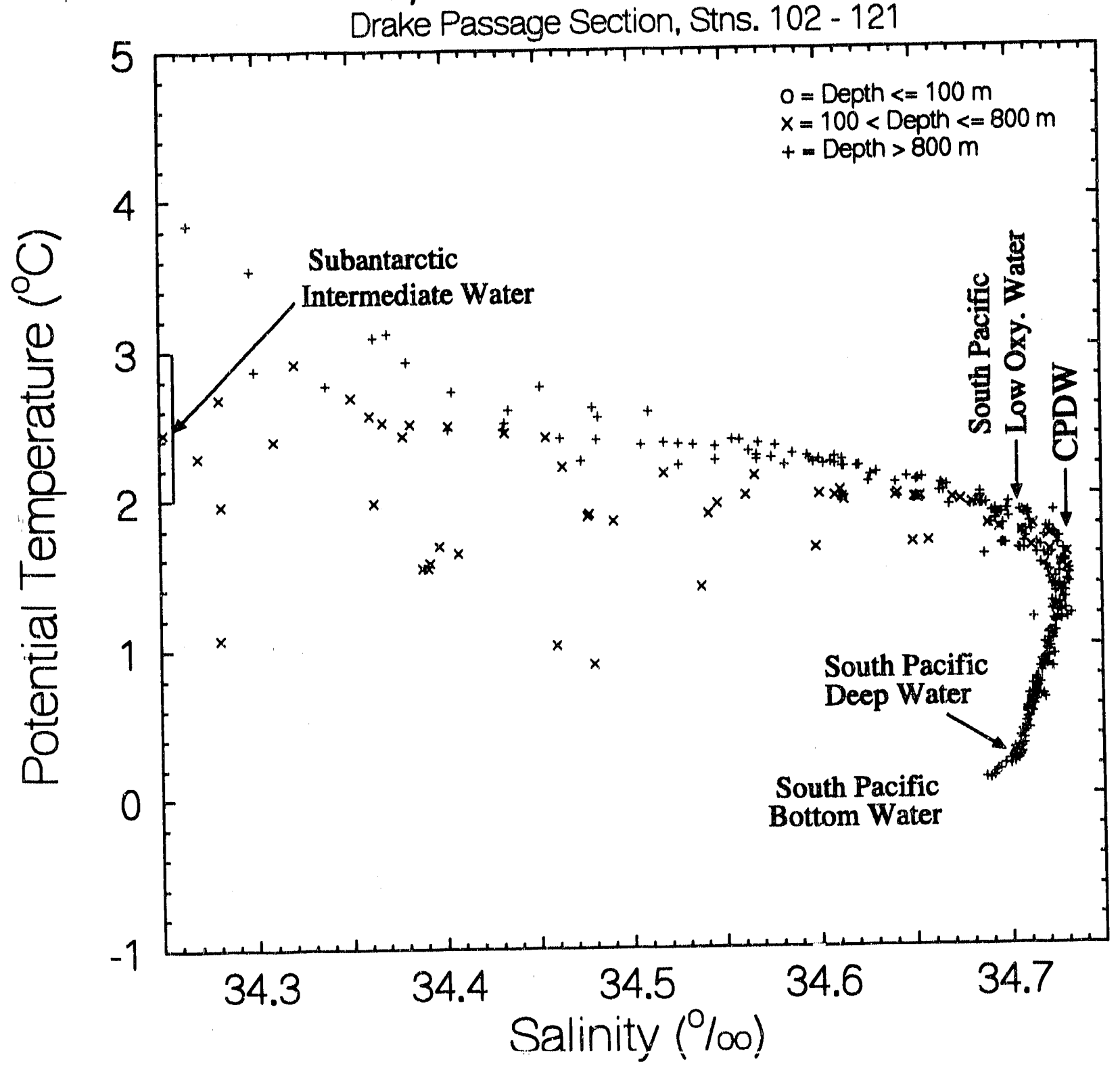




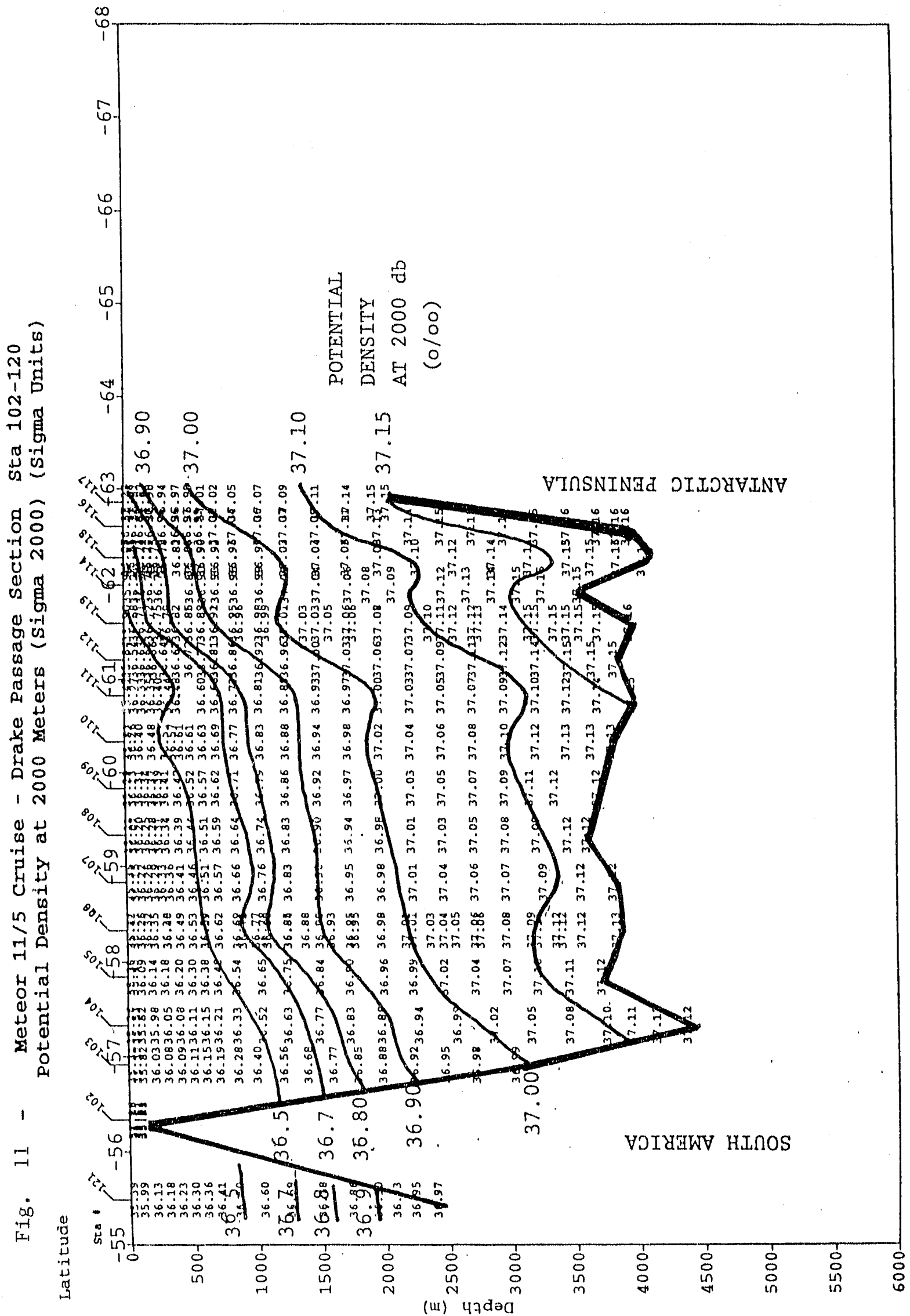




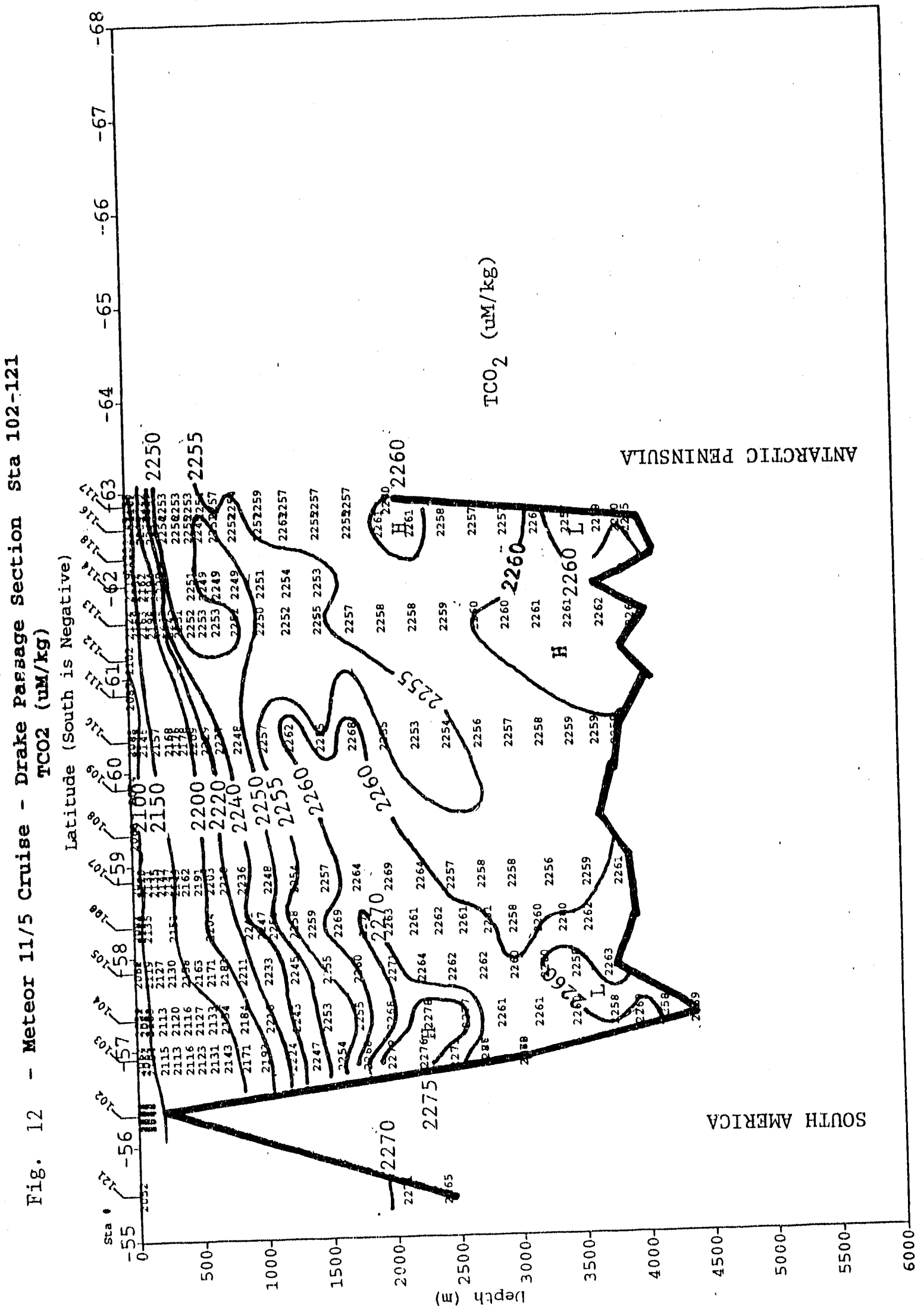




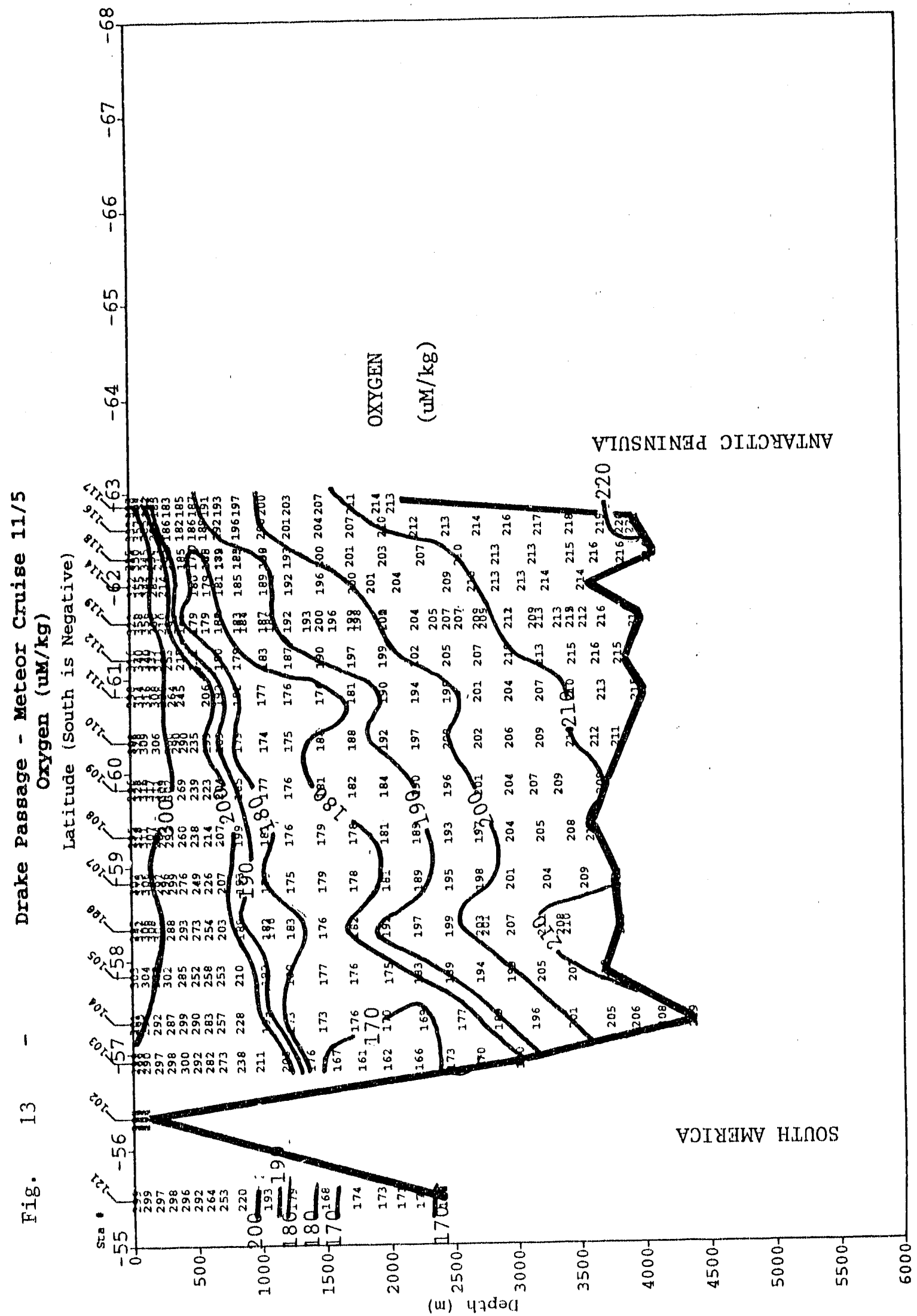


TABLE - 1 Summary of the physical and chemical characteristics of various water masses observed during the Meteor 11/5 expedition in the South Atlantic and northern Weddell Sea areas. The values represent extreme values observed during the expedition, but do not uecessarily indicate the values for the "pure" end members of water mass. CPDW = Circumpolar Decp Water; SPLOW = South Pacific Low Oxygen Water; SPDW = South Pacific Deep Water; SPBW = South Pacific Bottom Water. (+) and (-) signs indicate that the values listed comprise a local maximum and minimum respecitvely.

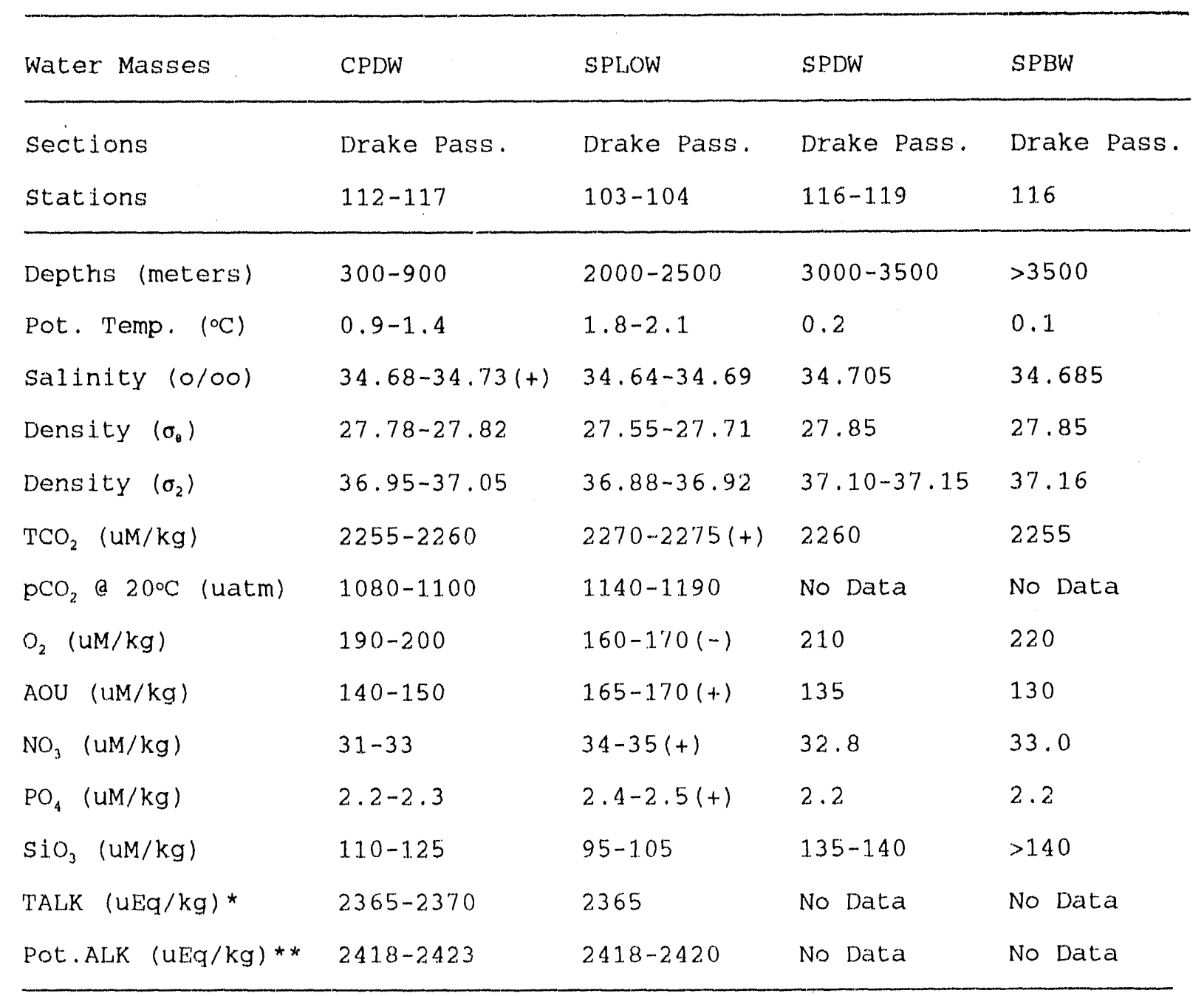

* Total alkalinity (TALK) values computed using the total $\mathrm{CO}_{2}$ concentration and $\mathrm{pCO}_{2}$ a $20^{\circ} \mathrm{C}$ data at observed salinities.

**/ Potentia] alkalinity (Pot. ALK) computed as [(TALK) $\left.+\left(\mathrm{NO}_{3}^{-}\right)\right]$and normalized to a salinity of $35.000 / 00$. 
nelli (1982) (see their Plate 185). Based upon the geometry of this oxygen minimum $/ \mathrm{CO}_{2}$ maximum zone, it appears that this water was originated in the southeastern Pacific by the oxidation of falling biogenic debris and advected southward along the South American continental slope into the Drake Passage.

In the southern half of the Passage, the oxygen concentration increases monotonically with depth reaching $220 \mathrm{uM} / \mathrm{kg}$ near the bottom (Fig. 13). The AOU value decreases to $130 \mathrm{uM} / \mathrm{kg}$ (Fig. 14) at the southern extreme indicating influx into the Drake Passage of a relatively young water mass present near the bottom of the Southeast Pacific Basin.

The sections for nitrate and phosphate (Figs, 15 and 16) do not add further information to those already discussed above. This is due mainly to much smaller dynamic ranges available for these two properties: the nitrate and phosphate concentrations change only from 30 to $33 \mathrm{uM} / \mathrm{kg}$ and from 2.2 to $2.4 \mathrm{uM} / \mathrm{kg}$ respectively, while the estimated precision of these measurements for the Drake Passage section is about $\pm 0.5 \mathrm{uM} / \mathrm{kg}$ for nitrate and $\pm 0.05 \mathrm{uM} / \mathrm{kg}$ for phosphate. Therefore, the small variations observed in deep waters below about 2000 meters do not appear to be significant, and the contour lines presented for the depths below about 2000 meters in Figs. 15 and 16 should not be reliable. On the other hand, the silica concentration (Fig. 17) varies from about 20 to $140 \mathrm{uM} / \mathrm{kg}$. The lowest values are found in the shallow northernmost waters and the highest values located in the south ernmost area near the sea floor. Its distribution parallels with that of potential temperature and exhibits the vertically coherent wavy patterns. The silica concentration ranges from about 80 to $100 \mathrm{uM} / \mathrm{kg}$ for the oxygen minimum layer and from about 105 to $120 \mathrm{uM} / \mathrm{kg}$ for the salinity maximum Circumpolar Deep Water. The characteristic chemical properties for the three water masses found in this section are summarized in Table 1. 


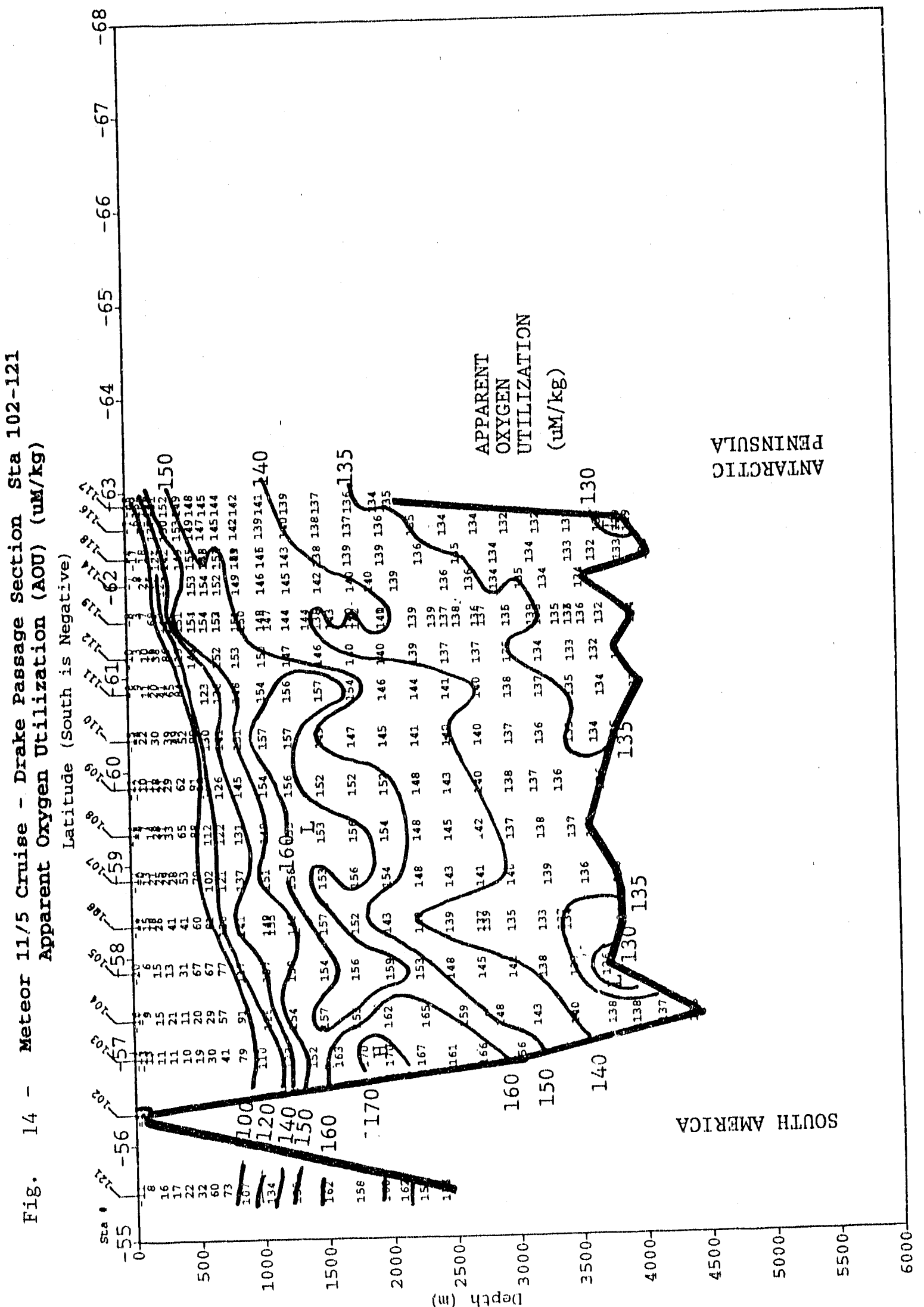




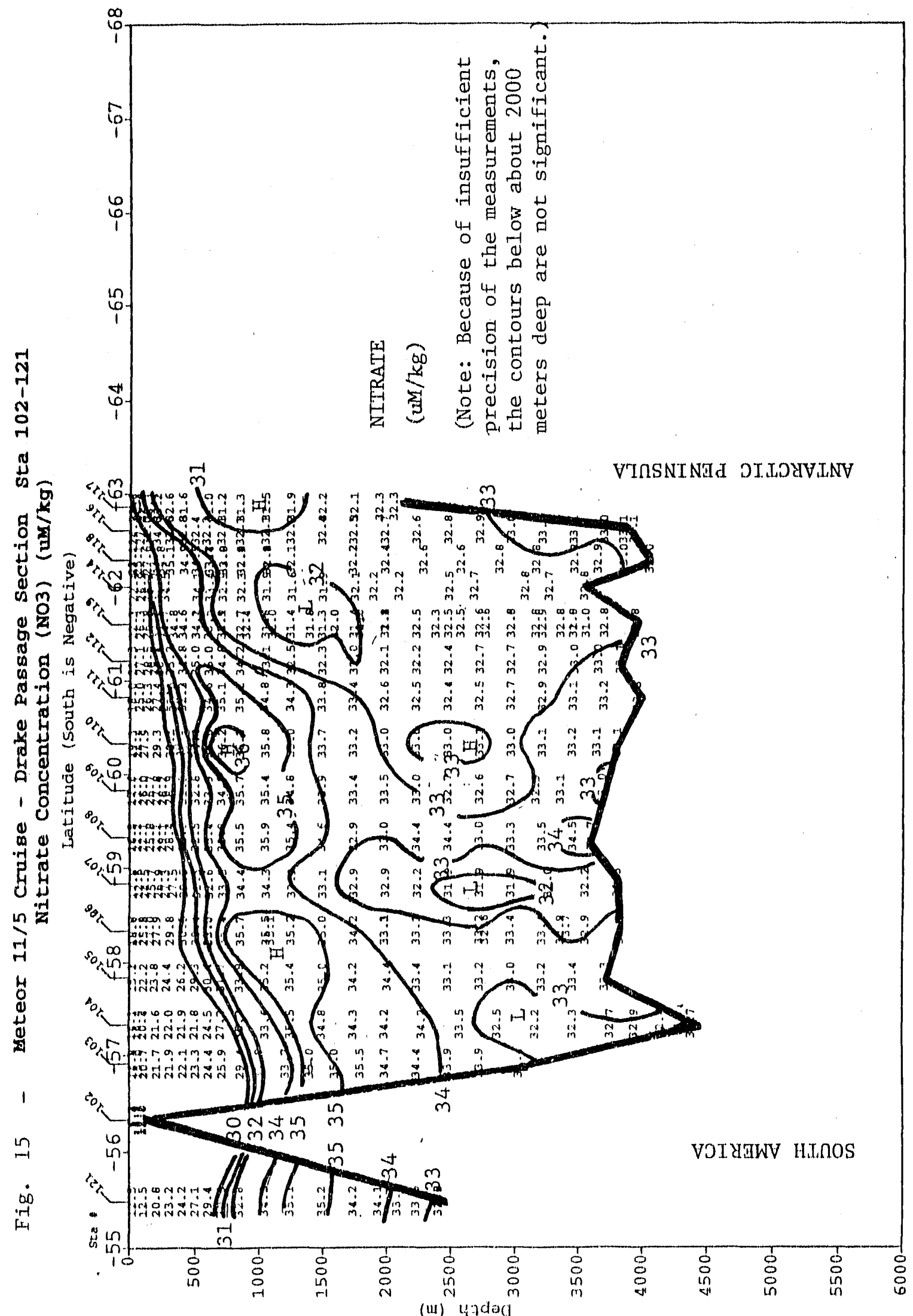




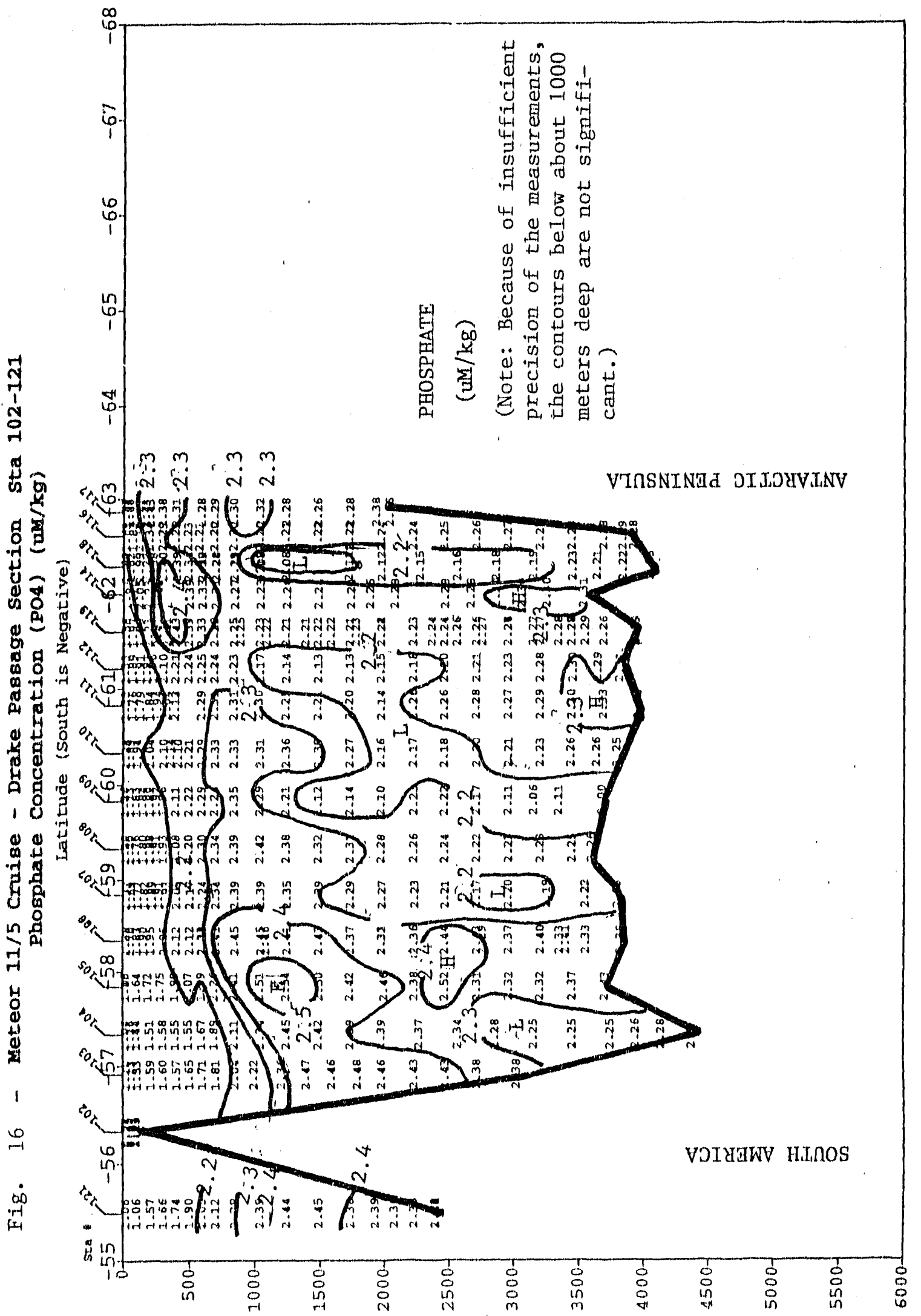

(I4) 4ว 


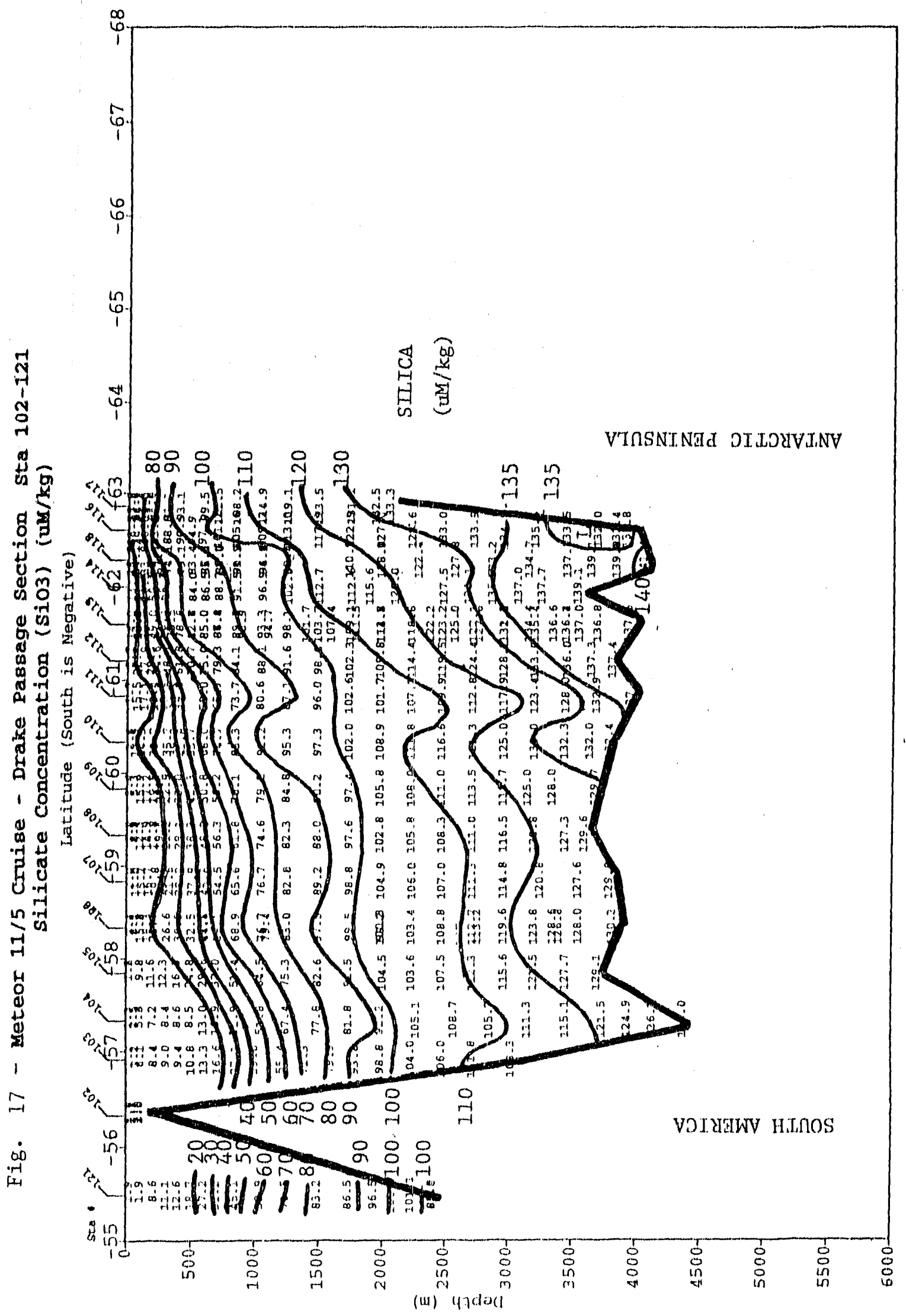


III-3) The Northern Weddell Sea Section (Stations 122-131);

This section runs more or less NW-SE direction cutting across the northern edge of the eastward out-flow of the cyclonic Weddell gyre. The $\chi$-axis scale has a full span of 800 nautical miles which is same as the Drake Passage section. Since the nitrate data at Stations 122 through 125 appear to be in error, no contour lines for nitrate are presented for the western half of this section (Fig. 26).

Fing. 18 shows the distribution of potential temperature. While the lowest temperature observed across the Drake Passage section is $0.2^{\circ} \mathrm{C}$, temperatures as low as $-0.88^{\circ} \mathrm{C}$ are observed in this section. The salinities in these cold waters below $\left({ }^{\circ} \mathrm{C}\right.$ range between 34.66 and $34.64 \mathrm{o} / 00$ (Fig, 19) and are much lower than those $(34.70 \sim 34.73 \mathrm{o} / \mathrm{o})$ ) found in the deep waters in the Drake Passage section, indicating a dominating influence of the Weddell Sea Bottom Water (Carmack and Foster, 1975) in the sub-zero temperature regime. The potential temperature-salinity relationships observed in this section are shown in Fig. 20. At the southernmost station (Stn. 131, located at 63'10'S and $\left.34^{\circ} 45^{\prime} \mathrm{W}\right)$ ), both the temperature and salinity decrease to $-0.88^{\circ} \mathrm{C}$ and $34.64 \mathrm{o} / 00$ toward the sea floor about 5200 meters deep. At this station, the total $\mathrm{CO}_{2}$ concentration and $\mathrm{pCO}_{2}$ (at $20^{\circ} \mathrm{C}$ ) decrease to $2240 \mathrm{uM} / \mathrm{kg}$ (Fig. 22) and $1025 \mathrm{uatm}$ (Fig. 23) near the bottom, while the oxygen concentration increases to about $260 \mathrm{uM} / \mathrm{kg}$ (Fig. 24) and AOU decreases to about $100 \mathrm{uM} / \mathrm{kg}$ (Fig. 25). The concentrations of nitrate, phosphate and silica also decrease to about $32 \mathrm{uM} / \mathrm{kg}, 2.25 \mathrm{uM} / \mathrm{kg}$ and 113 $\mathrm{uM} / \mathrm{kg}$ respectively (Figs, 26 and 27). All these values indicate the presence of recently ventilated water in the abyssal water in the Weddell Sea. The chemical properties of the Weddell Sea Bottom Water (WSBW) as observed in this section are listed in Table 2.

In the northern (or western) extreme of this section near Station 122, two layers of warmer $\left(0.5 \sim 1.0^{\circ} \mathrm{C}\right)$ and more saline $(34.67 \sim 34.70 \mathrm{o} / 00)$ waters are found between about 300 and 2500 meters (Figs. 18 and 19). The salinity maxima are centered around about 700 and 1800 meters respectively and these appear to represent the upper and lower Circumpolar Deep Waters, which were observed by Reid et al. (1977) along the Scotia arc. These layers have $\sigma_{2}$ densities of about 36.95 and 37.10 respectively, but cannot be clearly resolved using other properties than salinity, although a weak maximum in AOU and a weak minimum in oxygen appear to be associated with the upper layer and a weak $\mathrm{TCO}_{2}$ minimum appears in between these two layers.

In the southern half of this section (Stations 126 through 131), a layer of cooler $\left(0 \sim 0.5^{\circ} \mathrm{C}\right)$ water with similar salinities is present in a depth range centered around 500 meters between 300 and 1500 meters. Although these northern and southem layers are found at similar depths, the southern layer has a greater $\sigma_{2}$ density of 37.13 at the salinity maximum than the $\sigma_{2}$ densities of 36.95 and 37.10 
TABLE - 2 Summary of the physical and chemical characteristics of various water masses observed during the Moteor 11/5 expedition in the South Atlantic and northern Weddell Sea areas, The values represent extreme values observed during the expedition, but do not necessarily indicate the values for the "pure" end members of water mass. WSDW $=$ Weddell Sea Deep Water; WSBW $\Rightarrow$ Weddell Sea Bottom Water; $A A B W=$ Antarctic Bottom Water; AAIW $=$ Antarctic Intermediate Water, (+) and (-) signs indicate that the values listed comprise a local maximum and minimum respecitvely.

\begin{tabular}{|c|c|c|c|c|}
\hline Water Masses & 'BDWW & WSBW & $A A B W$ & AAIW \\
\hline Sections observed & N. Weddell & N. Weddol 1 & $58 \circ 5$ & Cape-Wedde 11 \\
\hline stations & $126-131$ & $130-131$ & $132-149$ & $149-164$ \\
\hline Depths (meters) & $500-800$ & $>4000$ & $3000-4000$ & $300-900$ \\
\hline Pot. Temp, (oC) & $0.2-0.5(+)$ & $<-0.75$ & $-0.25--0.50$ & $2.5-3.0$ \\
\hline Salintty $(0 / 00)$ & $34.67-34.68(t)$ & $34.64-34.69$ & $34.65-34.68$ & $34.0-34.3$ \\
\hline Dentsty $\left(\sigma_{0}\right)$ & $27.82-27.84$ & $>27.85$ & 27.85 & $27.20-27.60$ \\
\hline Density $\left(\sigma_{2}\right)$ & $37.10-37.13$ & $>37.225$ & $37.17-37.20$ & $36.4-36.6$ \\
\hline $\mathrm{TCO}_{2} \quad(\mathrm{uM} / \mathrm{kg})$ & $2260-2270(+)$ & $<2245$ & $2250-2255$ & $21.50-22,00$ \\
\hline $\mathrm{pCO}_{2}$ \& $20^{\circ} \mathrm{C}$ (uatm) & $1160-1120(+)$ & $<1040$ & $1075-1100$ & $800-1000$ \\
\hline $\mathrm{O}_{2} \quad(\mathrm{uM} / \mathrm{kg})$ & $200-210(-)$ & $>260$ & $2.30-2.40$ & $210-250$ \\
\hline AOU (UM/kg) & $140-150(+)$ & $<100$ & $110-120$ & $50-100$ \\
\hline $\mathrm{NO}_{3} \quad(\mathrm{uM} / \mathrm{kg})$ & $33 \cdot 5-34.5(+)$ & $<32,0$ & 33 & $28-34$ \\
\hline $\mathrm{PO}_{4} \quad(\mathrm{uM} / \mathrm{kg})$ & $2.35-2.39(+)$ & $<2.25$ & 2.35 & $1.9-2.3$ \\
\hline $\mathrm{StO}_{1} \quad(\mathrm{uM} / \mathrm{kg})$ & $125-132(+)$ & $<110$ & $125-130$ & $20-50$ \\
\hline TAL.K (UEg/kg) * & $2350-2360$ & 2355 & 2360 & $2290-2310$ \\
\hline POL.ALK (UEq/kg)** & $2410-2.415$ & $2410-2418$ & $2415-2418$ & $2375-2.390$ \\
\hline
\end{tabular}

*/ T'otal alkalinity ('IALK) values computed using the total $\mathrm{CO}_{2}$ concentration and $\mathrm{PCO}_{2}$ a $20^{\circ} \mathrm{C}$ data at observed salinities.

* / Potential a]kalinity (Pot.AI.K) computed as [(TALK) " (NO,')] and normalized to a salinity of $35.000 / 00$. 


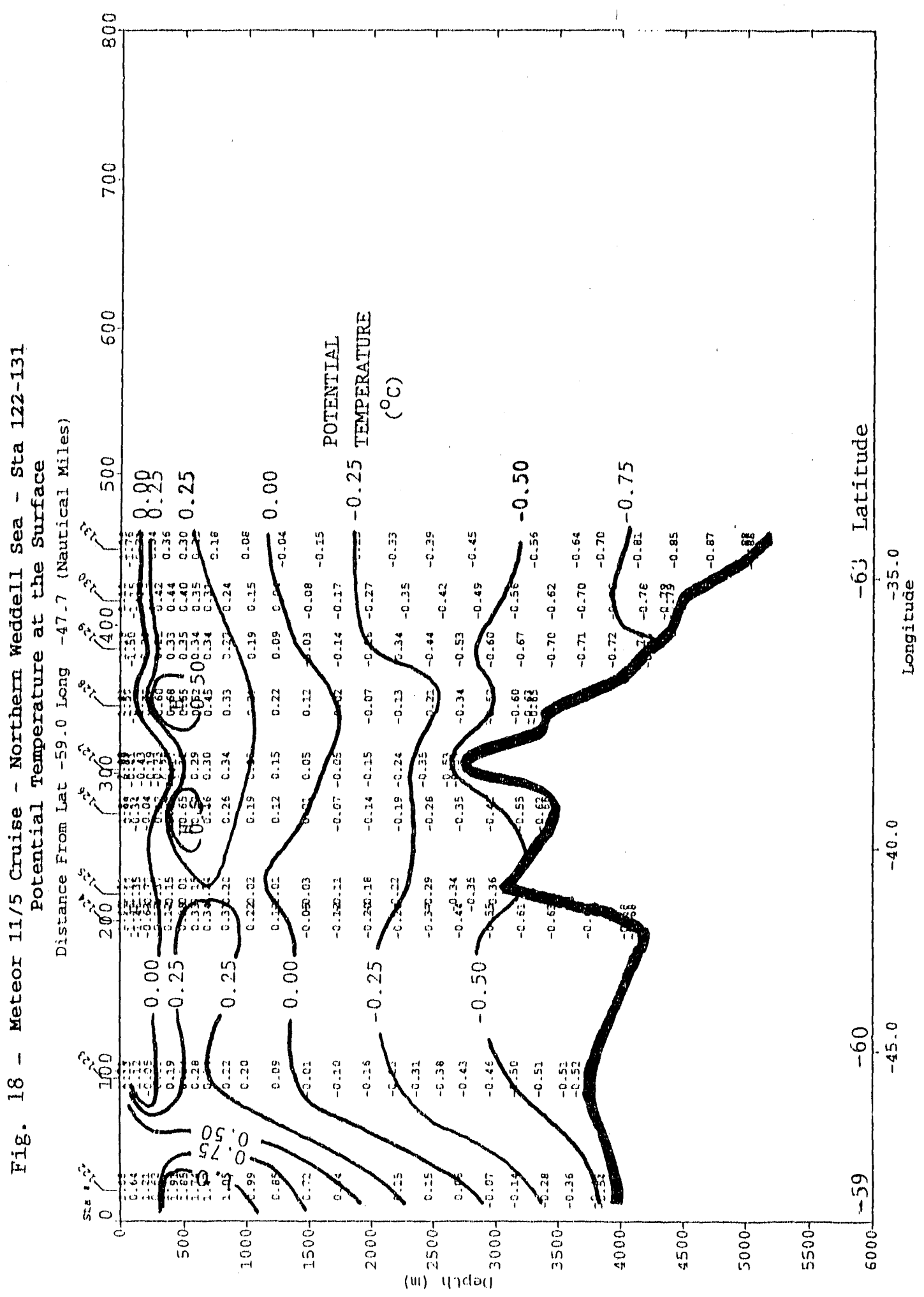




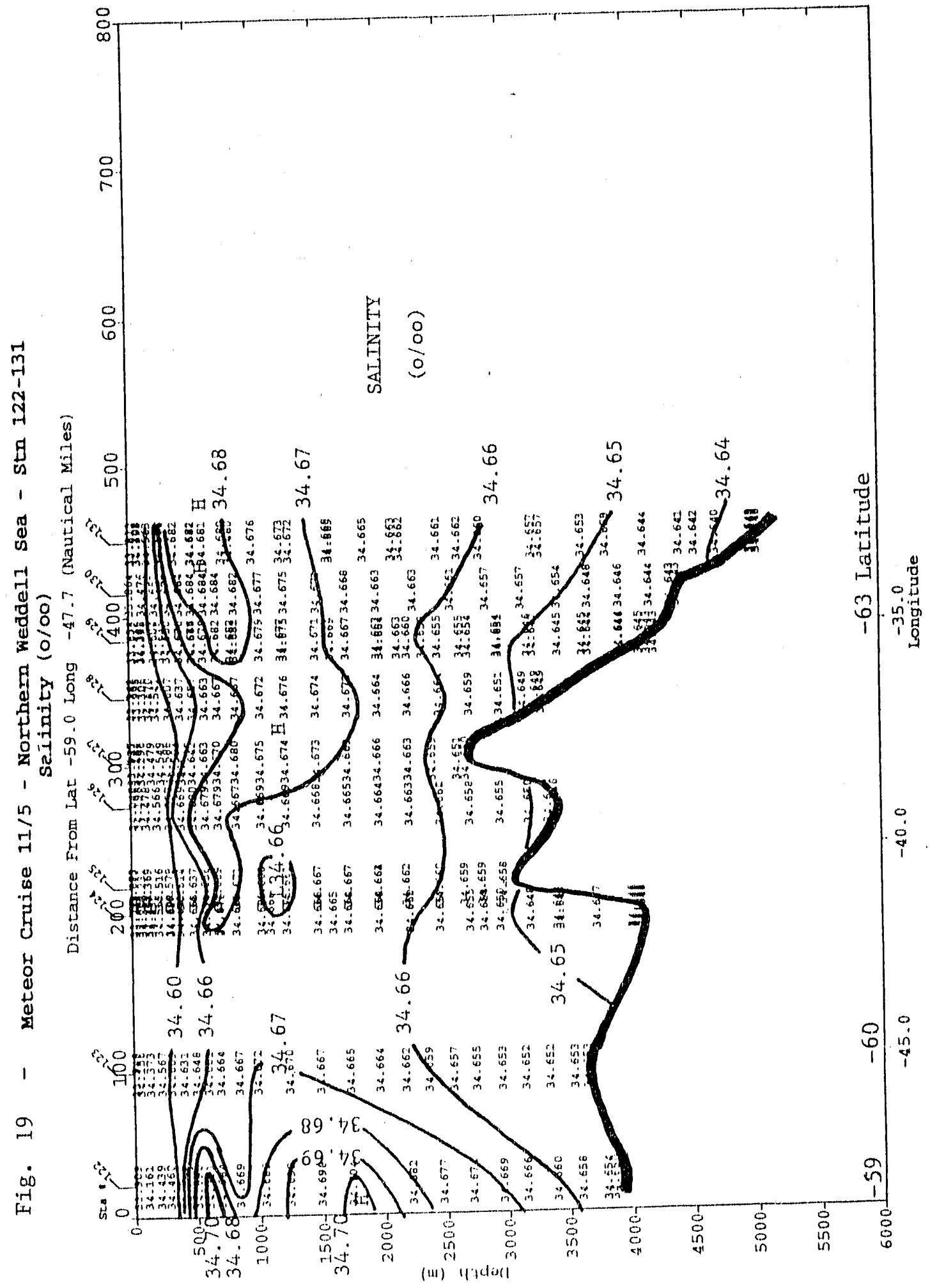


Fig. 20 - Potential temperature-salinity relationships observed in the northern Wedde11 Sea section. WSDW = Weddell Sea Deep Water; $W S B W=$ Wedde11 Sea Bottom Water.

F/S Meteor Cruise 11/5

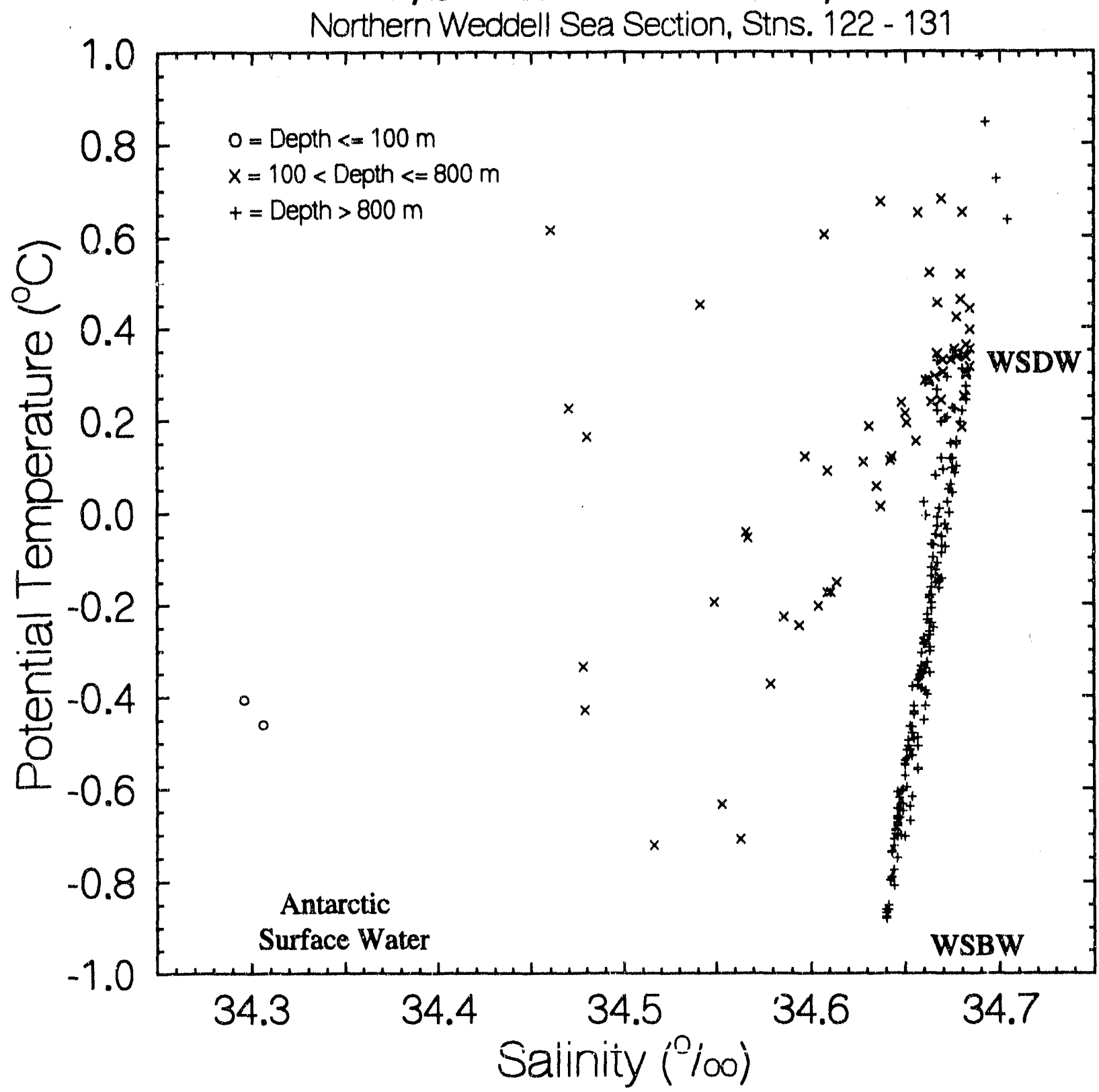



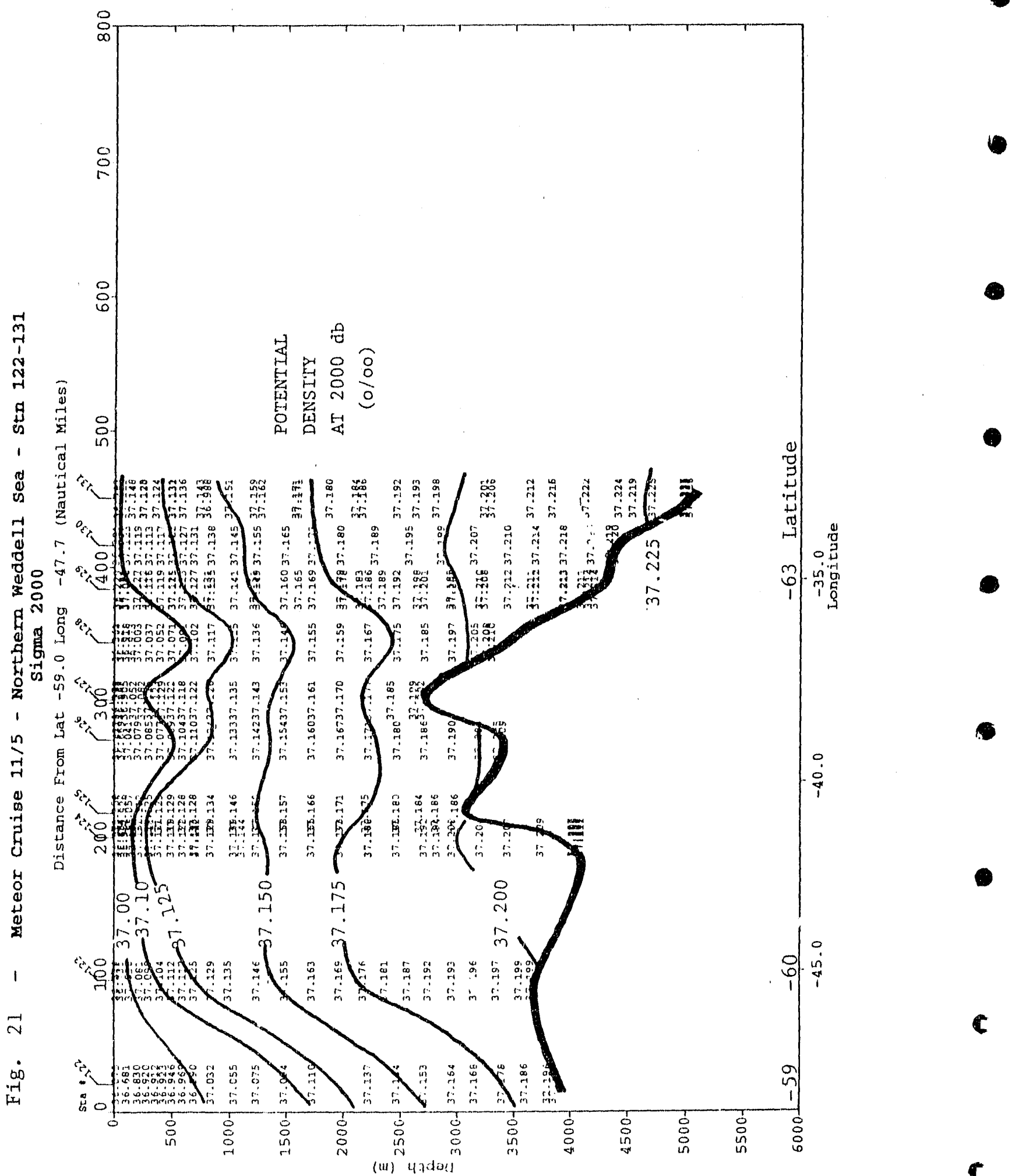


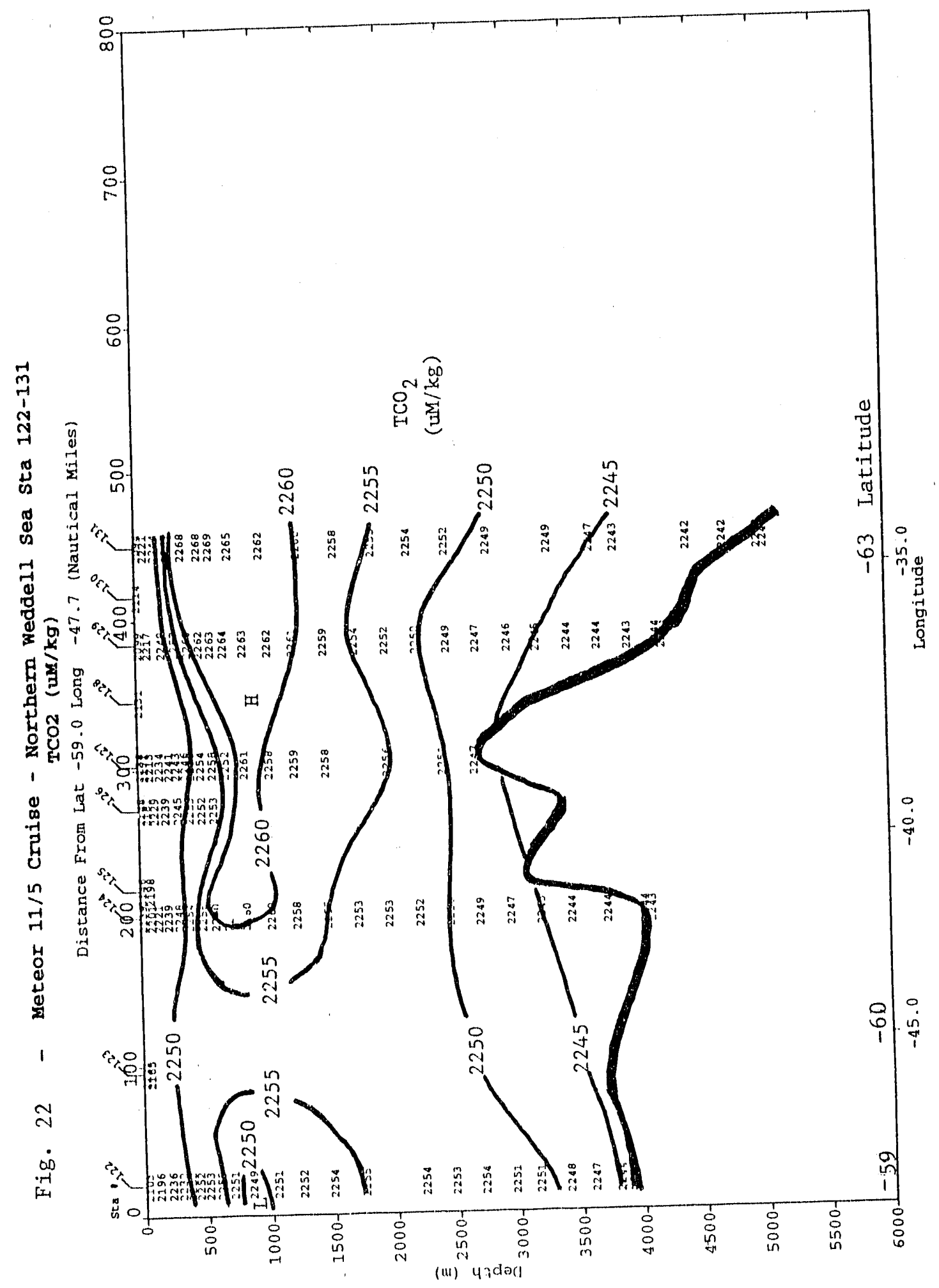


at the respective salinity maximum for the northern layers. Furthermore, the distributions of $\mathrm{pCO}_{2}$

(Fig. 23), phosphate (Fig. 27) and silica (Fig. 28) appear to indicate that the southern features have separate origins from the warmer layer to the north. The southern layer appears to represent the Weddell Deep Water, which circulates at intermediate depths within the Weddell gyre and is derived from the Circumpolar Deep Water (Jacobs et al., 1985). Since it receives fresh water and is cooled during its circuit around the Weddell Sea, it has lower salinity and temperature but higher $\mathrm{pCO}_{2}$ and greater concentrations of total $\mathrm{CO}_{2}$, silica and phosphate than its parent Circumpolar Deep Water. The characteristic chemical properties for these water masses are summarized in Table 2. 


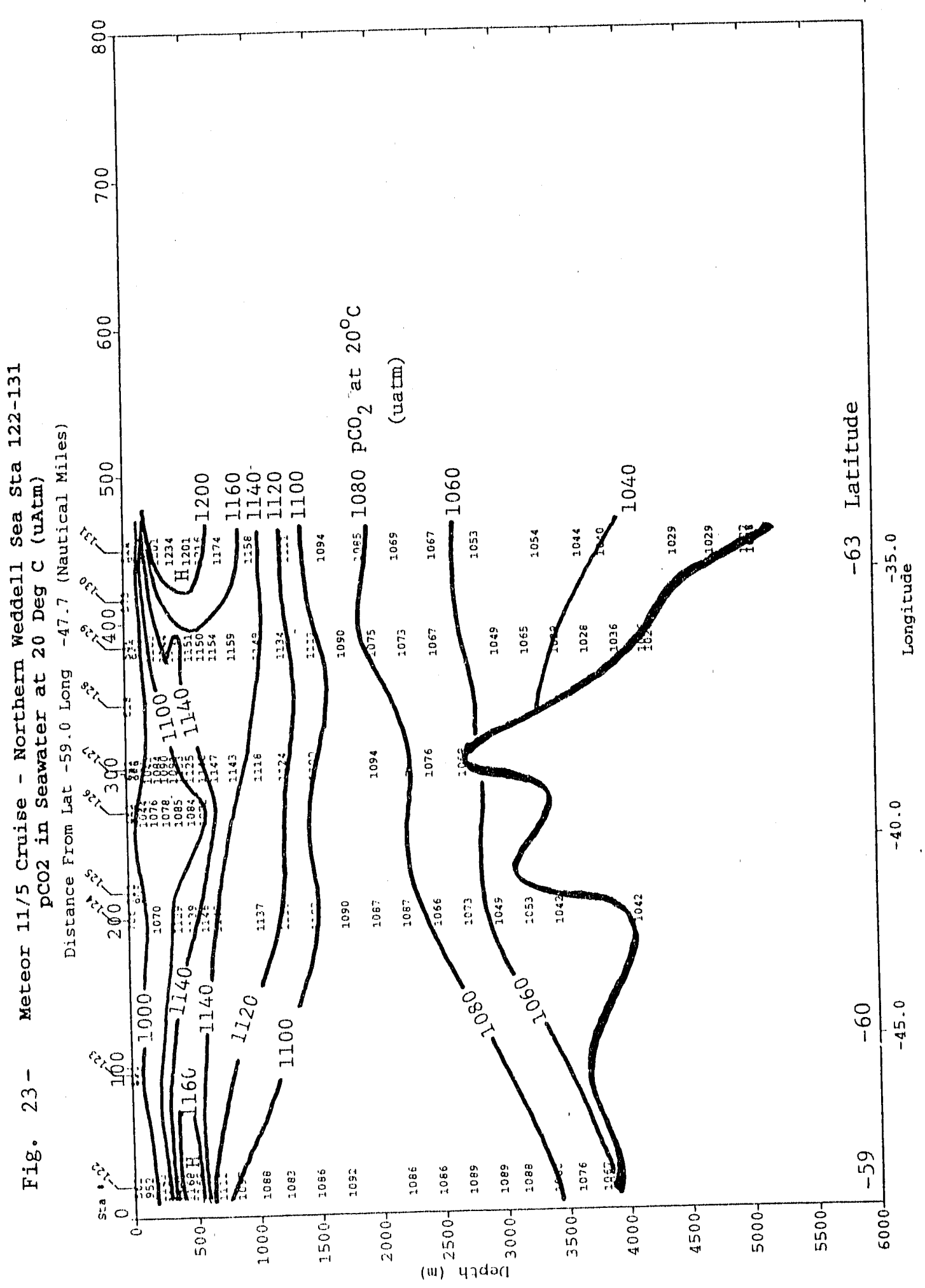




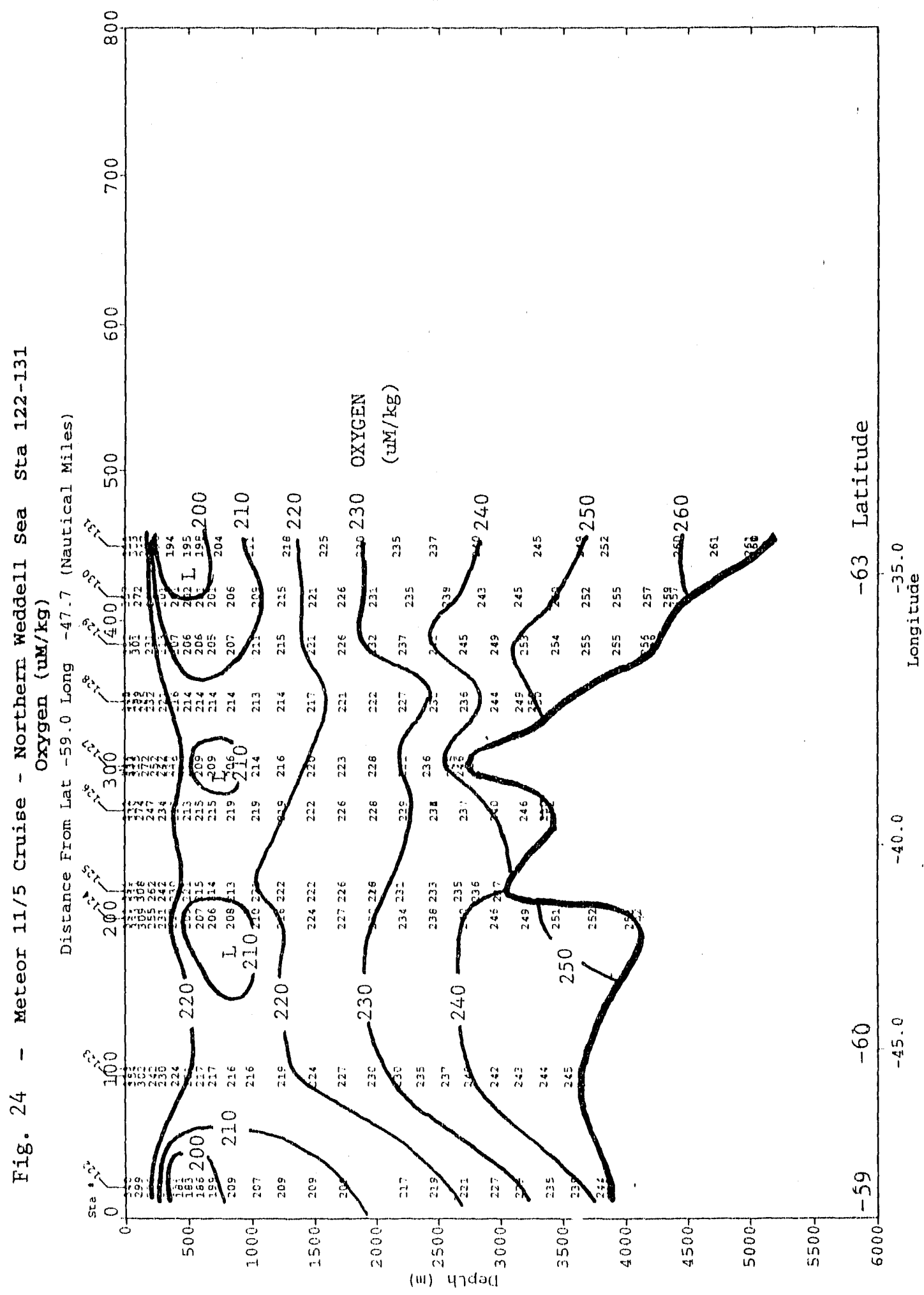




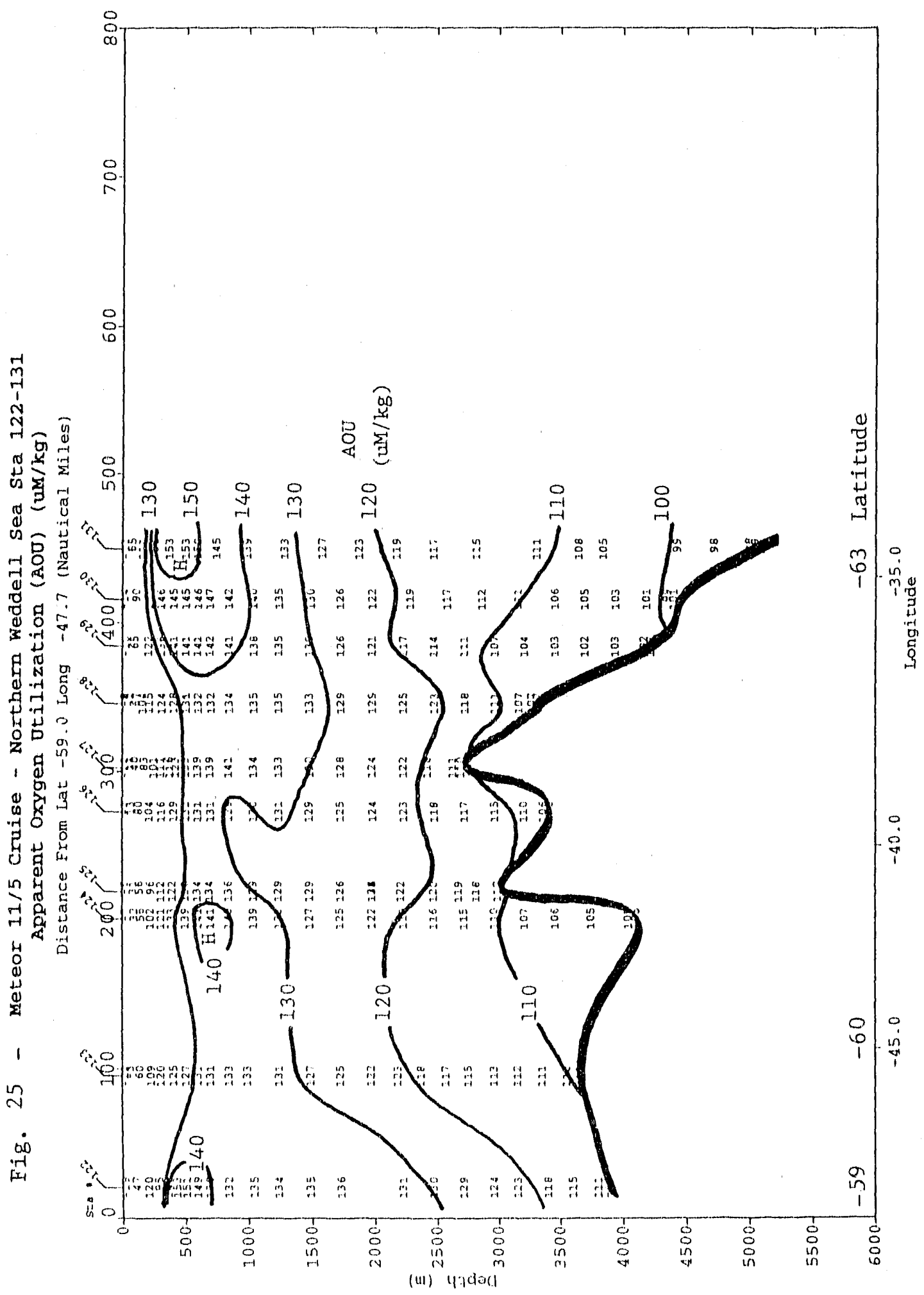




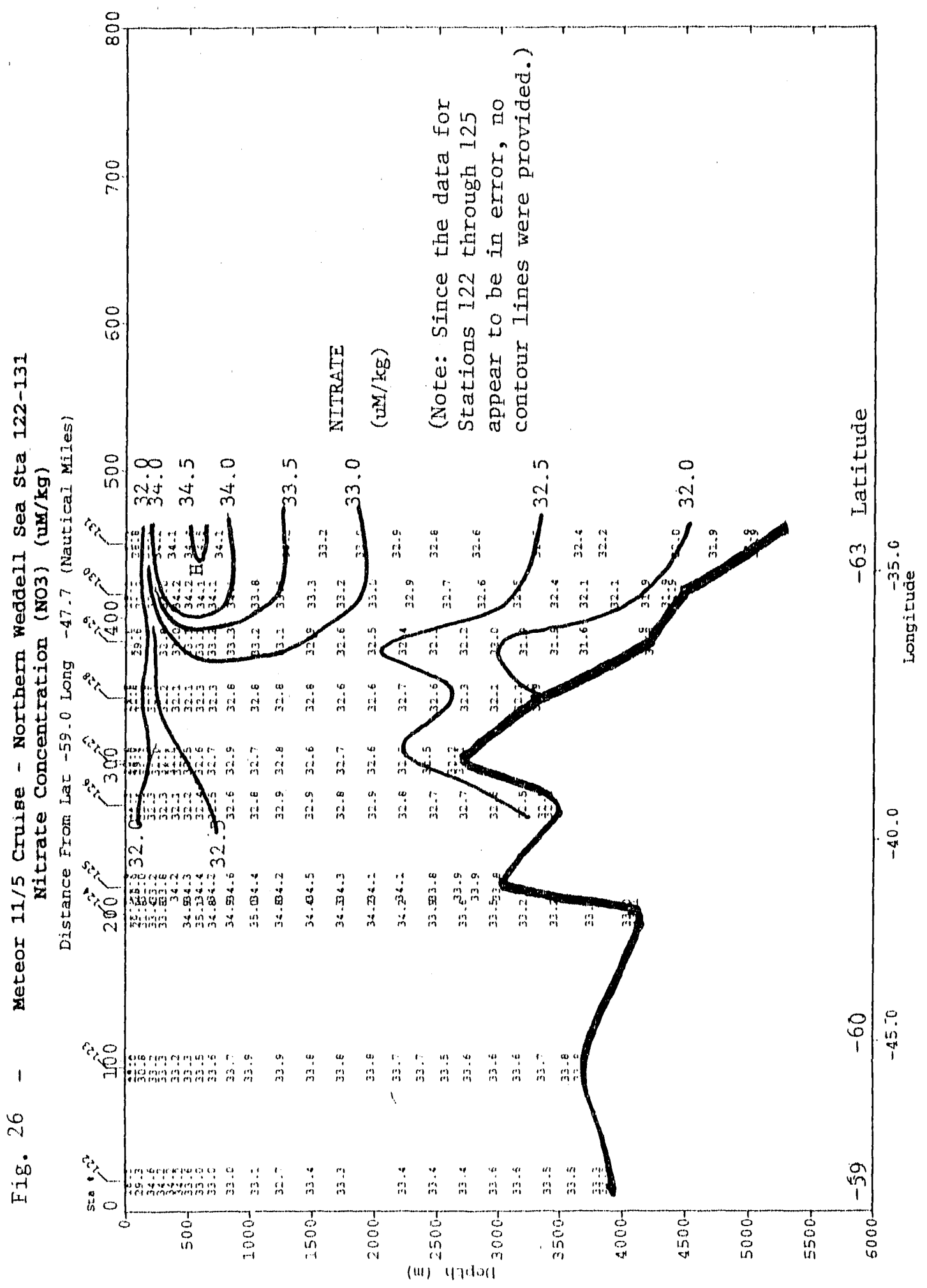




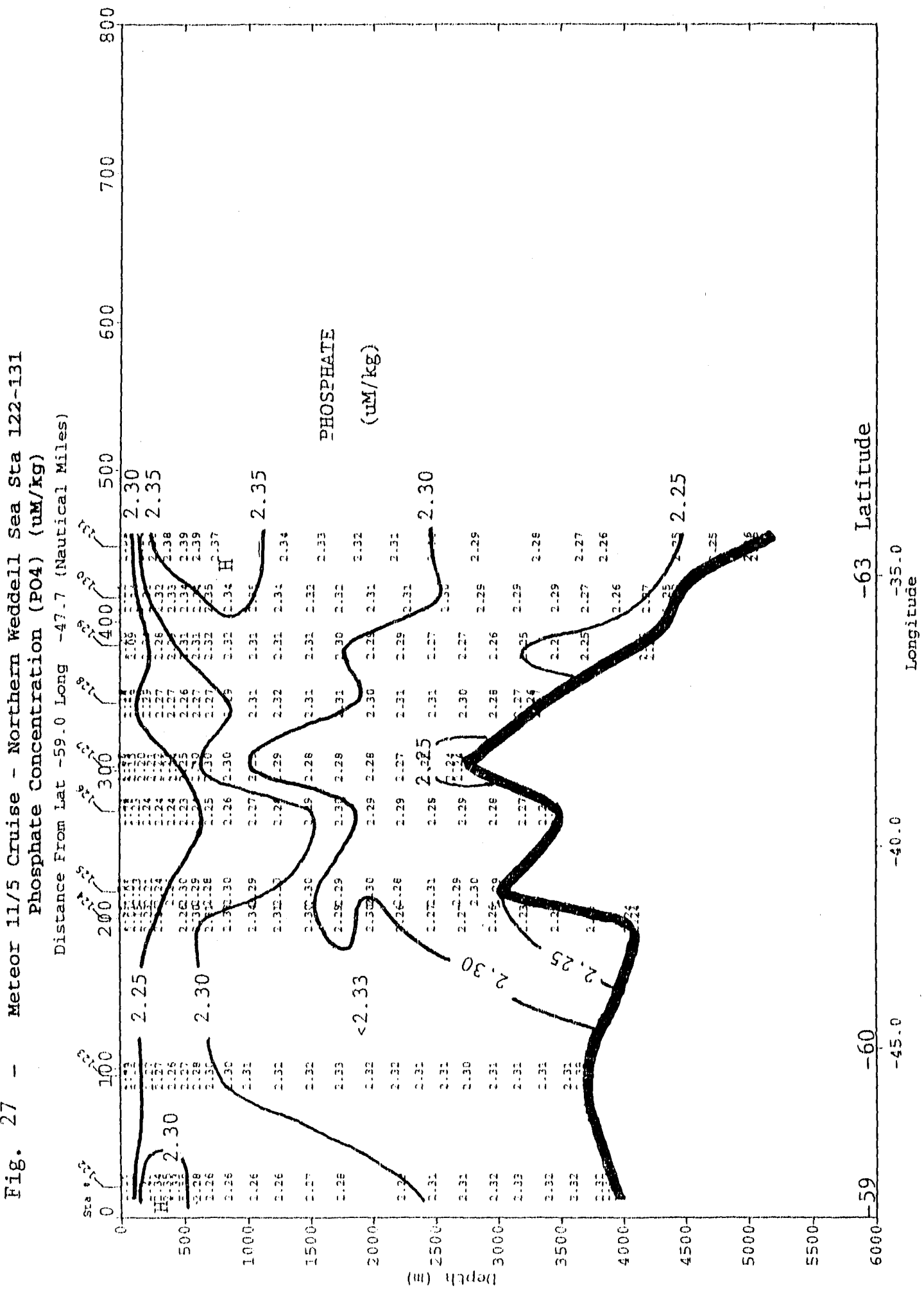




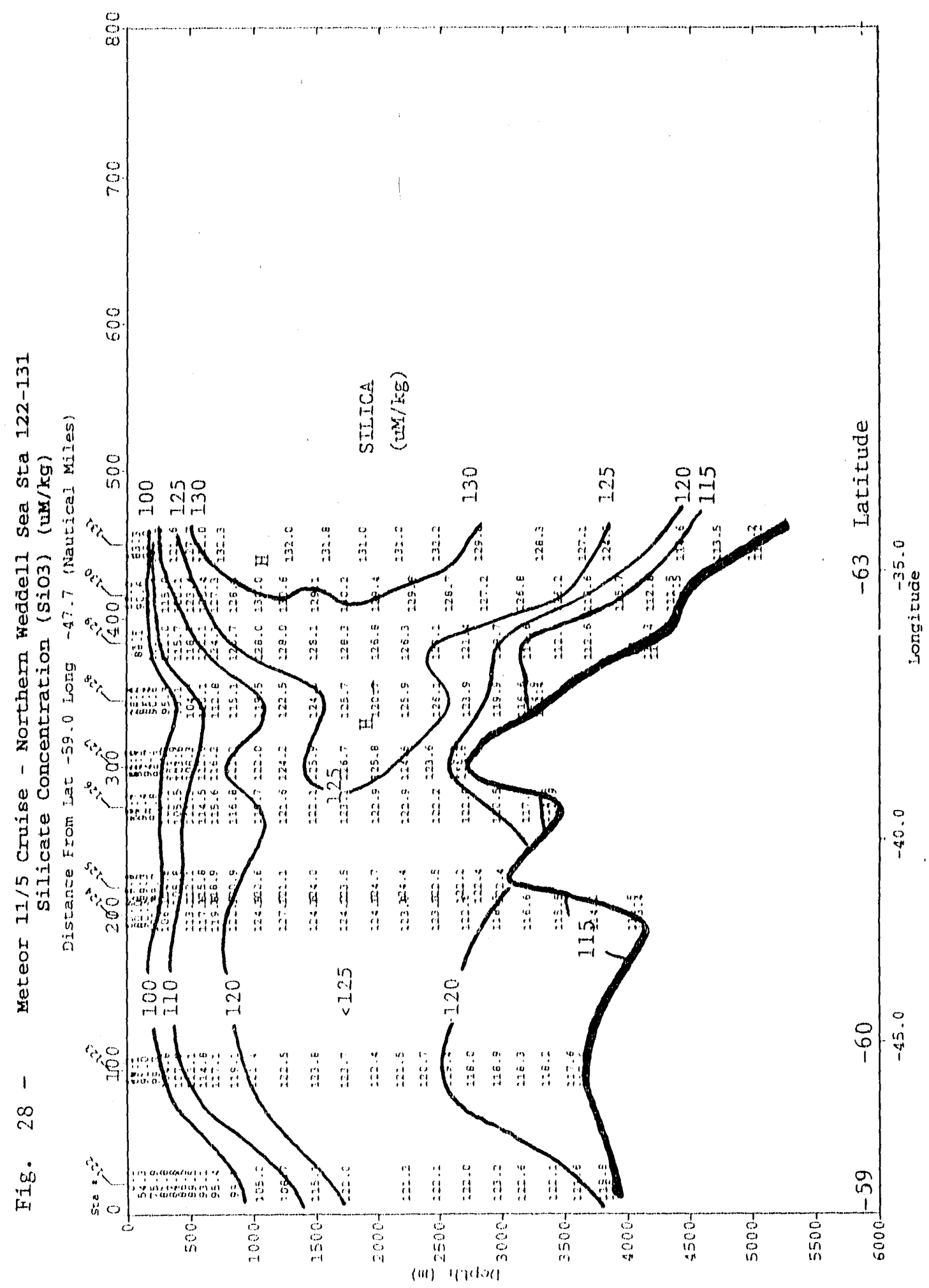

$\epsilon$

E 
III-4) The 58"S Section (Stations 132-149):

This section represents a E-W zonal section along approximately $58^{\circ} \mathrm{S}$ between the longitudes of about $25^{\circ} \mathrm{W}$ and the prime meridian. The temperature and salinity values indicate that this section is dominated by the Circumpolar Leep Water in the upper 1500 meters and the deep and bottom waters from the Weddell Sea below about 1500 meters. The potential temperature-salinity relationships observed in this section are shown in Fig. 31. Wavy patterns of the contour lines are found all the depths in every property including temperature (Fig. 29), salinity (Fig. 30), density (Fig. 32), oxygen (Figs. 35 and 36) and silica (Fig, 39). In a depth range from about 300 and 1000 meters (i.e. Circumpolar Deep Water), strong lateral variations are observed. Warmer waters outlined by the 1.0 and $1.5^{\circ} \mathrm{C}$ isotherms (Fig. 29) not only have higher salinity values which are outlined by the 34.69 and $34.70 \mathrm{o} / 00$ contours (Fig. 30), but also contain lower oxygen (see the $200 \mathrm{uM} / \mathrm{kg}$ contour for oxygen in Fig. 35 and the $140 \mathrm{uM} / \mathrm{kg}$ contour for AOU in Fig. 36). These features indicate dynamtcally active flow of water across this section.

It is noted that the coherent wavy patterns are not observed in the contour lines for the $\mathrm{pCO}_{2}$ and the concentrations of total $\mathrm{CO}_{2}$, nitrate and phosphate. In the sections for total $\mathrm{CO}_{2}$ and $\mathrm{pCO}_{2}$ (Figs. 33 and 34), it is seen that the measurements were made in deep waters at every other station or only at the even numbered stations. This is because the measurements could not be made fast enough to accommodate the samples taken at every station. Since the wavy patterns observed in the eastern (or right) half of the section, the temperature, salinity, density and oxygen values (see Figs. 29, 30, 32 and 35) tend to exhibit a wave length of two station-distances (or about $2^{\circ}$ in longitude), the $\mathrm{CO}_{2}$ data were obtained only near the bottom of waves but not near the top of waves. Accordingly, the lateral distributions observed for total $\mathrm{CO}_{2}$ and $\mathrm{pCO}_{2}$ have been inadvertently smoothed due mainly to undersampling for lateral distances. For future expeditions in this area and other highly dynamic areas, closer station distances must be achieved.

The distributions of nitrate and phosphate shown in Figs. 37 and 38 are not consistent with those for oxygen and silica particularly in waters below about 1000 meters. This is due mainly to the small dynamic range for these two properties. Below 1000 meters, the nitrate and phosphate concentrations vary between 33.5 and $34.0 \mathrm{uM} / \mathrm{kg}$ for the former and between 2.30 and $2.35 \mathrm{uM} / \mathrm{kg}$ for the latter. The precisions of measurements attained for these quantities during this expedition were not refined enough to resolve the variations satisfactor ly. 

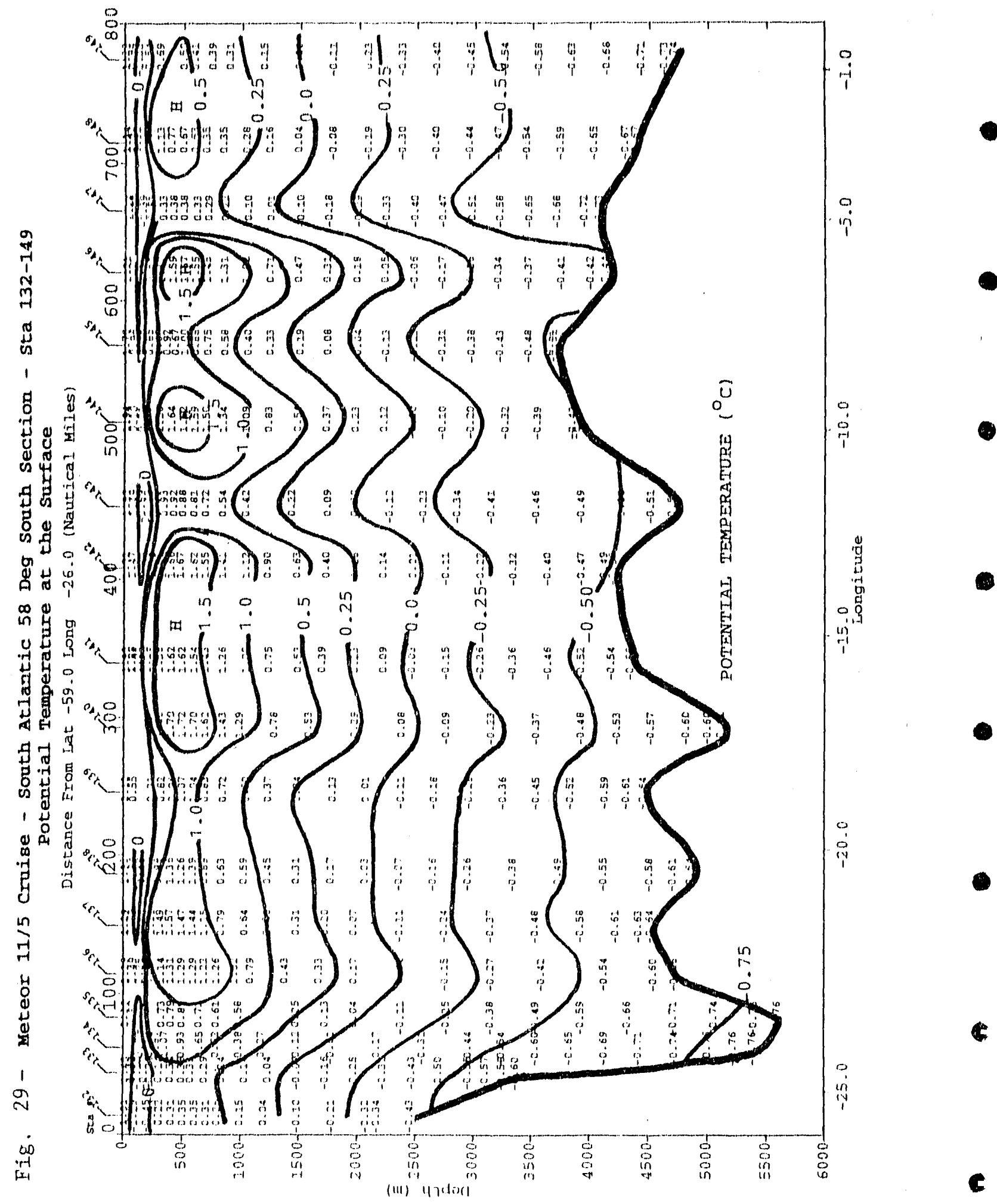


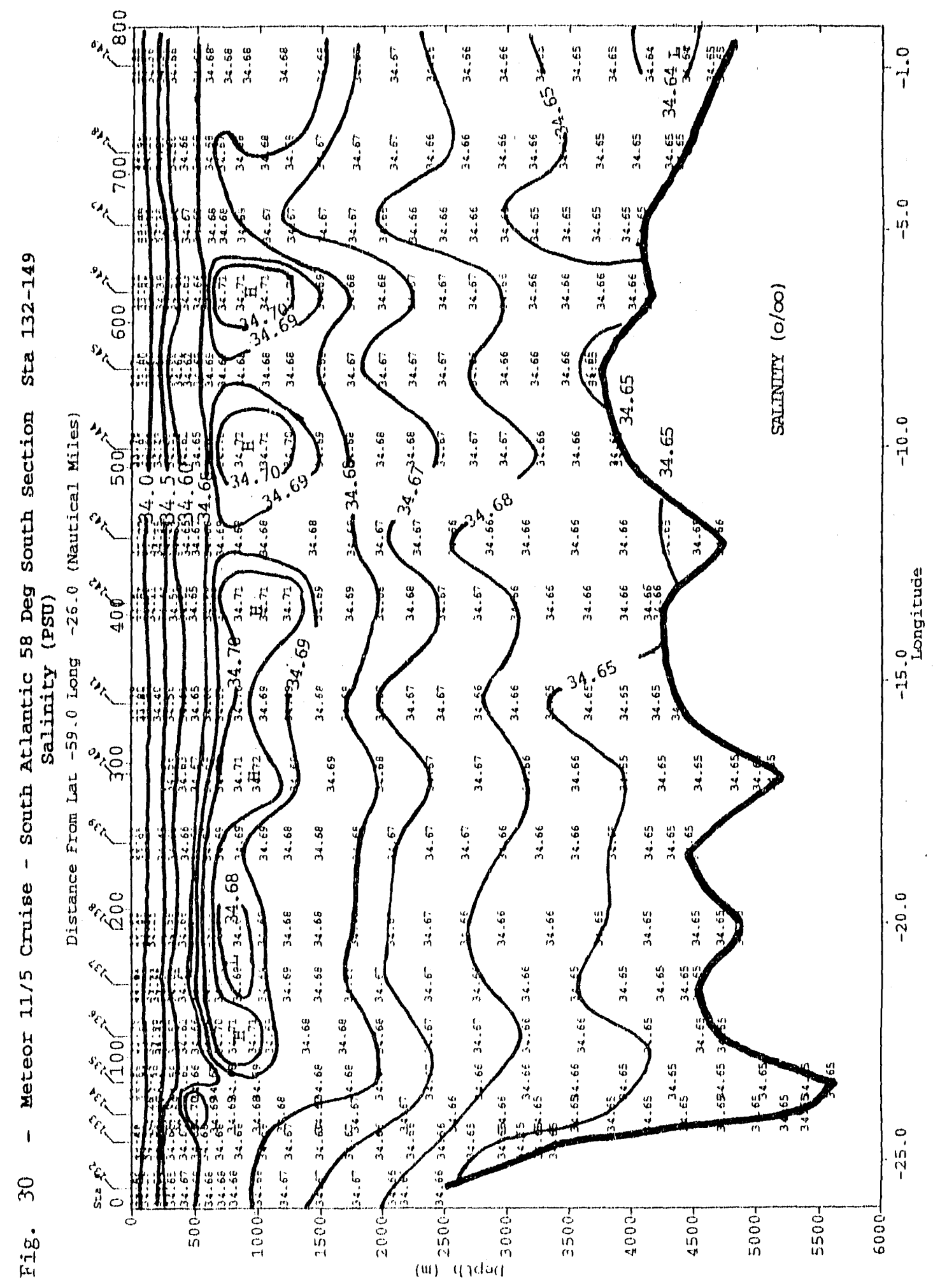


Fig. 31 - Potential temperaturemsalintty relationshlps observed In the $58^{\circ} \mathrm{S}$ section in the Southern Ocean. CPDW $=$ Cl.rompolar Deep Water; WSDE = Wedde1L Sea Deep Water; $\mathrm{AABW}=$ AntarctLc Bottom Water; WSBW = Wedcle11 Sea Bottom Water.

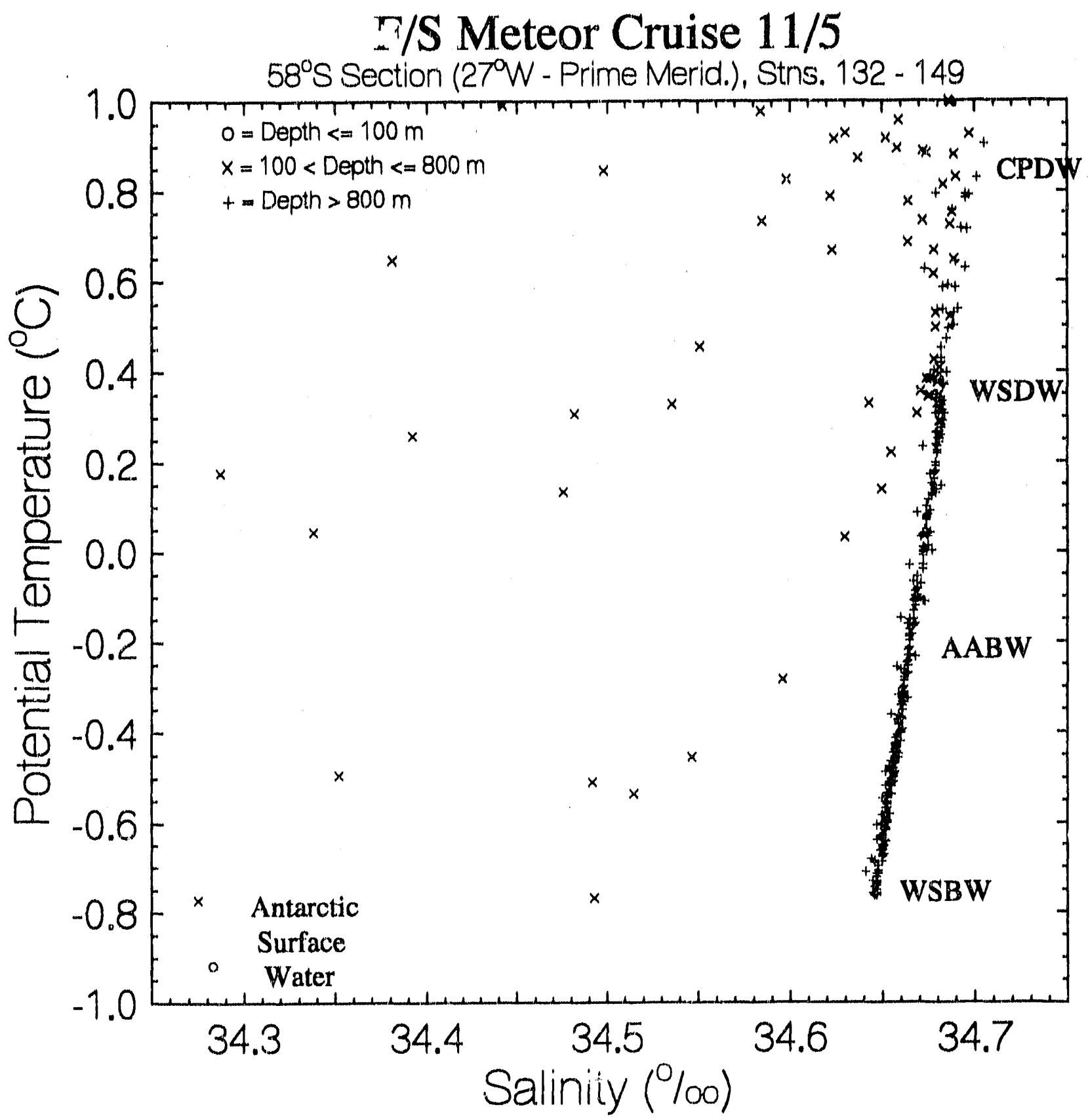




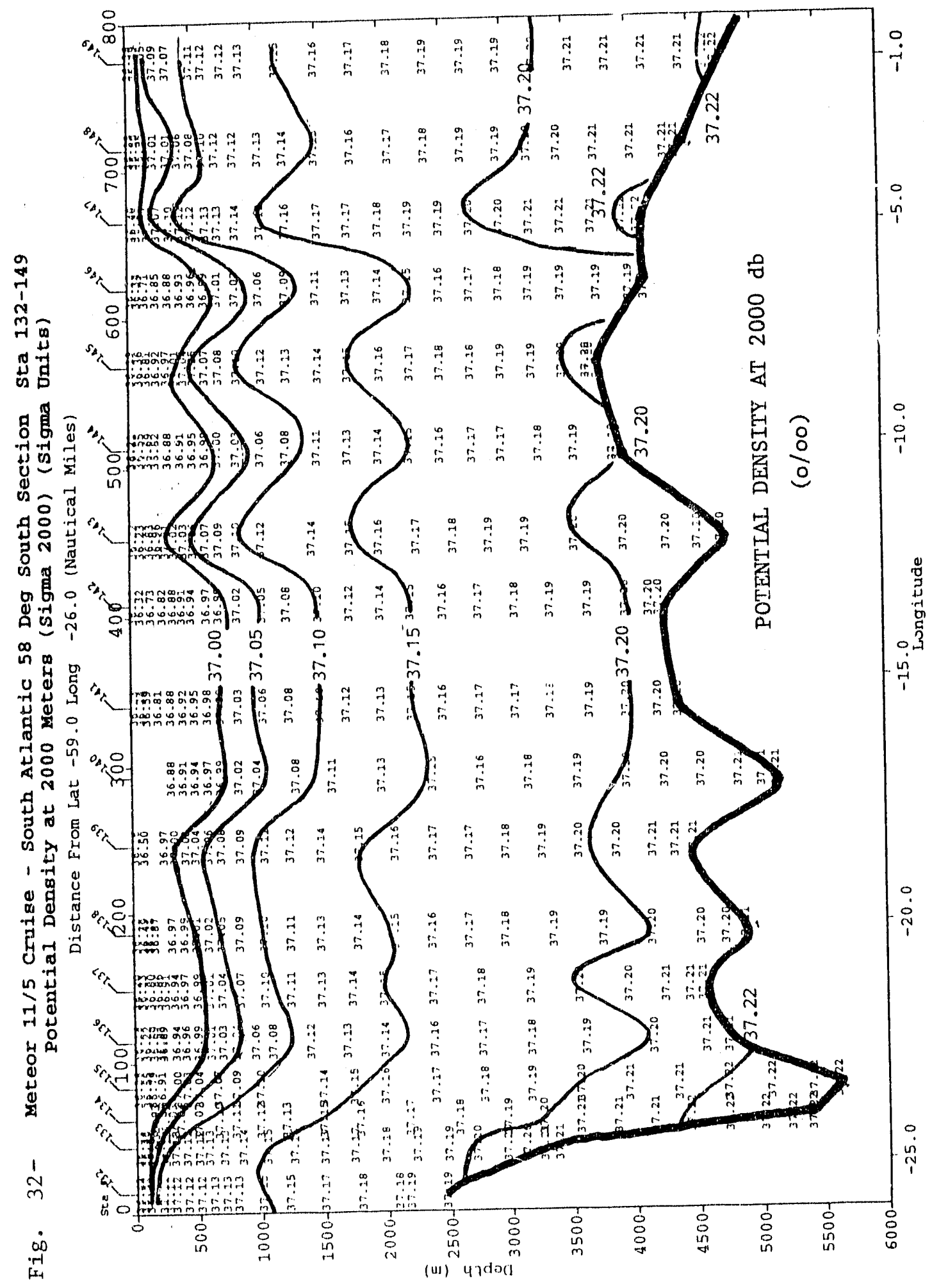



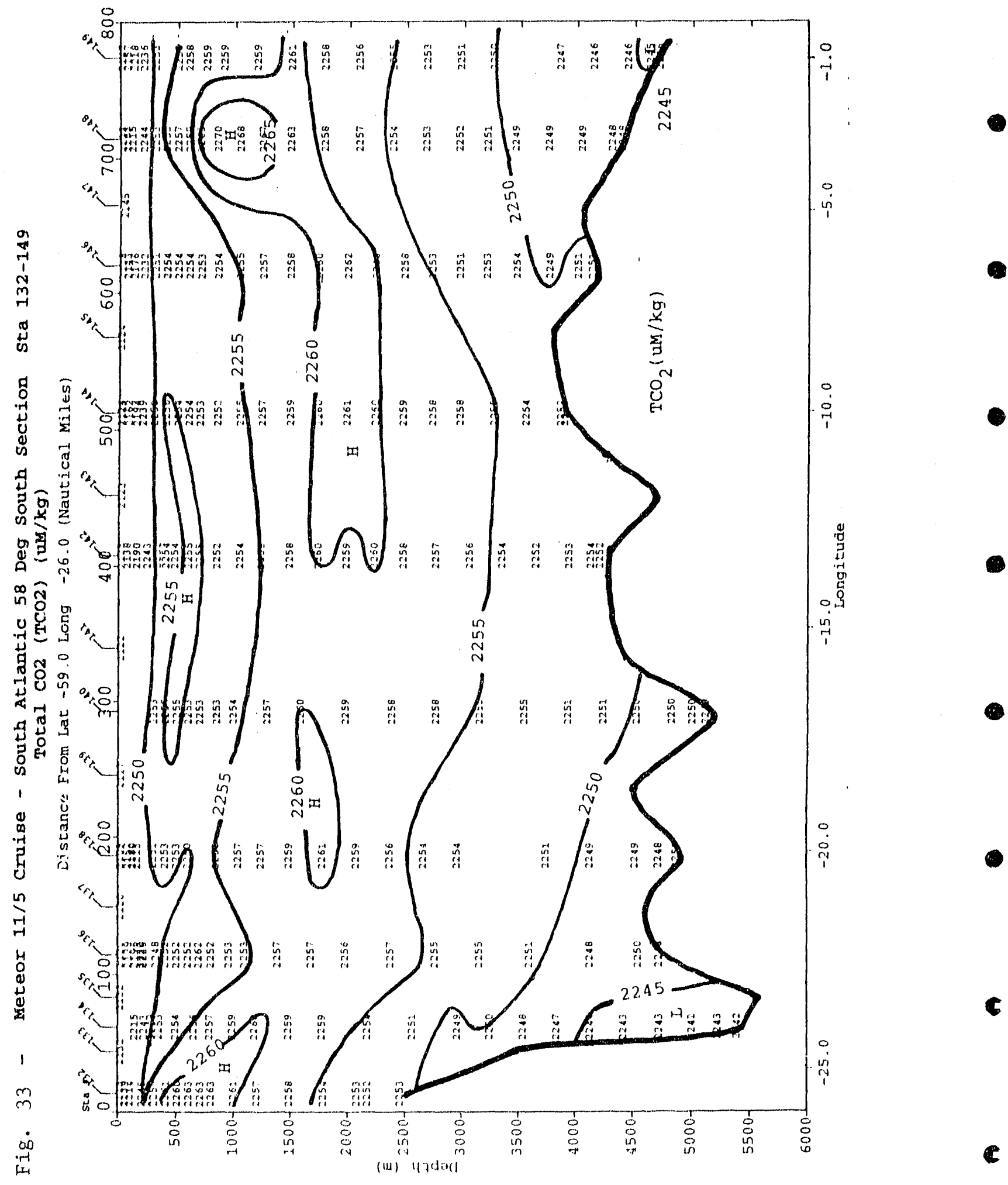


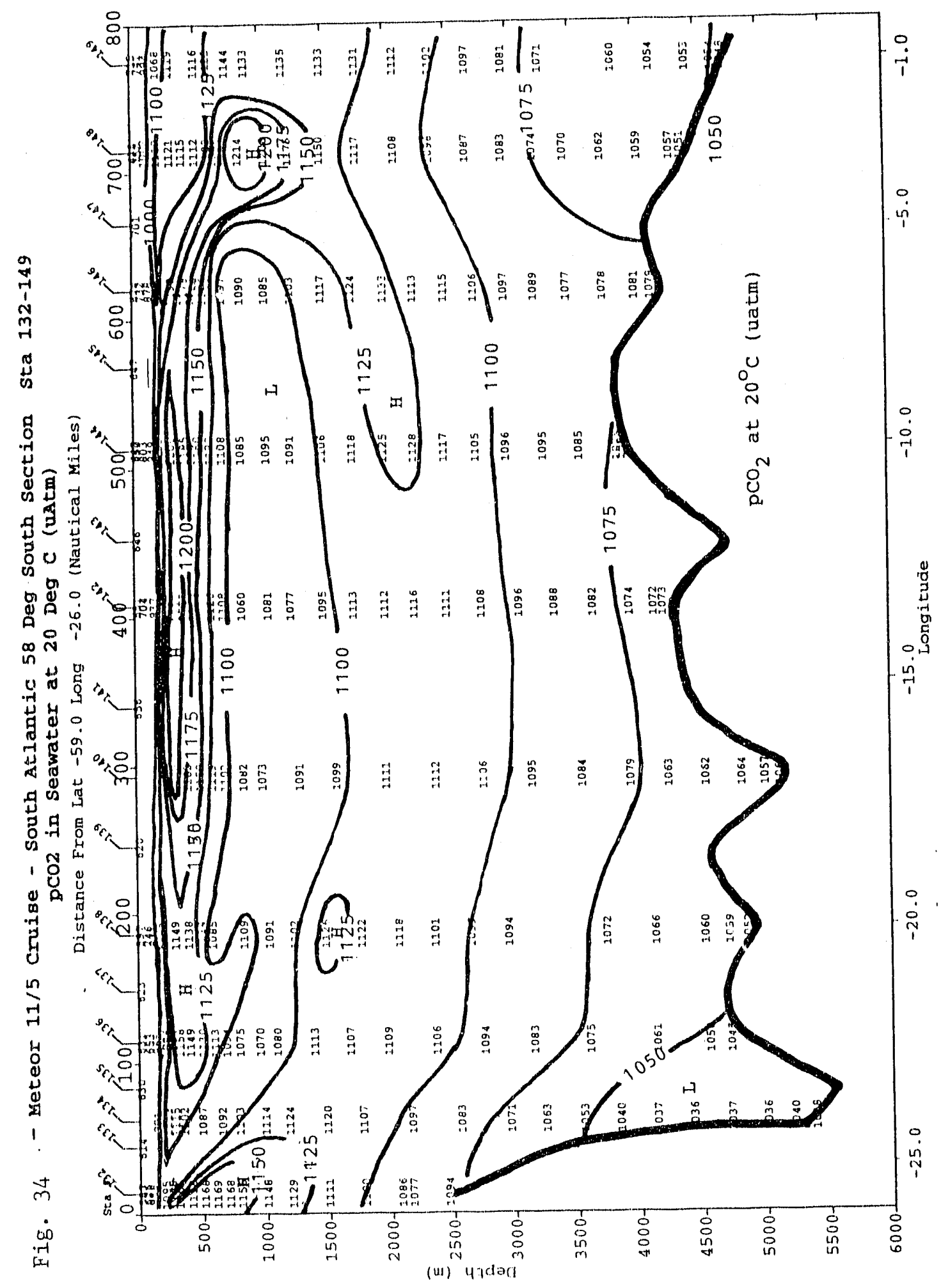




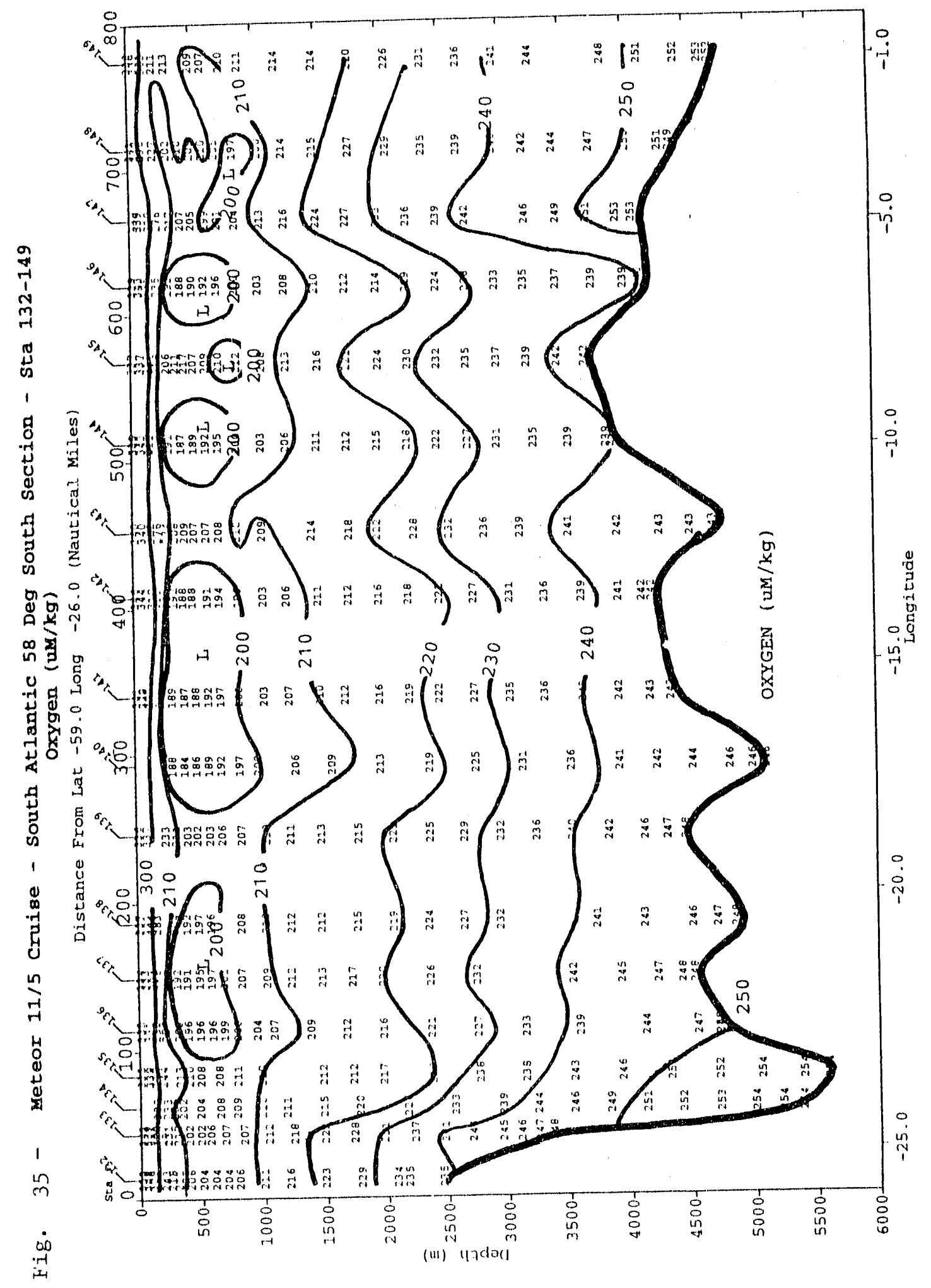




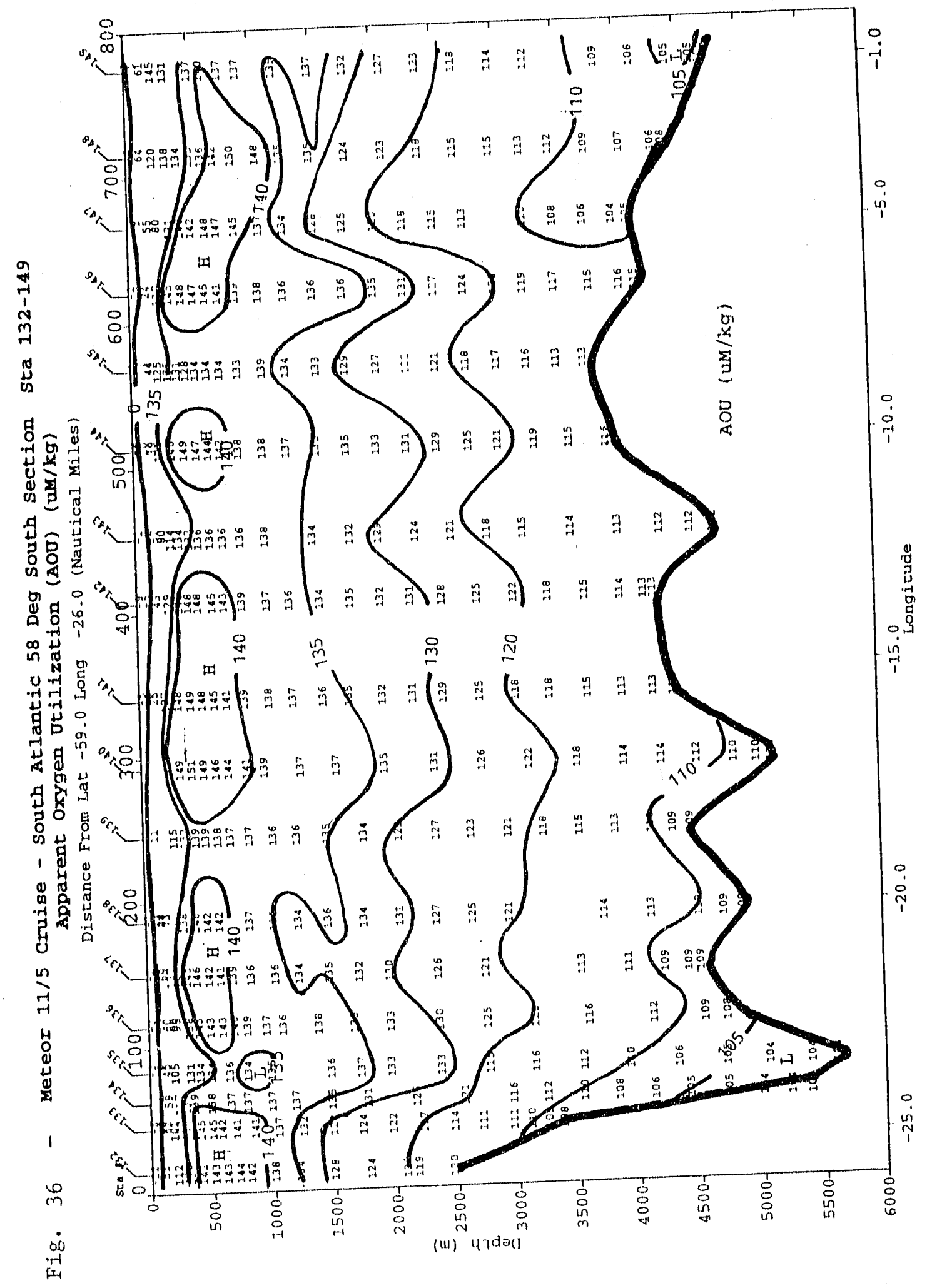




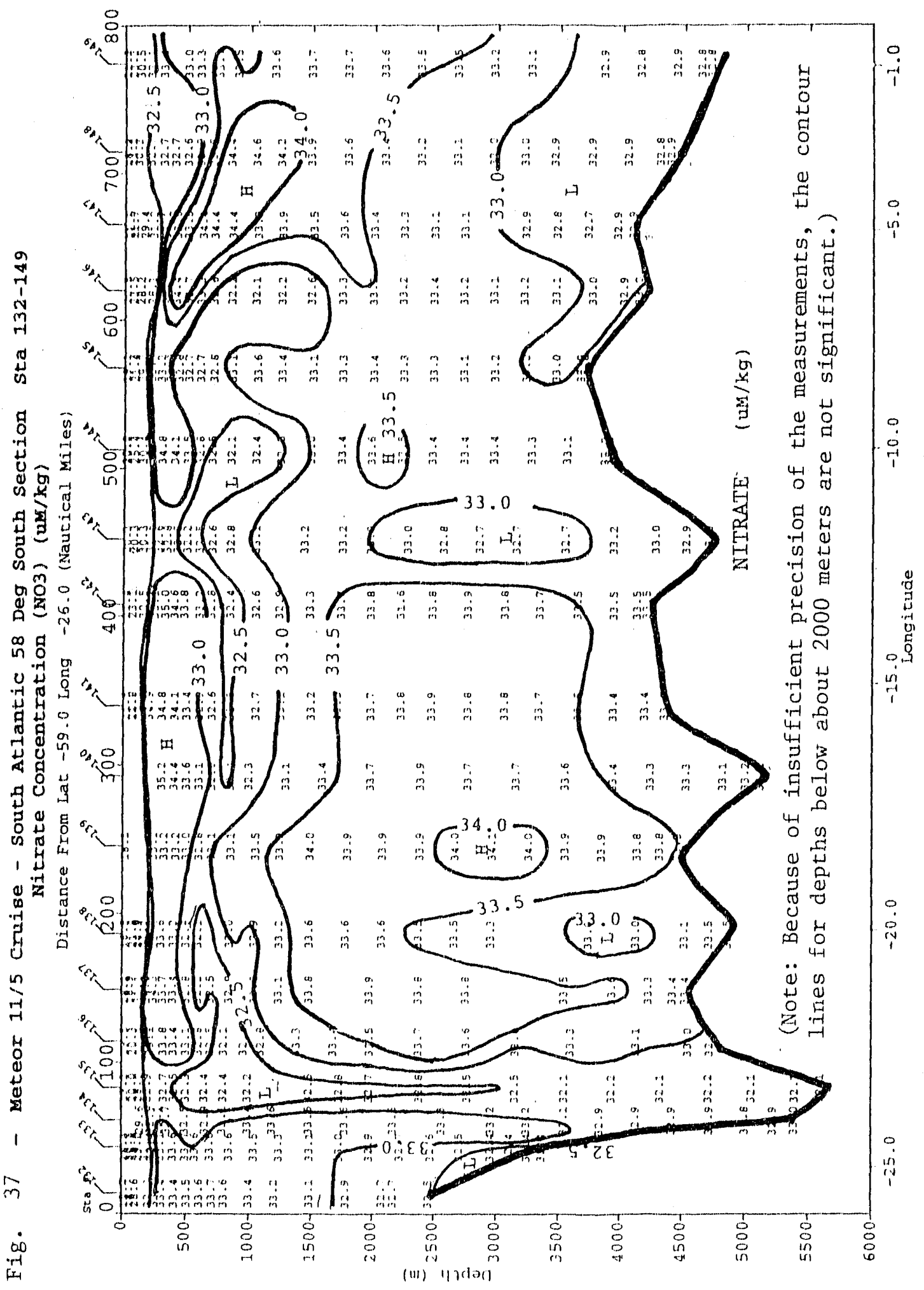




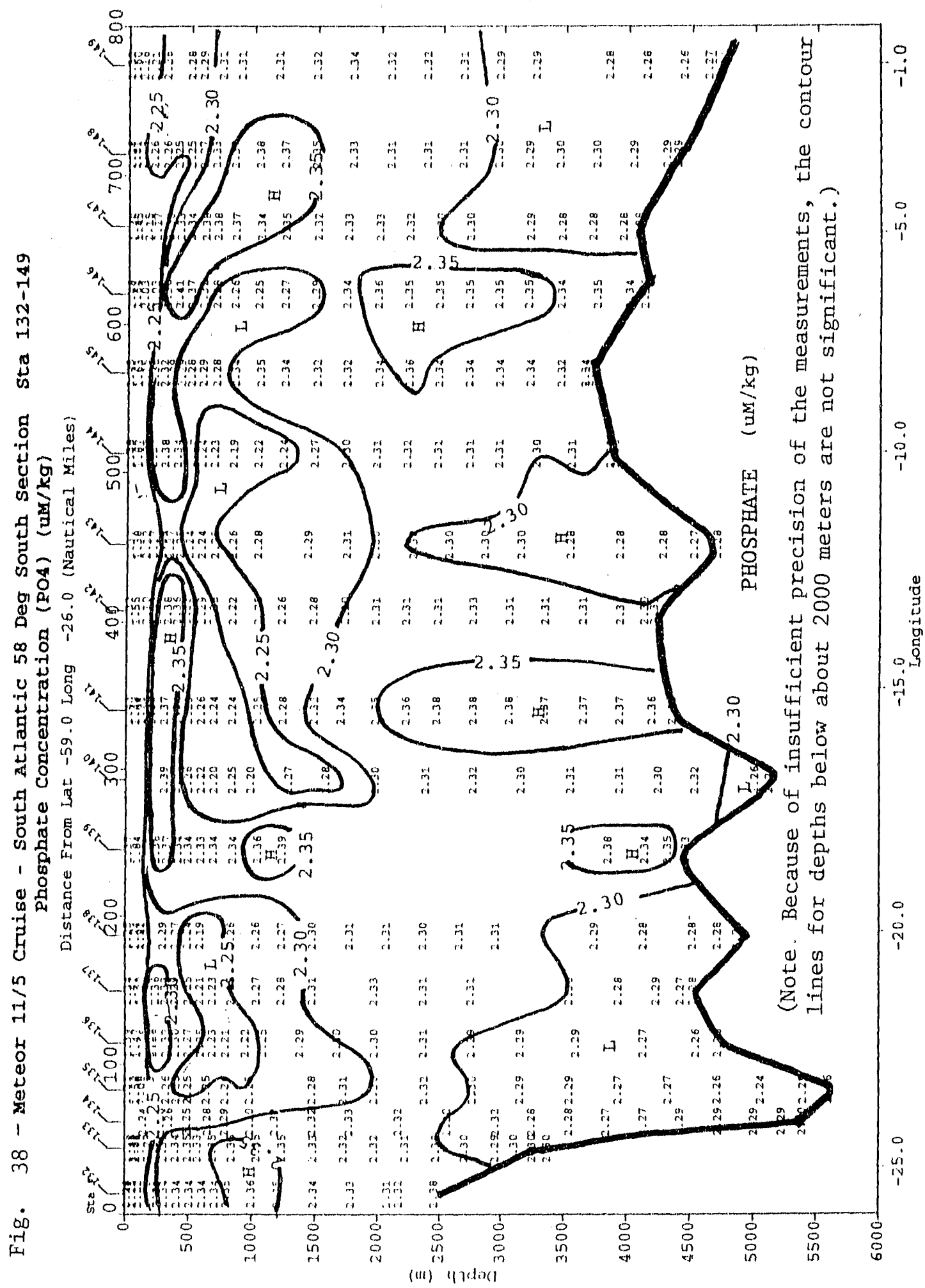




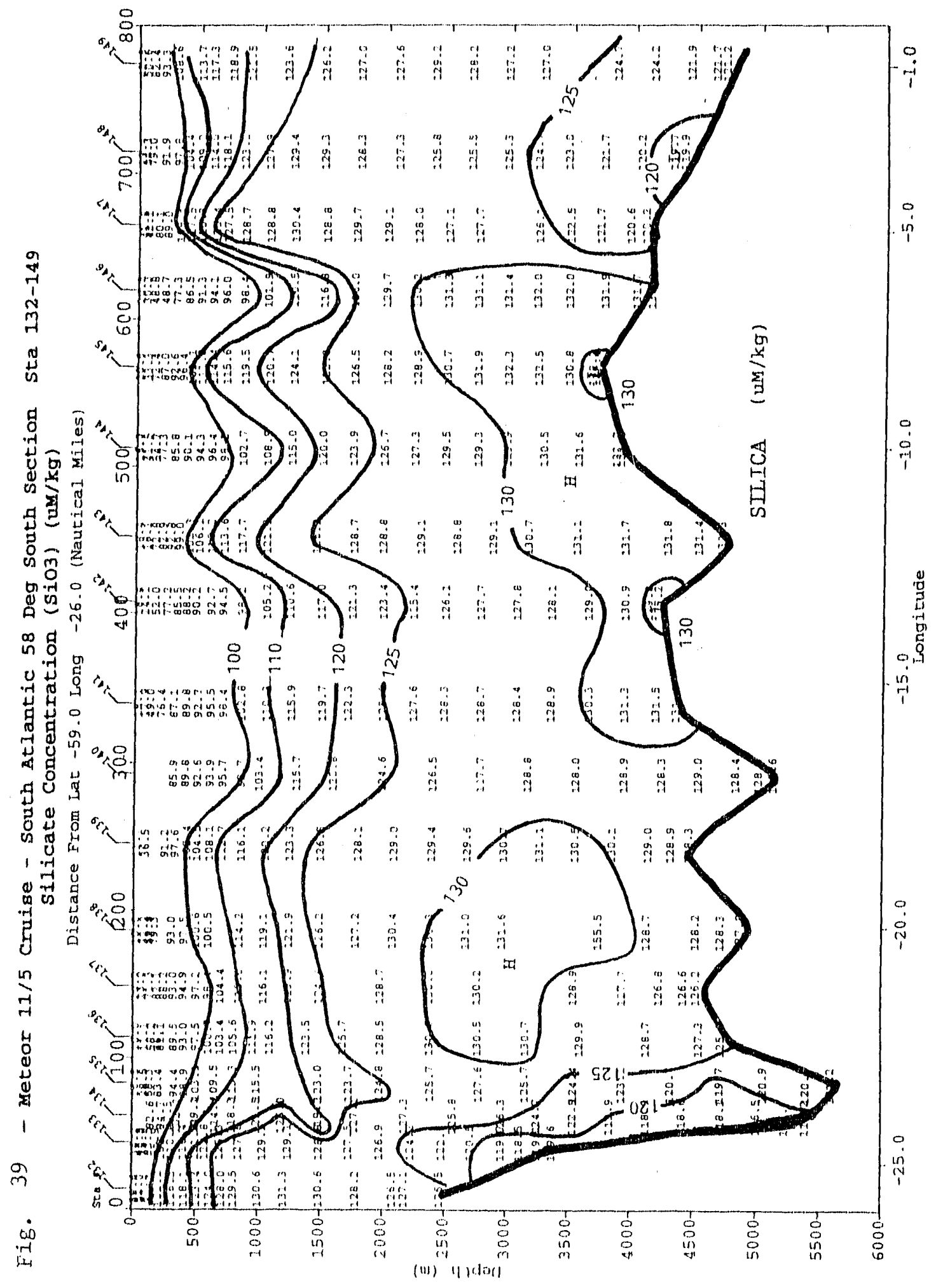

c 


$$
-61-
$$

In this section around 3000 meters deep, there is a layer of water with a typical temperature $(-0.25 \sim 0.50)$ and salinity $(34.65 \sim 34.67 \mathrm{o} / \mathrm{co})$ range for the Antarctic Bottom Water (AABW. This is commonly found in abyssal depths throughout the western basin of the South Atlantic Ocean. As seen in Fig. 31, the temperature and salinity values for the AABW fall between the warmer Weddell Sea Deep Water and the colder Weddell Sea Bottom Water. This suggests that the AABW consists roughly of a 1:1 mixture of the WSDW and WSBW. The characteristic chemical properties for the AABW are listed in Table 2. 
III-5) The Capetown-Weddell Section (Stutions 149-179):

This section represents a near-meridional section from the northeastern Weddell Sea ( $58^{\circ} \mathrm{S}$ and the prime meridian) to Capetown (35 ${ }^{\circ}$ and $18^{\circ} \mathrm{E}$ ). In order to provide a better lateral resolution for the large distances covered by this section, it has been divided into two segments: the southern seg-

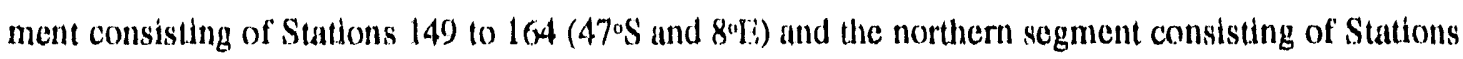
16410179 .

III.5-a) Southern Capetown-Weddell Section (Stations 149-164);

This segment represents a mertdional section for a latiludinal range from about $59^{\circ} \mathrm{S}$ to $46^{\circ} \mathrm{S}$. In the area south of about 51 "S, a well defined temperature minimum layer with sub-zero temperatures (about 100 meters thick, outlined by the $0.0^{\circ} \mathrm{C}$ contour in Fig. 40) is present around 200 meters deep. This appears to represent remnants of cold winter mixed layer water, which is, in turn, underlain by a warmer and more saline layer. The temperature minimum deepens north of about $52^{\circ} \mathrm{S}$ and disappears totally north of 50's (see Fig. 40) as described by Gordon (1971-b). In the area north of about $51^{\circ} \mathrm{S}$, the surface and intermediate waters are both several degrees warmer and the deep waters by $1^{\circ} \mathrm{C}$ compared to the southern half. The transition in surface water temperature takes place between $51^{\circ} \mathrm{S}$ and $52^{\circ} \mathrm{S}$ representing the polar front separating the subantarctic and antarctic waters (Gordon, 1971-b). A layer of warm $(2.3-3 .(10 \mathrm{C})$ and less saline $(34.0 \sim 34.3 \mathrm{o} / \mathrm{oo})$ water is found between 300 and 800 meters deep in the area north of 50 'S. This appears to represent the Antarctic Intermediate Water (AAIW), which is formed in this latitudinal range and spreads northward eventually beyond the equator. The potential temporature and salinity relationships are shown in Fig. 42.

In the southern half of this segment, there is a well defined temperature maximum which is centered around about 300 meters deep and outlined by the 1.0, 1.5 and $2.0 \% \mathrm{C}$ isotherms (Fig. 40), This temperature maximum layer is located above the salinity maximum layer (Fig. 41), which appears to be derived from the high salinity NADW depicted by the 34.75 and $34.78 \mathrm{o} / 00$ isohalines in the northern half of this section between $2(0)$ and $3(0) 0$ meters deep. The temperature maximum water has a $\sigma_{2}$ density of about 36.95 and adso is associated with a local maximum in the total $\mathrm{CO}_{2}, \mathrm{pCO}_{2}$, AOU, nitrate and phosplate and with a local minimum in the oxygen concentration. On the hasis of the density, temperature, salinity and odher chemical values (Tables 1 and 3), this water appears to rep)resent the upper Circumpolar Deep Water (Reid et al., 1977). Immediately below this, the saline 
TABLE - 3 Summary of the physical and chemical characteristics of various water masses observed during the Meteor 11/5 expedition in the South Athantic and northern Weddell Sea areas, The values represent extreme values observed during the expedition, but do not necessarily indicate the values for the "pure" end members of water mass, UCPDW $=$ Upper Circumpolar Deep Water; NADW $=$ North Atlantic Deep Water; L.CPDW = Lower Circumpolar Deep Water; CBHW = Cape Basin Bottom Water. $(+)$ and (-) signs indicate that the values listed comprise a local maximurn and minimum respecitvely,

\begin{tabular}{|c|c|c|c|c|}
\hline Watier Masges & UCPDWW & NADW & I.CPDW & CBBW \\
\hline Sections observed & Cape-Wedde11 & Cape-Wedde11. & Cape-Weddel1 & Cape-Wedde11. \\
\hline stat tons & $158-161$ & $17 \%-178$ & $152-154$ & $176-179$ \\
\hline Depths (meters) & $1.000-1500$ & $2000-3000$ & $1200-1700$ & $=4400$ \\
\hline Pot, 'l'omp, $\left({ }^{\circ} \mathrm{C}\right)$ & $2.0-2.5$ & $2.0-2.5$ & $0.2-0.3$ & $<0.6$ \\
\hline Saltntty $(0 / 00)$ & $34.5-34.7$ & $34.80-34.85(+)$ & $34.68-34.70$ & $<34.73$ \\
\hline Denloty $\left(\sigma_{1}\right)$ & $27.74-27.80$ & $27.80-27.84$ & $27.82-27.84$ & $>27.85$ \\
\hline Dentsity $\left(\sigma_{2}\right)$ & $36.7-36.9$ & $36.95-37.05$ & $37.07-37.13$ & $>37.13$ \\
\hline $\mathrm{TCO}_{2} \quad(\mathrm{uM} / \mathrm{kg})$ & $2220-2250(+)$ & $2200-2210(-)$ & $2260(+)$ & $>2250$ \\
\hline $\mathrm{PCO}_{2}$ \& $20^{\circ} \mathrm{C}$ (uatm) & $1100-1180(+)$ & $850-900(-)$ & $1100-1125(+)$ & $>1010$ \\
\hline $\mathrm{O}_{2} \quad\langle\mathrm{UM} / \mathrm{kg}\rangle$ & $180-200(-)$ & $220-230(t)$ & $210-220$ & $\therefore 219$ \\
\hline AOU (UM/kg) & $140-150(+)$ & $100-110\langle-\rangle$ & 135 & 125 \\
\hline $\mathrm{NO}_{3} \quad(\mathrm{uM} / \mathrm{kg})$ & $34-35(t)$ & $2.5-26(-)$ & $33-34$ & $>31$ \\
\hline $\mathrm{PO}_{4} \quad(u M, k g)$ & $2.4-2 \cdot 5(+)$ & $1.7-1.8(-)$ & 2.3 & 2.1 \\
\hline $\mathrm{SLO}_{3} \quad(\mathrm{HM} / \mathrm{kg})$ & $70-80$ & $50-60(-)$ & $120-127$ & $\times 108$ \\
\hline TALK (UEq/kg) * & $2335-2.340$ & $2.335-2.340$ & 2360 & $>2370$ \\
\hline Fot. NLK (UEG/kg)** & $2400(+)$ & $2378(-)$ & $2415-2417$ & $>2420$ \\
\hline
\end{tabular}

* Total alkalinity ('IALK) values computed usting the total $\mathrm{CO}_{2}$ concentration and $\mathrm{pCO}_{2}$ \& $20^{\circ} \mathrm{C}$ data at observed salinities.

**/ Potential alkalinlty (Pot. ALK) computed as $\left[(' \mathrm{I} A \mathrm{LK})+\left(\mathrm{NO}_{3}-\right.\right.$ ) 1 and normalized to a balintty of $35.000 / 00$. 


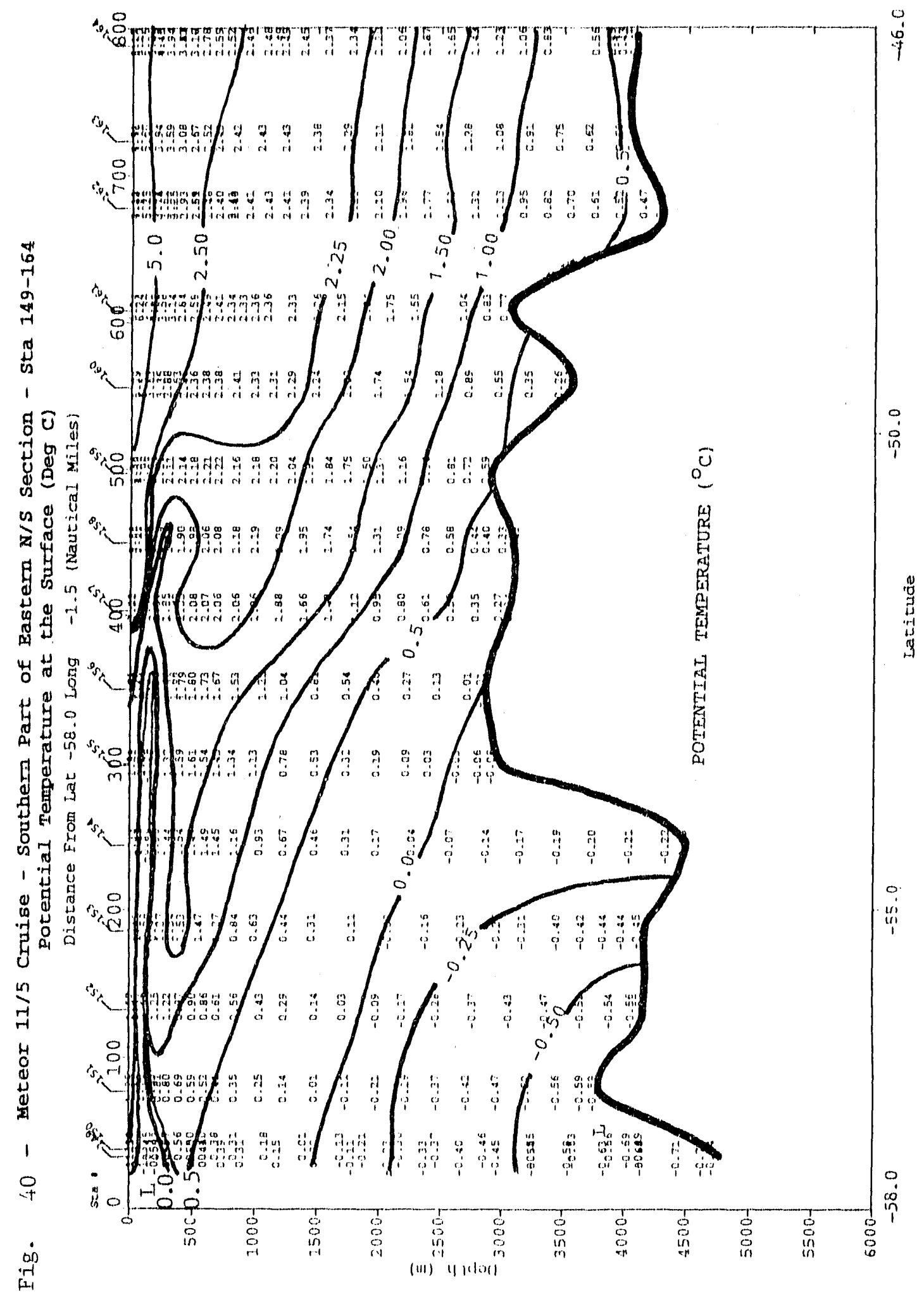




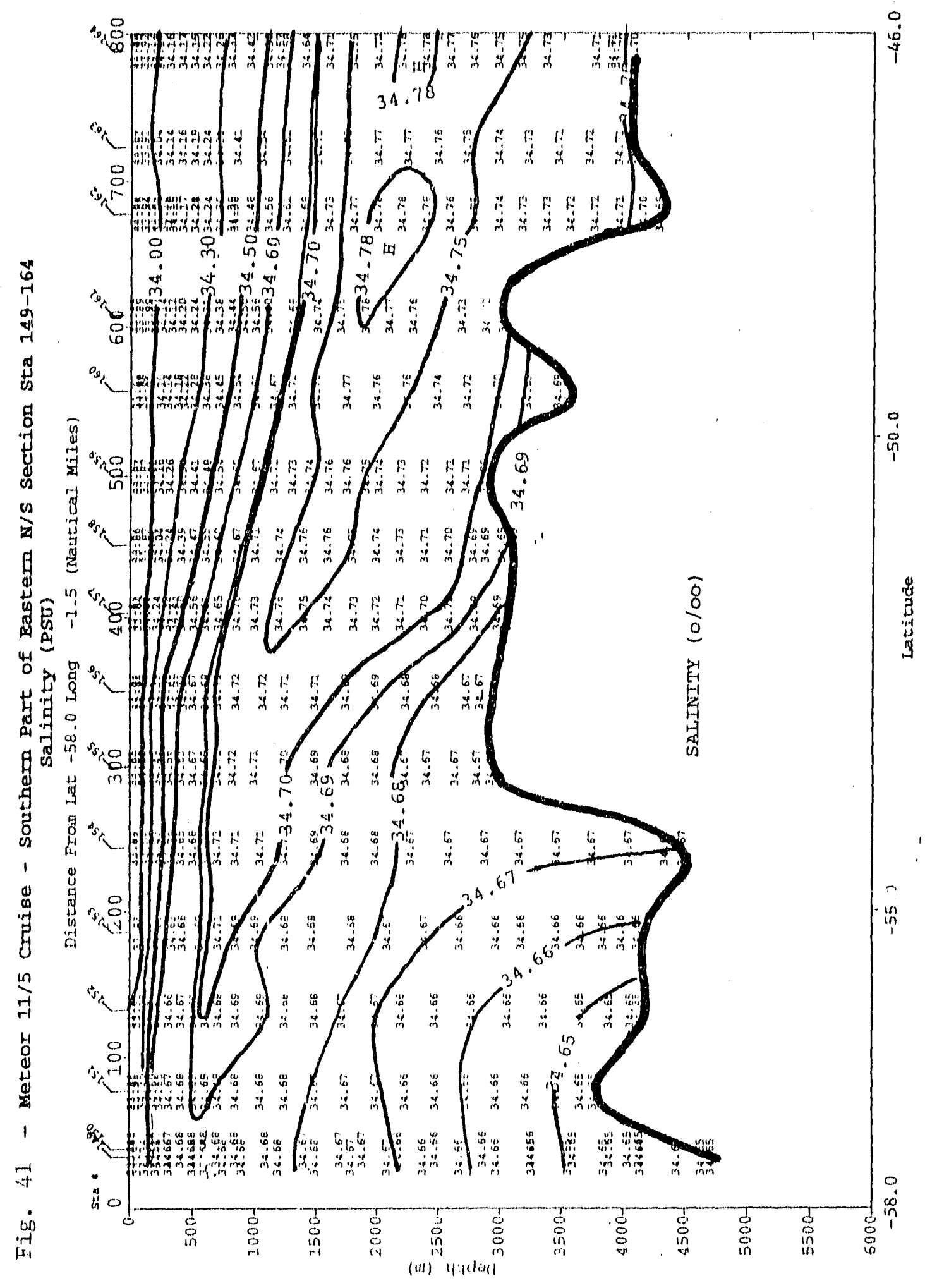


F.L. 42 - potenttal temperaturemsalintty relationships obaerved In the Capetown-Wedde11. Sea section (southern segment). AATW = Antarctic Lntermedtate Water; NADW = North At lantic Deep Water; CPIJW $=$ CiLcumpolar Deep Water; $A A B W=$ Antarctic: Bottom Water; WSBW $=$ Weddell Sea Bottom Water.

F/S Meteor Cruise 11/5

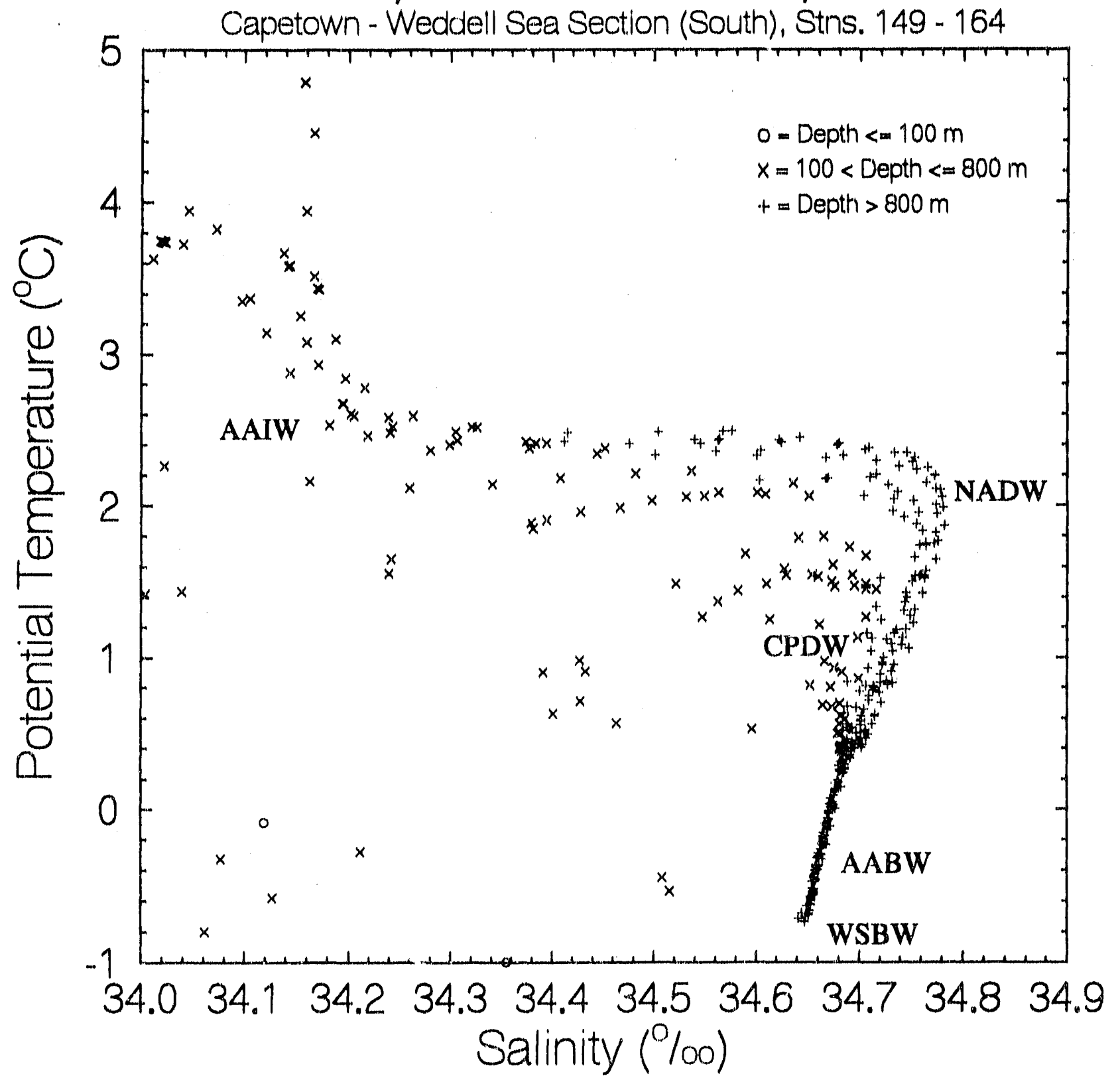


North Atlantic Deep Water (NADW) is found. It appears to intrude southward as indicated by the long upward extension of the 34.70 and $34.69 \mathrm{o} / 00$ isohaline contours (Fig. 41). At the northernmost station, Stn. 164, in this section, the NADW has a $\sigma_{2}$ density range of 36.96 to 37.05 (Fig. 43) and is characterized by a minimum in $\mathrm{TCO}_{i}$ (about $\left.2230 \mathrm{uM} / \mathrm{kg}, \mathrm{Fig} .44\right), \mathrm{pCO}_{2}(980$ to $1000 \mathrm{uatm}, \mathrm{Fig} .45)$, AOU (130 uM/kg, Fig. 47), nitrate (29 30 uM/kg, Fig. 48) and phosphate $(2.0 \mathrm{uM} / \mathrm{kg}$, Fig. 49). Because of the similarity in densities, it appears that the NADW mixes with the Circumpolar Water and thus is responsible for the high salinity values of the latter.

Below the NADW, a layer of colder and lower salinity water is present. This gives an appearance of the NADW wedging itself between the two layers of the Circumpolar Deep Water. This feature can be best illustrated in Figs. 44 and 45 by the $\mathrm{TCO}_{2}$ and $\mathrm{pCO}_{2}$ contours seen between 300 and 2000 meters deep in the southern (i.e. left) half of this section. Based upon the distribution of oxygen and phosphate in the western South Atlantic and Scotia Sea, Reid et al. (1977) observed splitting of the Circumpolar Deep Water into two branches above and below the NADW and named the Upper and Lower Circumpolar Deep Water. The chemical characteristics of these water masses are summarized in Table 3.

The waters below about 3000 meters in the southern half of this segment is dominated by the Antarctic and Weddell Sea waters, i.e. as cold as $-0.71^{\circ} \mathrm{C}$ and as fresh as $34.65 \mathrm{o} / 00$. They are characterized by relatively low $\mathrm{TCO}_{2}(2245 \mathrm{uM} / \mathrm{kg}), \mathrm{pCO}_{2}(1050 \mathrm{uatm}), \mathrm{AOU}(105 \mathrm{uM} / \mathrm{kg})$ values and high oxygen values $(255 \mathrm{uM} / \mathrm{kg})$, indicating strong influence of the Weddell Bottom Water. 


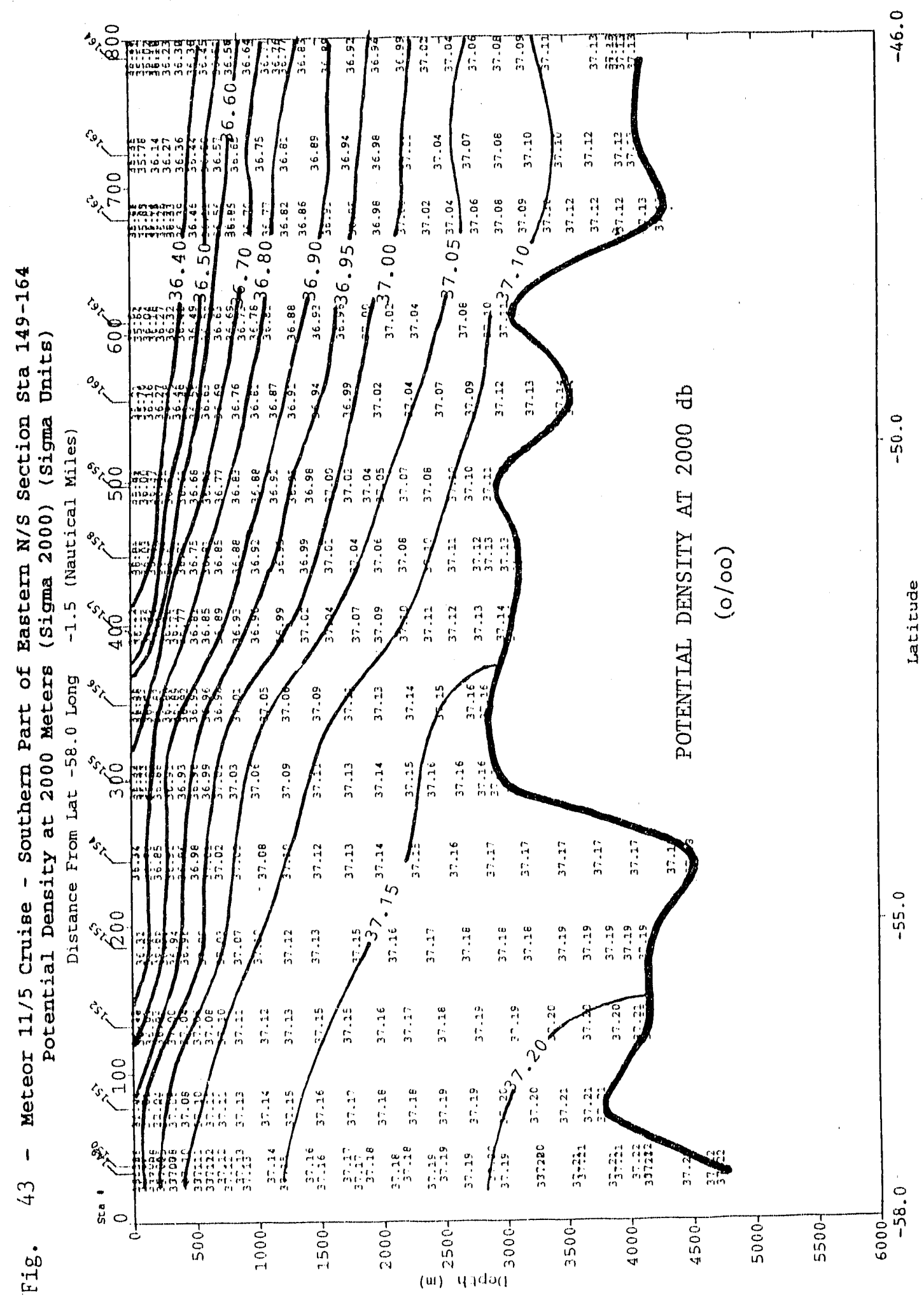




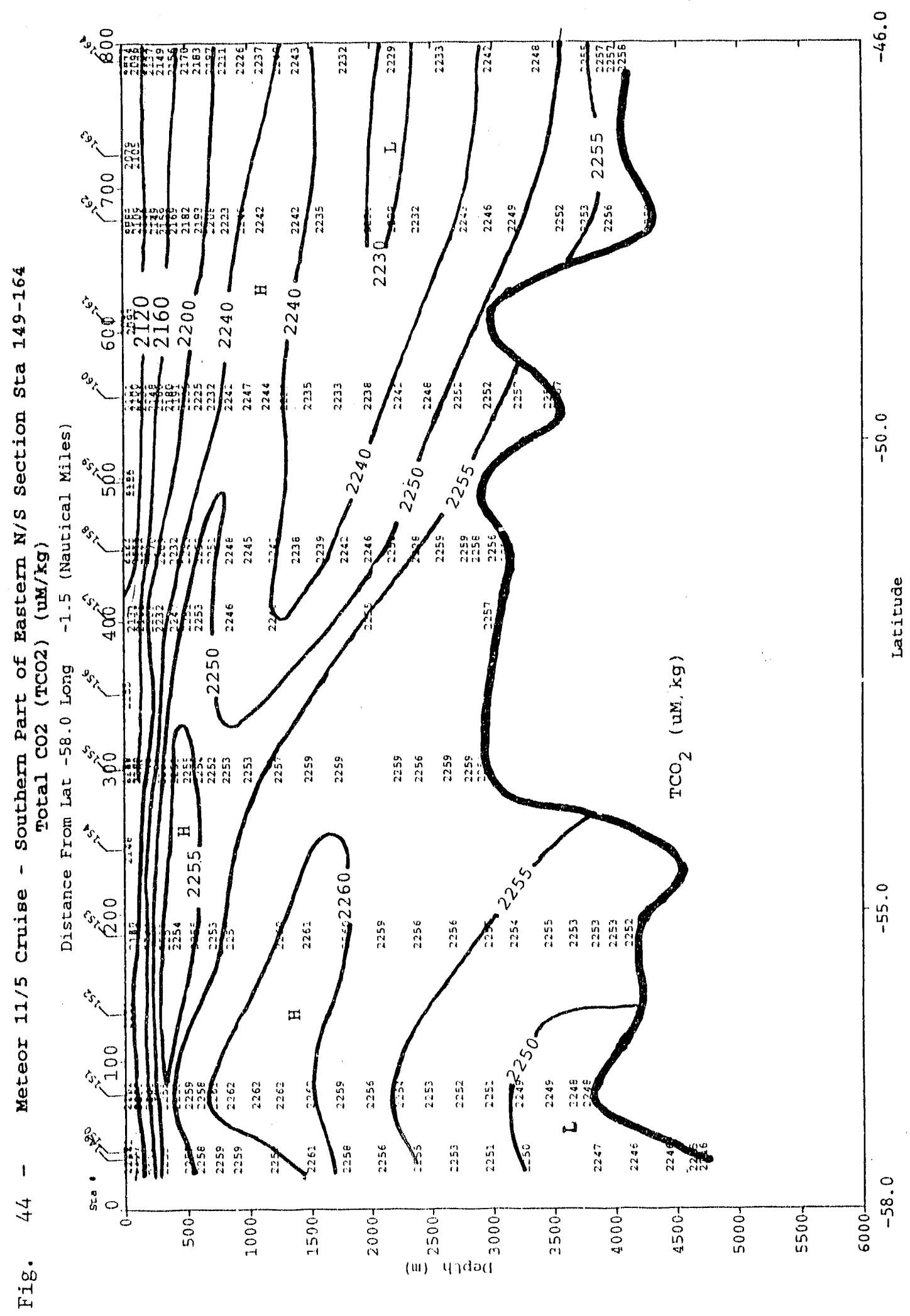




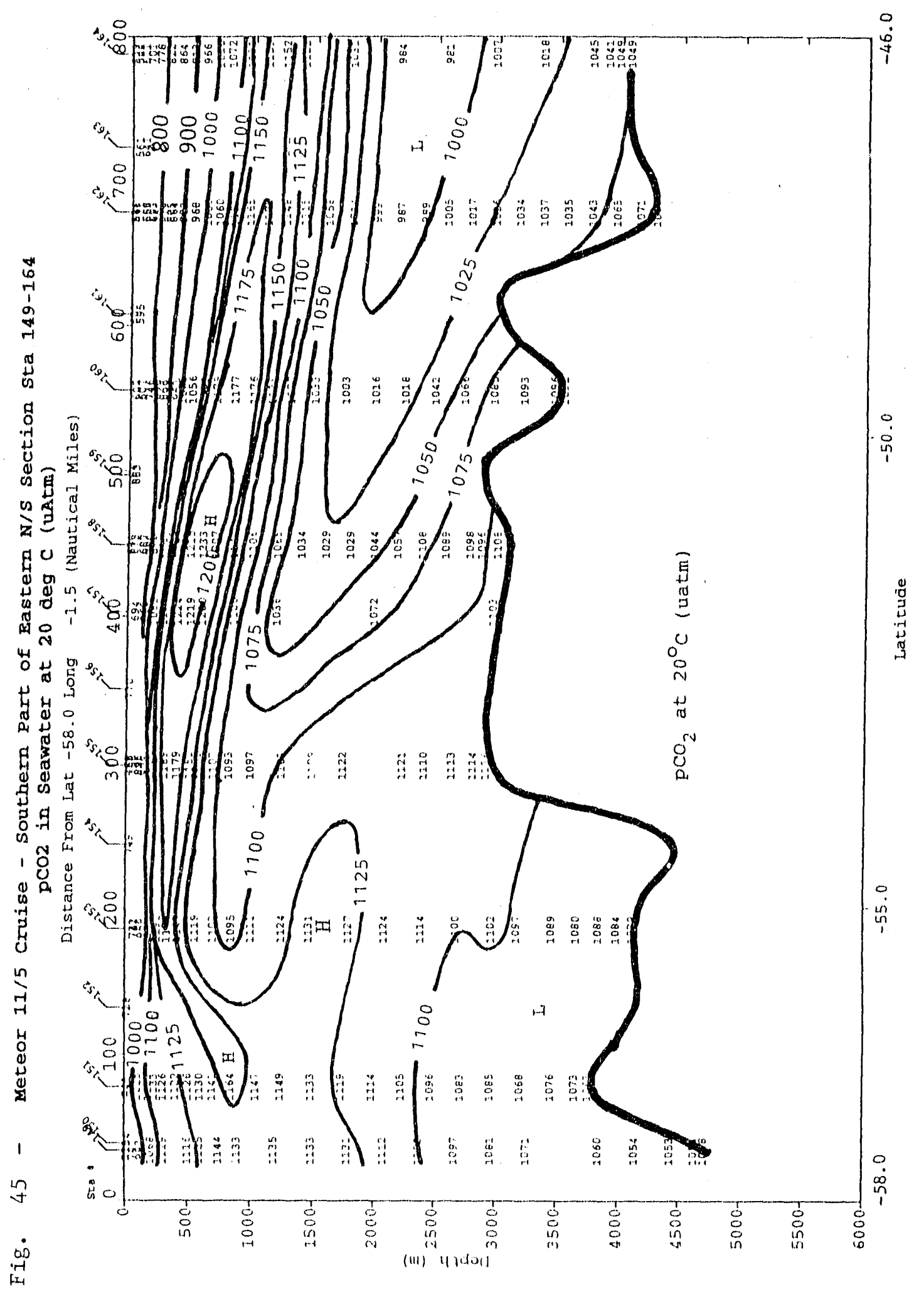

C 


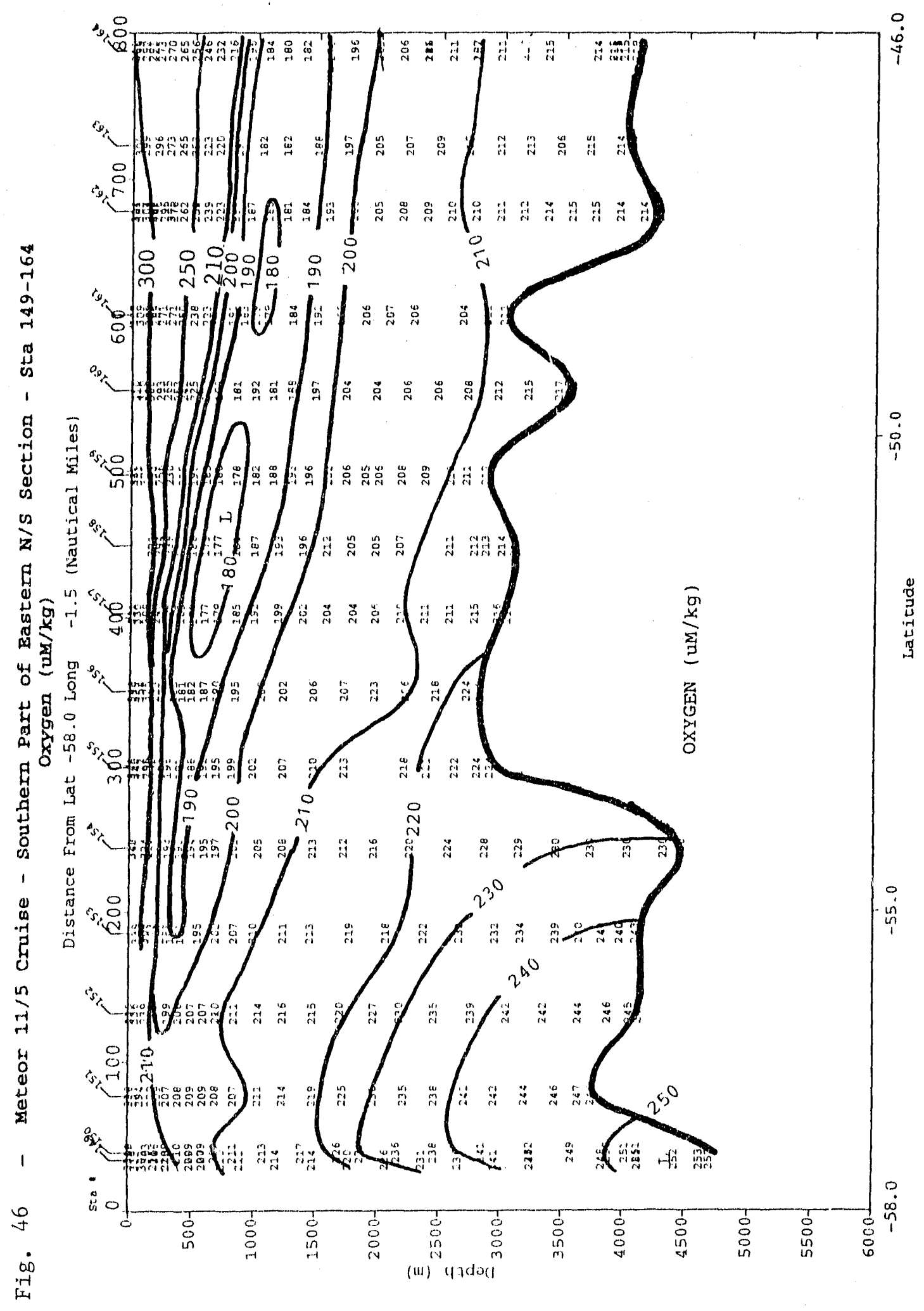




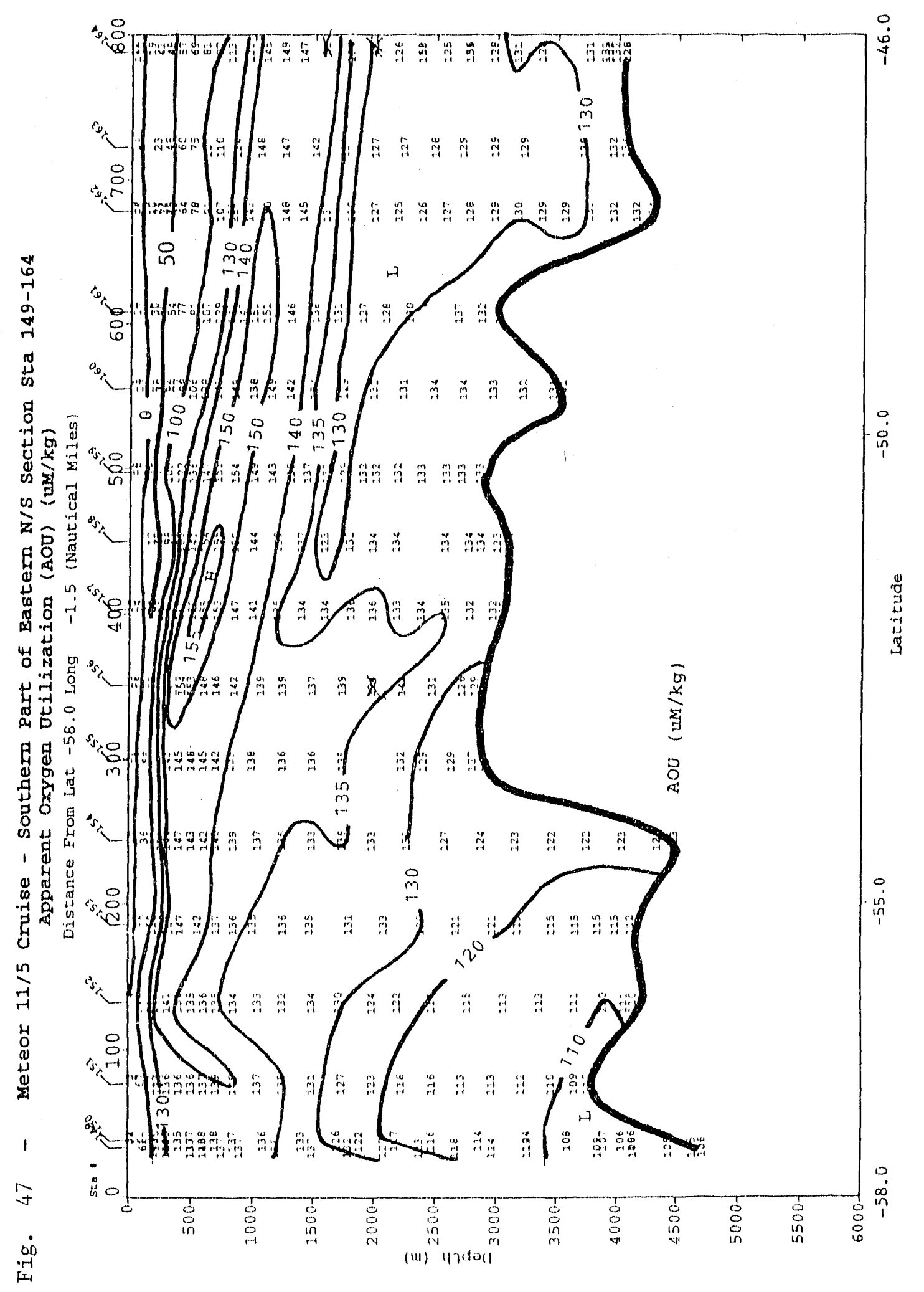




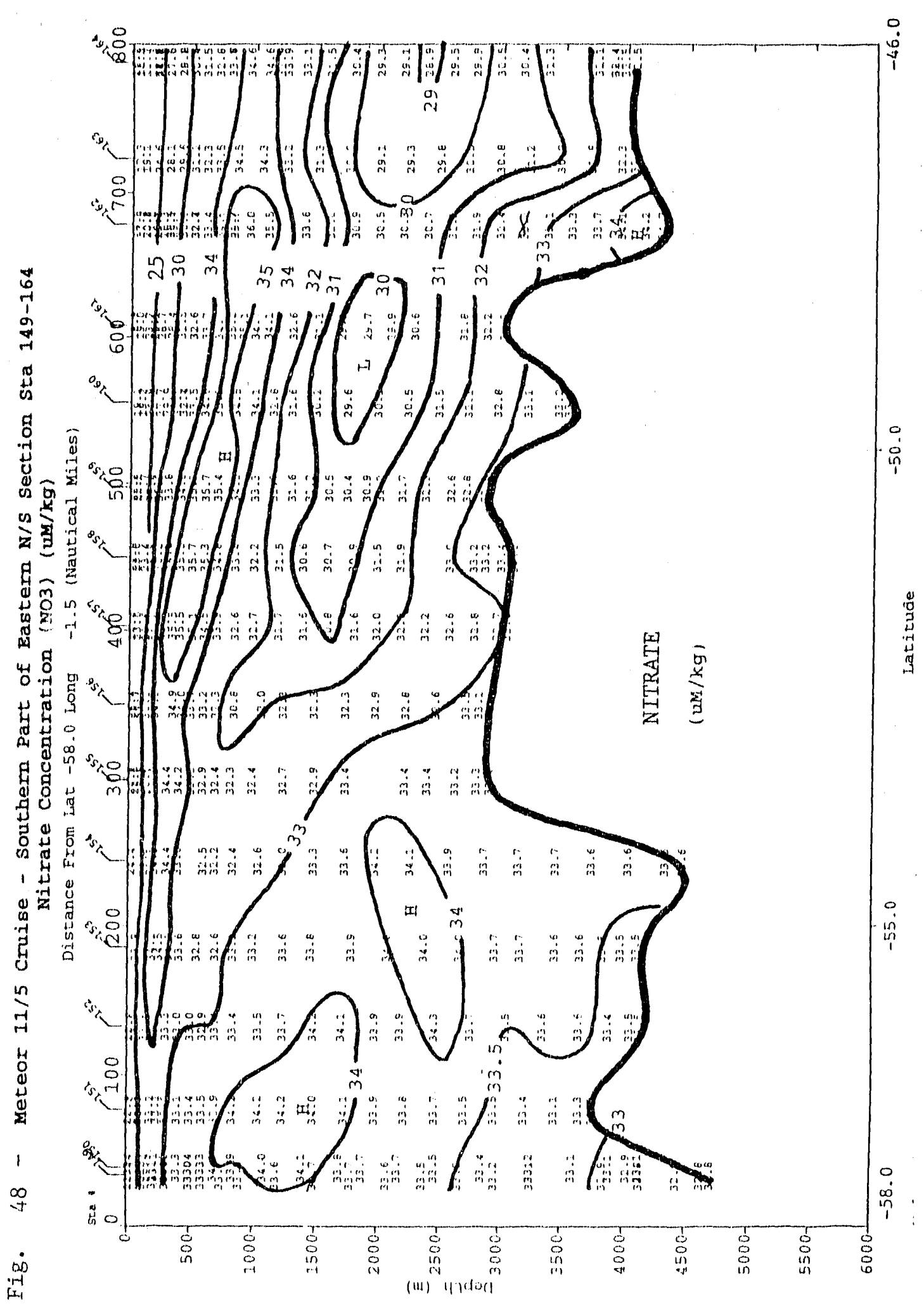




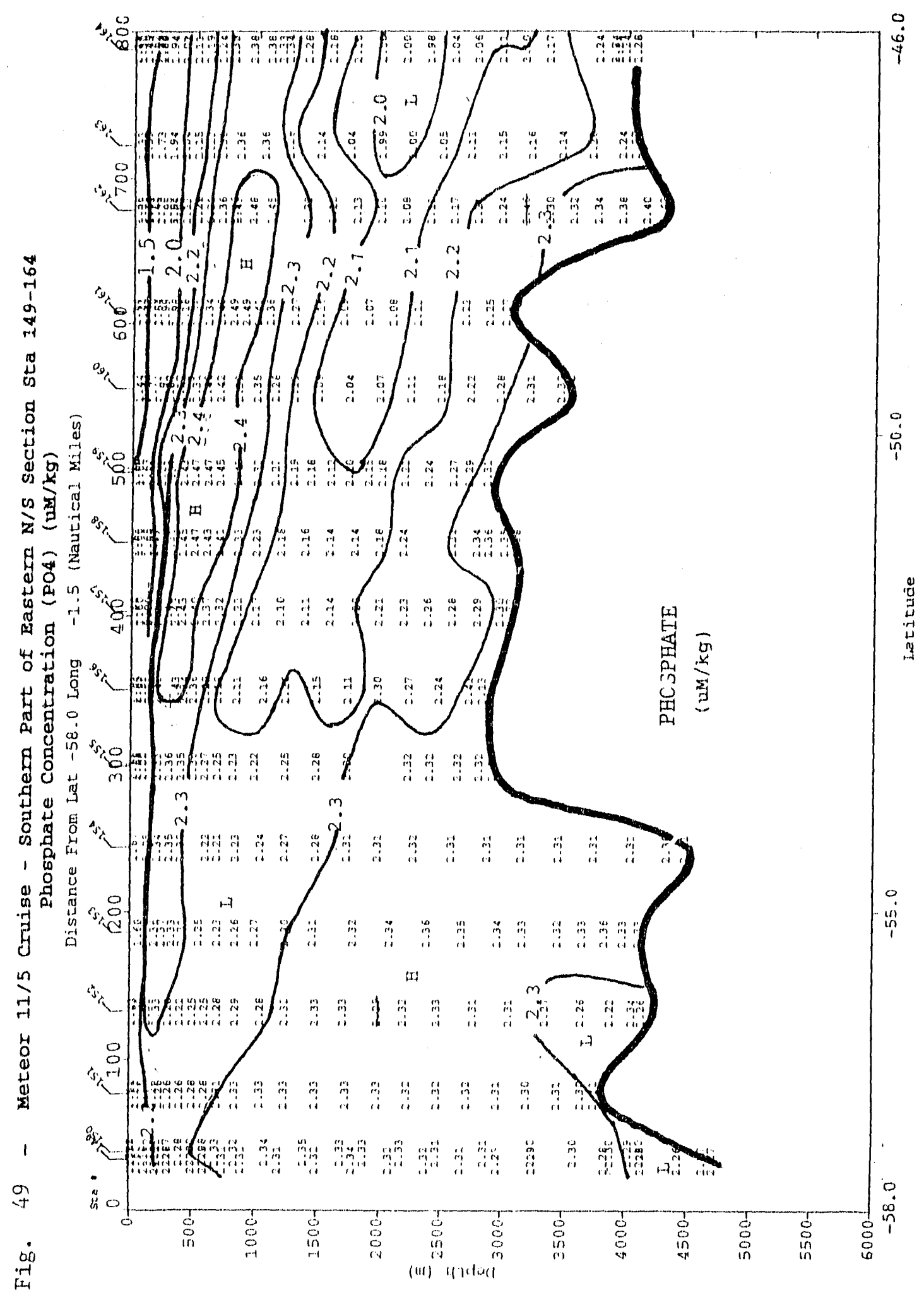

C 


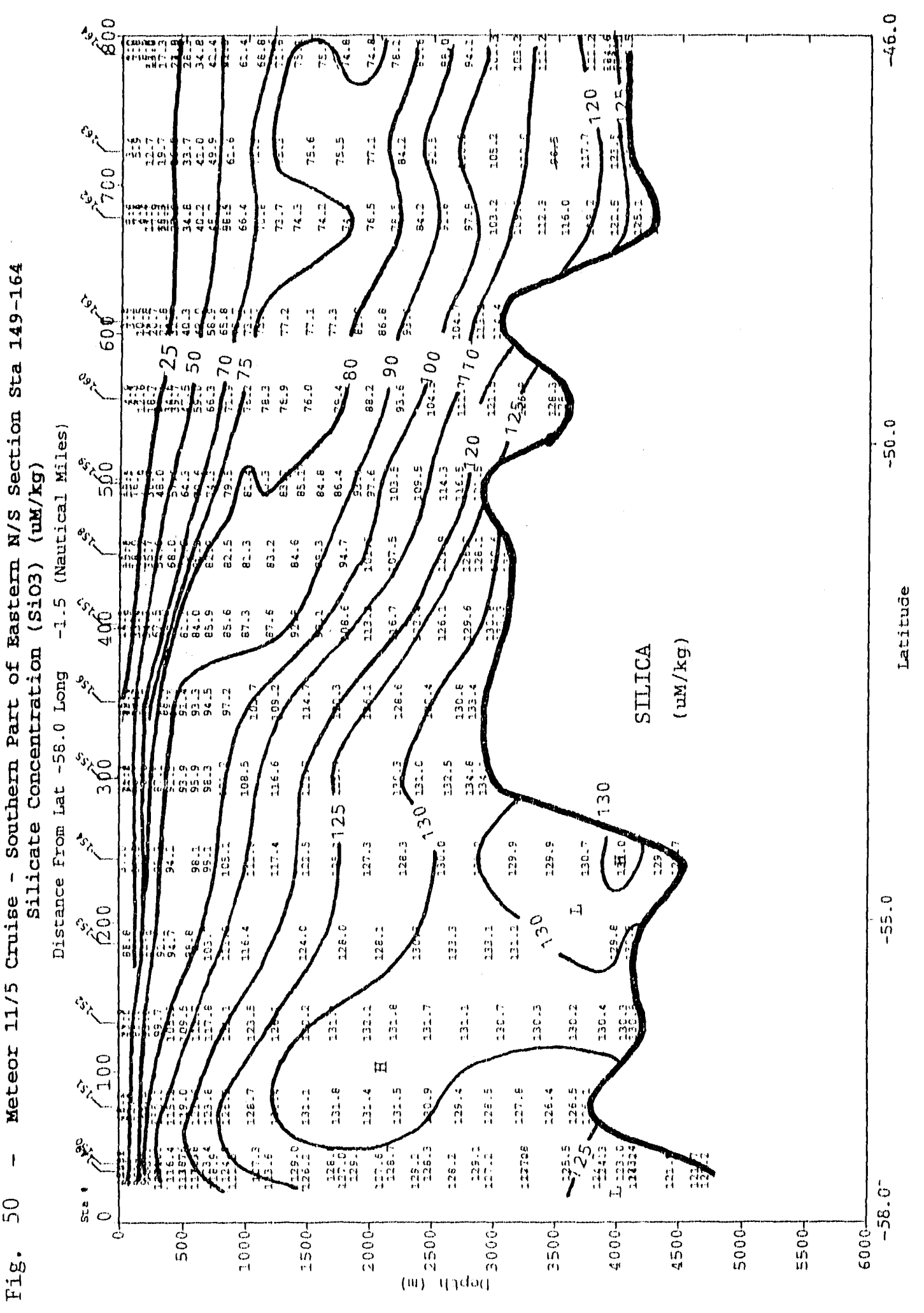


III-5-b) Northern Capetown-Weddell Section (Stations 164-179):

This segment covers a latitudinal range from $46 " S$ to $370 \mathrm{~S}$ in the eastern South Atlantic Ocean. The temparature and salinity both continue to lncrease northward ranging from about $0.5^{\circ} \mathrm{C}$. and 34.7 $0 / 00$ near the southemmost sea floor to $20 \mathrm{C}$ and $3.5 .5 \mathrm{o} / \mathrm{oo}$ for the northermmost surface wators, In the upper $10(0)$ meters, the Antaretie Intermediate Water (AAIW) is shown with a salinity minimum which is clearly outlined with the 34.3 and $34.40 / 60$ isohalines contered around 500 meters deep near 45 'S and $1\left(O(X)\right.$ meters deep near $37.5^{\circ} \mathrm{S}$. The tomperature for the $A A I W$ ranges from about 3 to $5^{\circ} \mathrm{C}$. However, this water mass does not exhibit local minima or maxima in other properties besides the salinity. Immediately below the AAIW, there exists a layer of water with a temperature of about $2.5^{\circ} \mathrm{C}$ and a salinity of $34.6 \mathrm{o} / 00$ at a depth of about $150\left(\right.$ ) meters. It has a $\sigma_{2}$ density between 36.8 and 36.9 (Fig, 54). While this layer does not show a local maximum or minimum in sulinity or temperature, it exhibits a clear minimum in the oxygen concentration (ses the 180 and $190 \mathrm{uM} / \mathrm{kg}$ contours in Fitg. 57) and a clear maximum in the total $\mathrm{CO}_{2}$ concentration (see the 2230 and $2240 \mathrm{uM} / \mathrm{kg}$ contours in Fig. 55), $\mathrm{pCO}_{2}$ (see the $110(1)$ and 1150 uatm contours in Fig. 56), AOU (sec the $140 \mathrm{uM} / \mathrm{kg}$ contours in Fig. 58), nitrate (see the 33 and $34 \mathrm{uM} / \mathrm{kg}$ contours in Fig. 59), phosphate (see the 2.2 and 2.3 uM/kg contours in $\mathrm{Fig} .60$ ). On the othor hand, the silicate concentration (Fig. 61) does not exhibit an extremum at these depths, and ranges between 68 and $73 \mathrm{uM} / \mathrm{kg}$. Since these features match with those for the Upper Circumpolar Deep Water (UCPDW) listed in Table 3, this layer is identified as UCPDW. In the eastern basin of the South Allantic, this water mass has been traced as far north as $20^{\circ} \mathrm{S}$ or equatorward of the Rio (irande Rise) (see page 70 in Reid et al, 1977). Our study in the eastarn Atlantic shows that the UCPDW also extends further north beyond $37^{\circ} \mathrm{S}$.

The deep regime is dominated by the North Atlantic Deep Water (NADW) which is characterized by a salinity maximum outlined with the 34.80 and $34.850 / 00$ contours. The NADW exhibits a maximum in the oxygen concentration (see 220 and $230 \mathrm{uM} / \mathrm{kg}$ contours in Fig. 57) and a minimum in the total $\mathrm{CO}_{2}$ concentration (see 2210 contour in Fig. 55), $\mathrm{pCO}_{2}$ (see 850 and 900 ) uatm contours in Fig. 56), AOU (see $1(x)$ and $110 \mathrm{uM} / \mathrm{kg}$ contours in Fig. 58), nitrate (see 25 and $26 \mathrm{uM} / \mathrm{kg}$ contours), phosphate (see 1.7 and $1.8 \mathrm{uM} / \mathrm{kg}$ contours in Fig. 6()) and silica (see 6) and 7() $\mathrm{uM} / \mathrm{kg}$ contours in Fig. 61). These chemical properties are summarized in Table 3 and the potential temperature-salinity relationships observed in this section are shown in Fig. 53. 


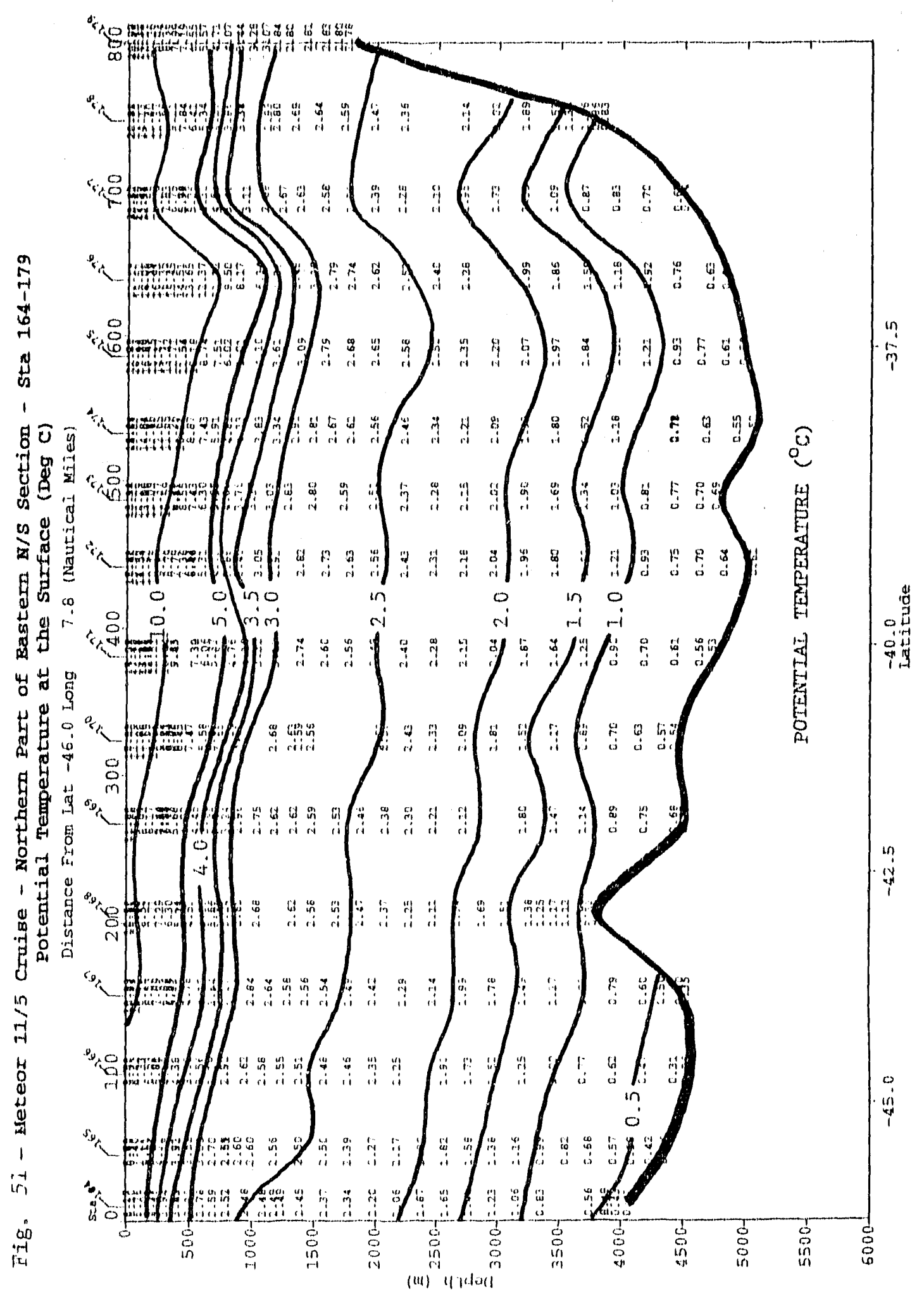




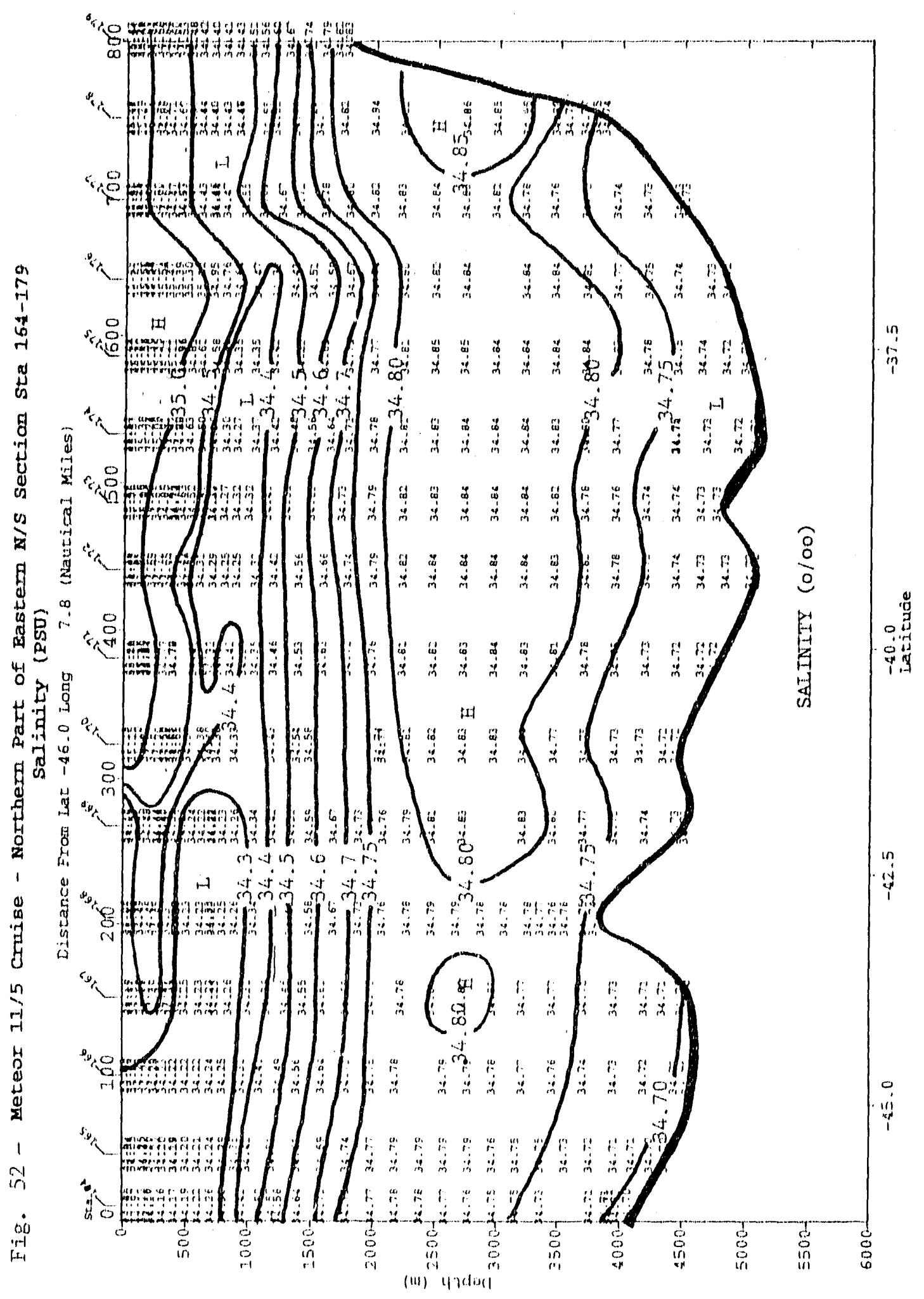


WL. 53 - Potential temperaturemsaldndty redationships observed In the Capetown-Wedde1.1. Sea section (northern segment). AAJW a Antarctic Intermedtate Water; NADW a North Atlantilc Deep Water; $A A B W=$ Antarcto Bottom Water.

F/S Meteor Cruise 11/5

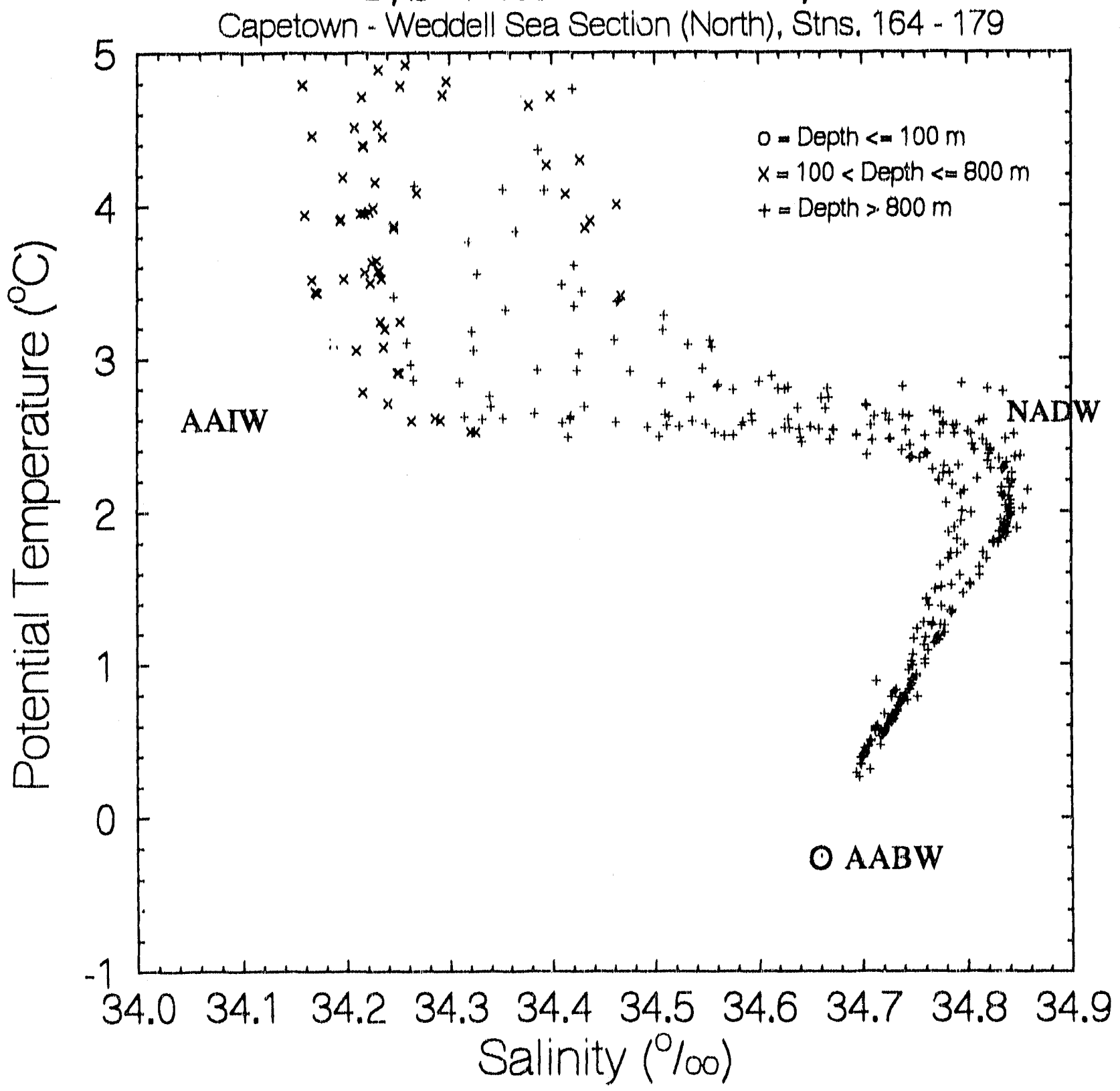




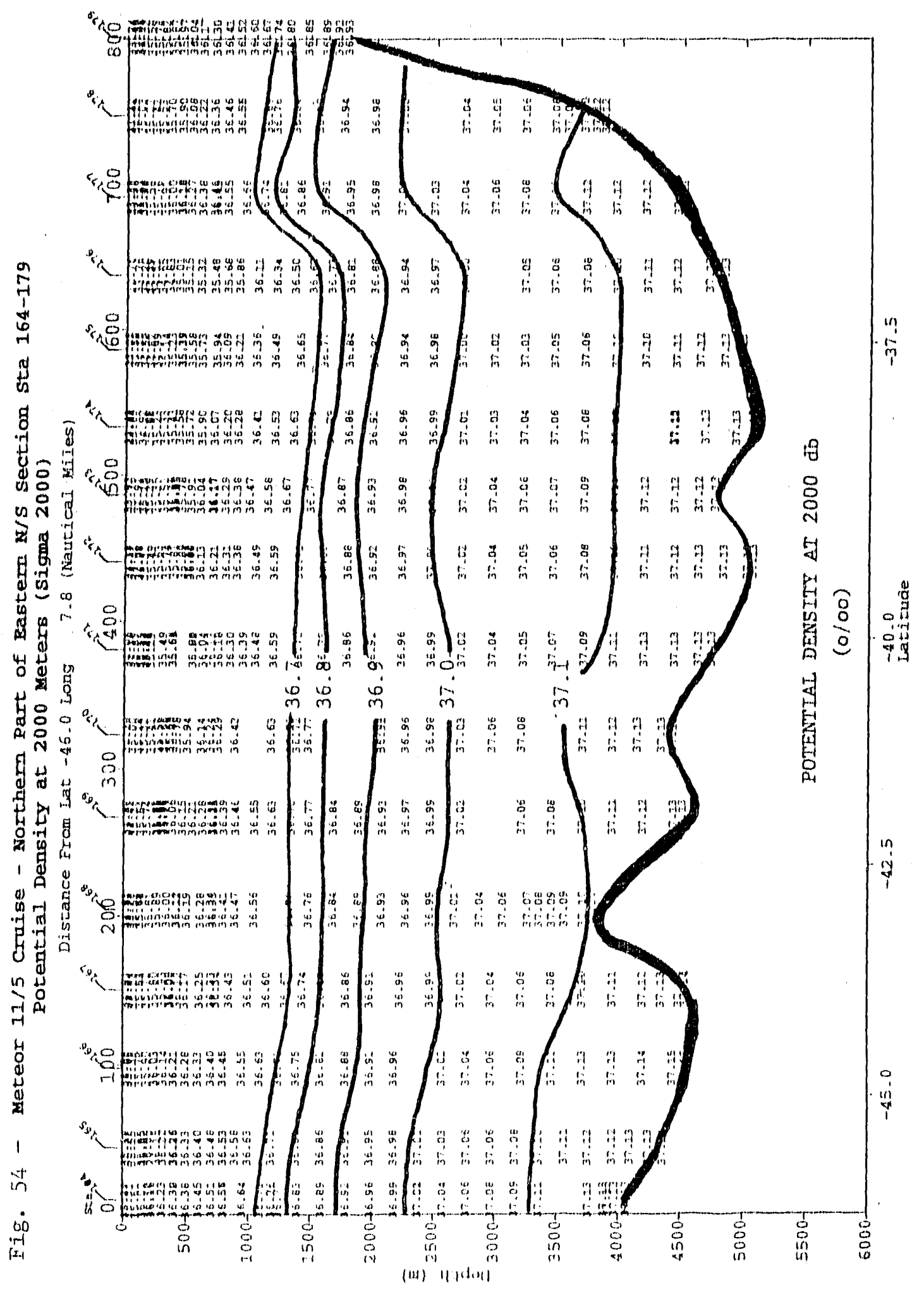

C 


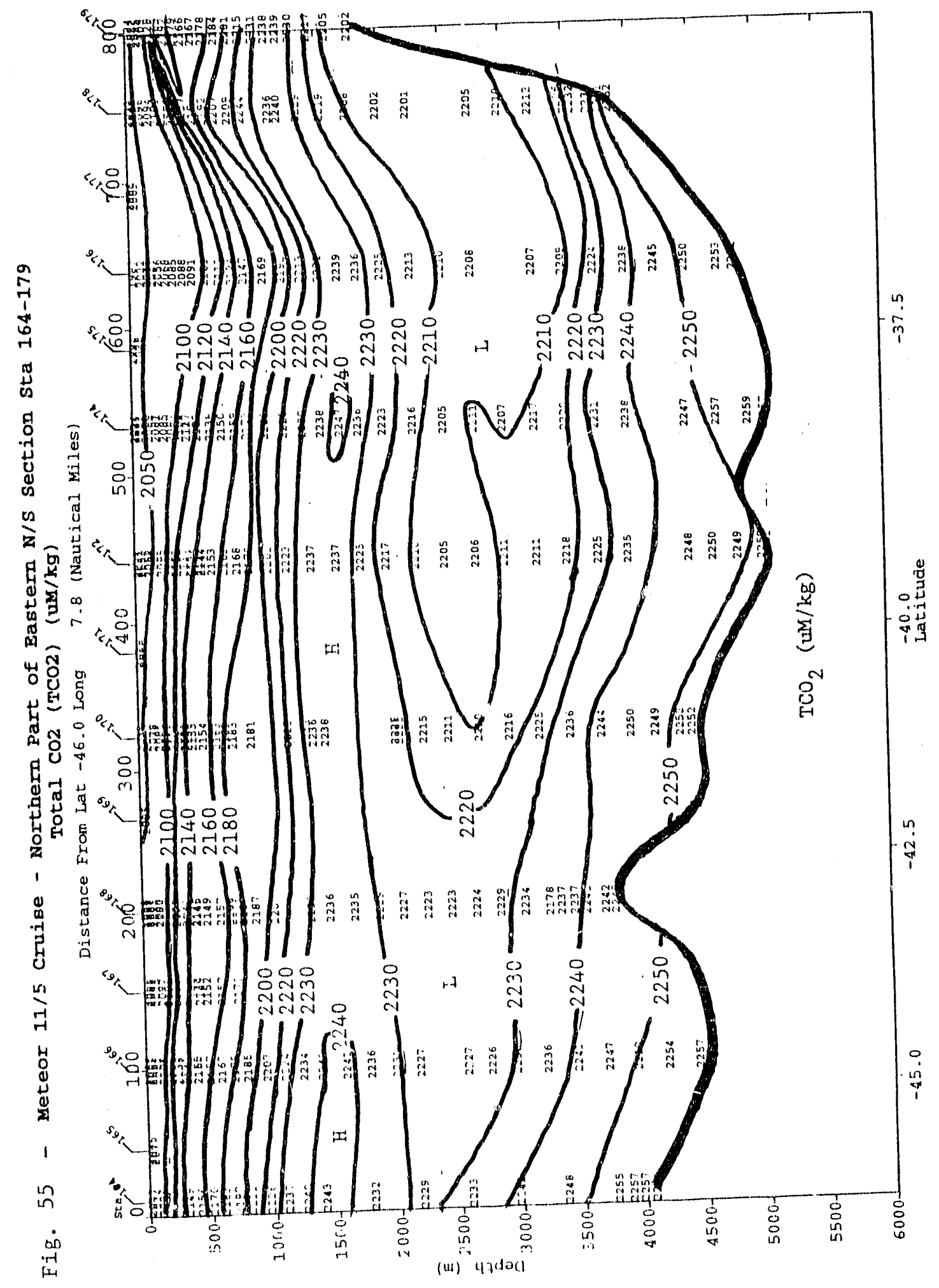




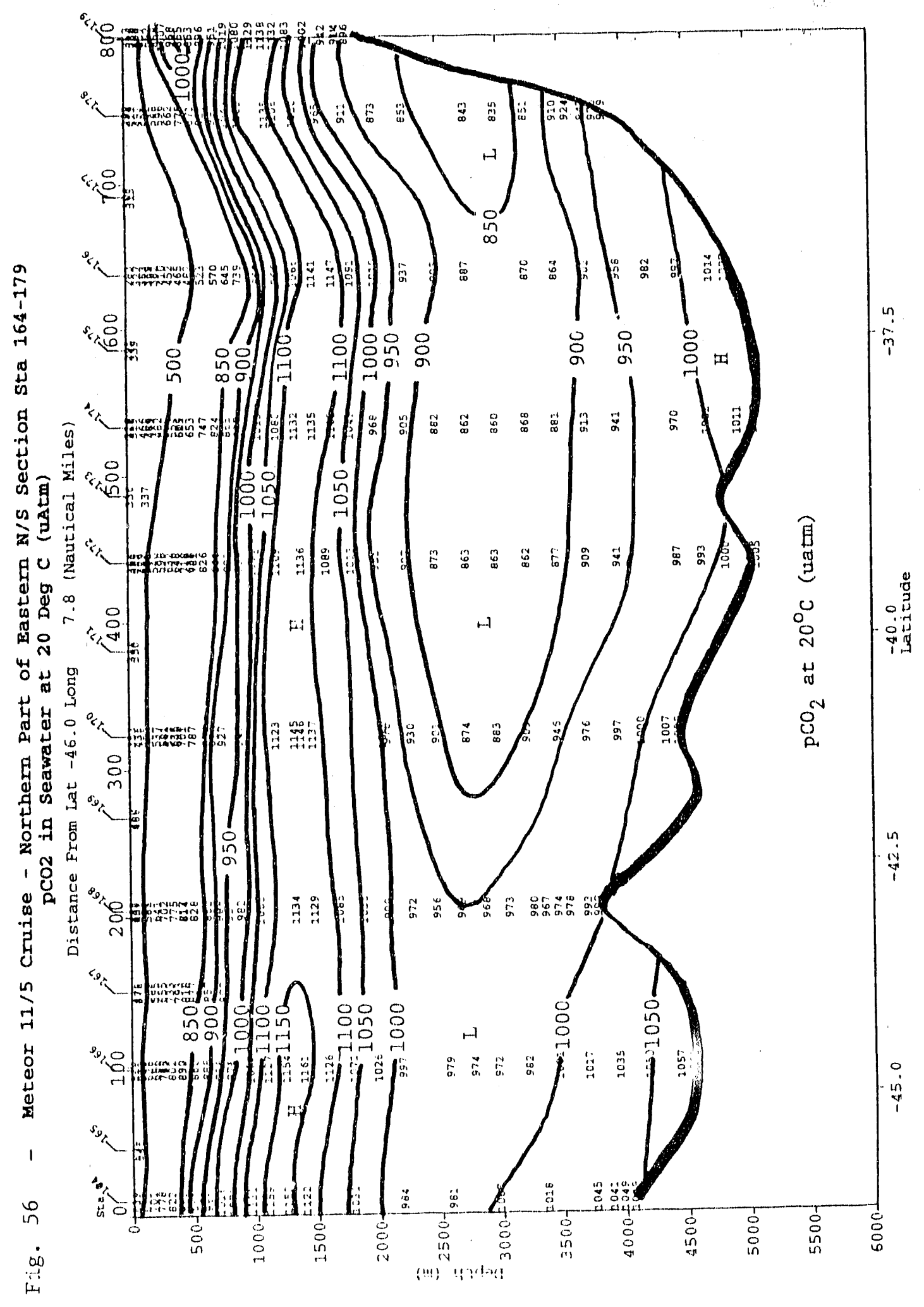




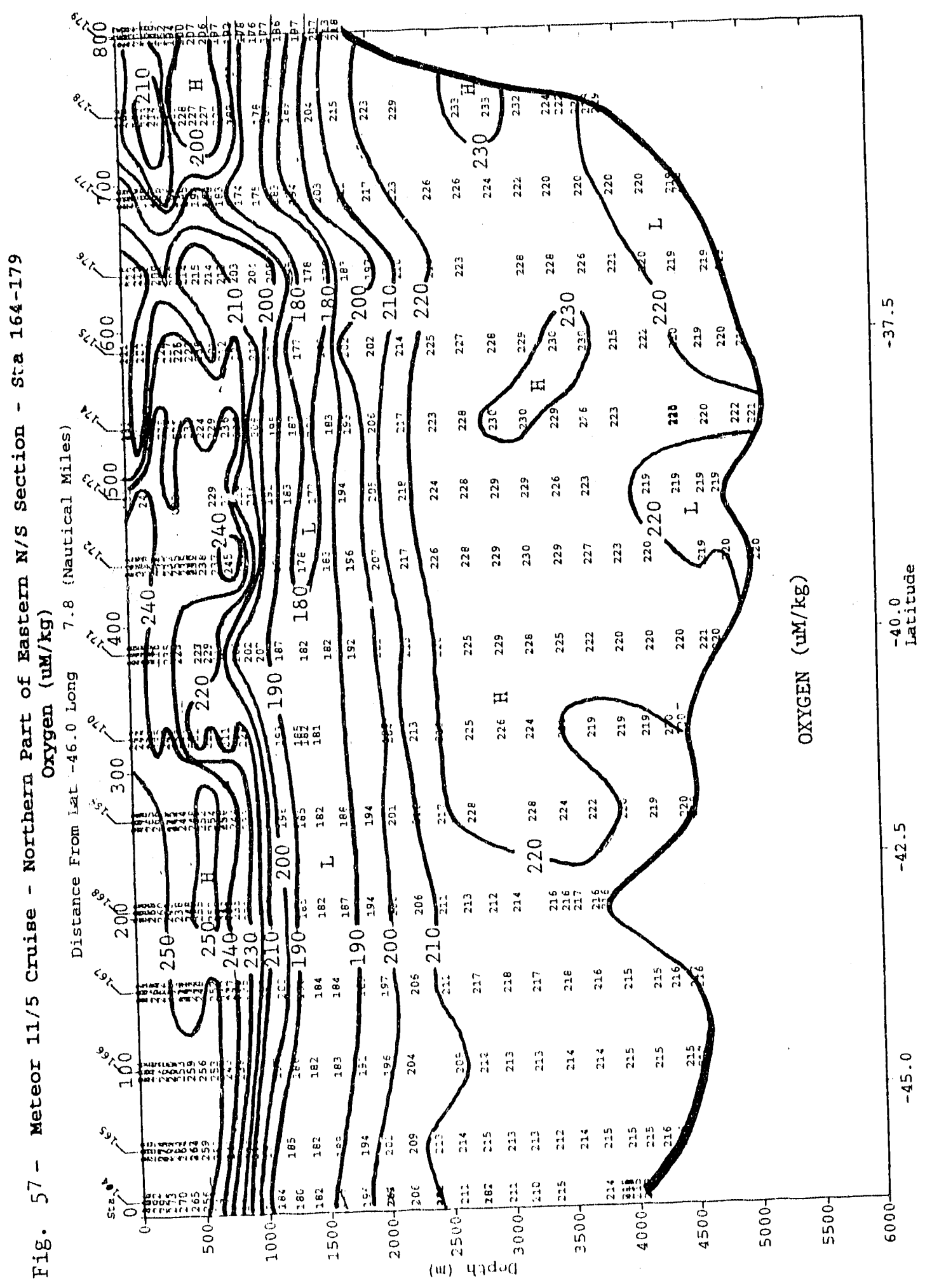




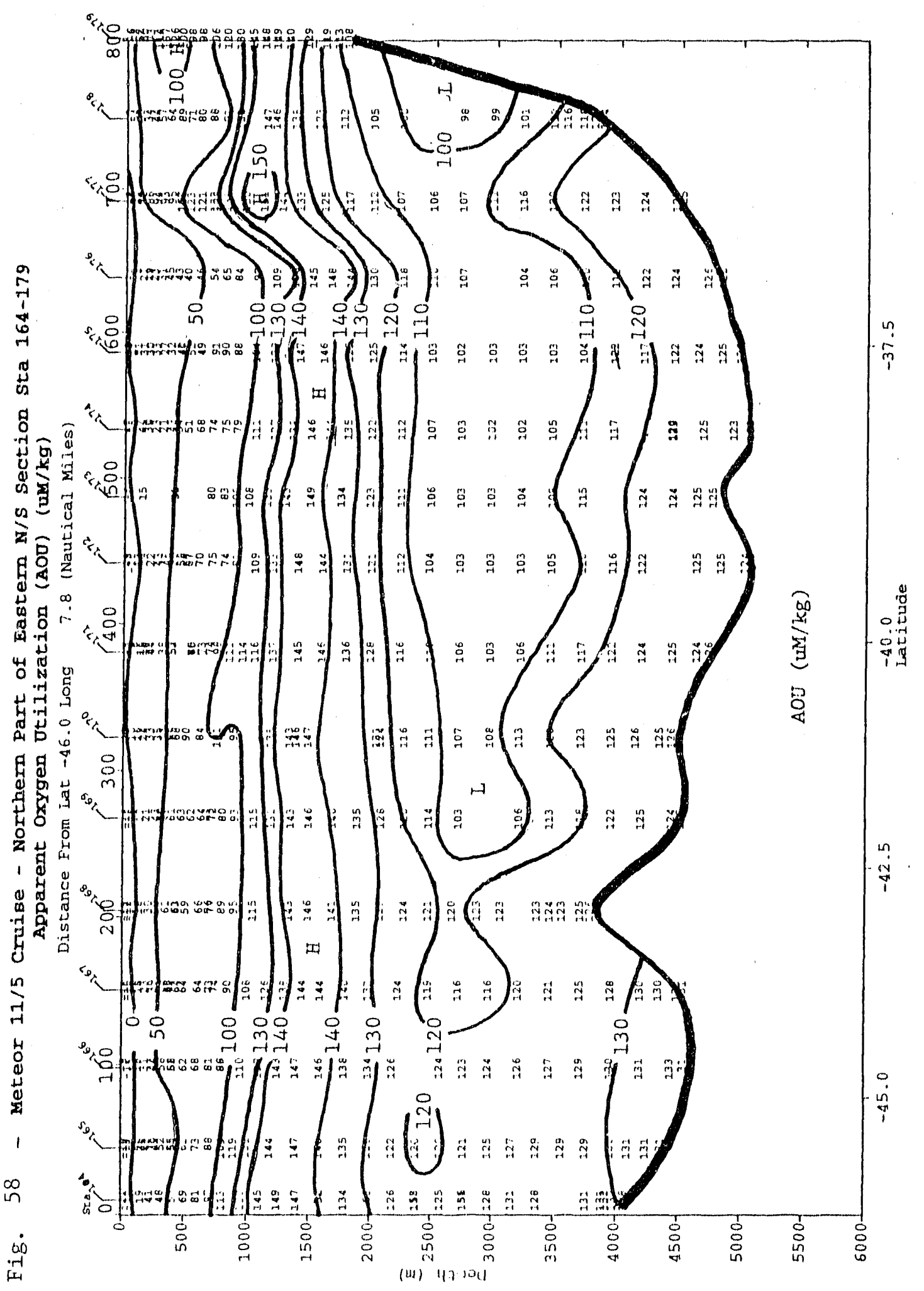




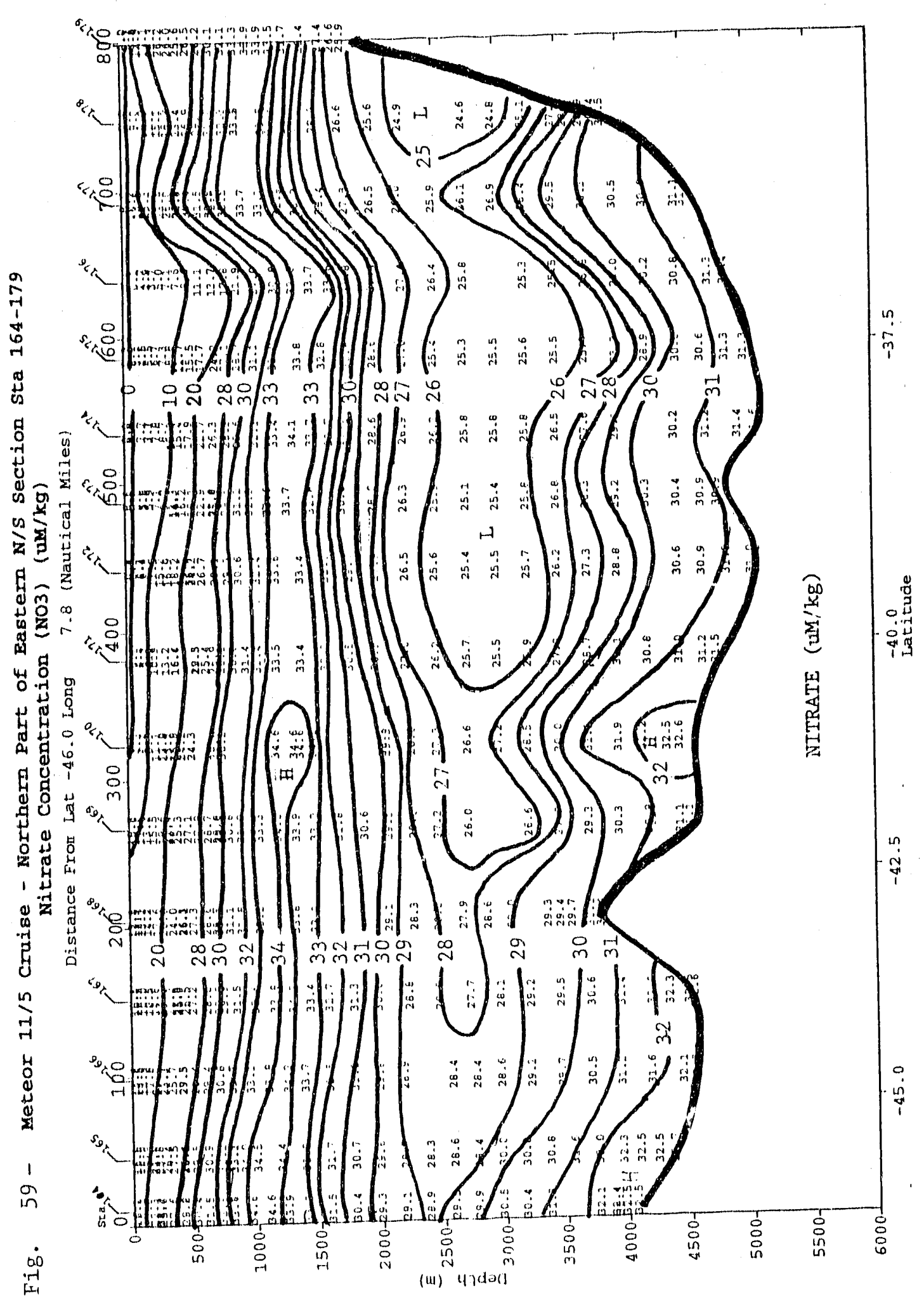




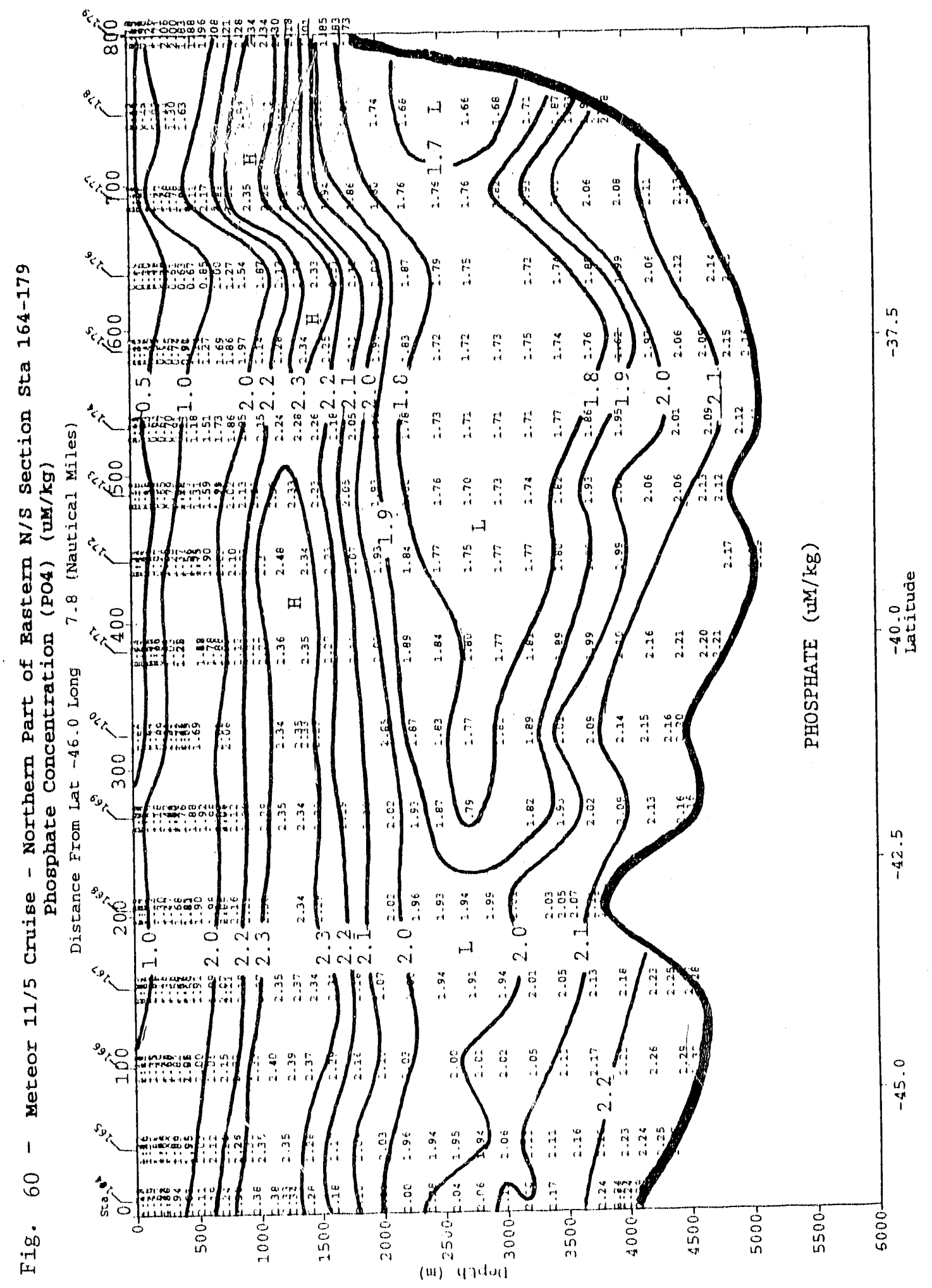




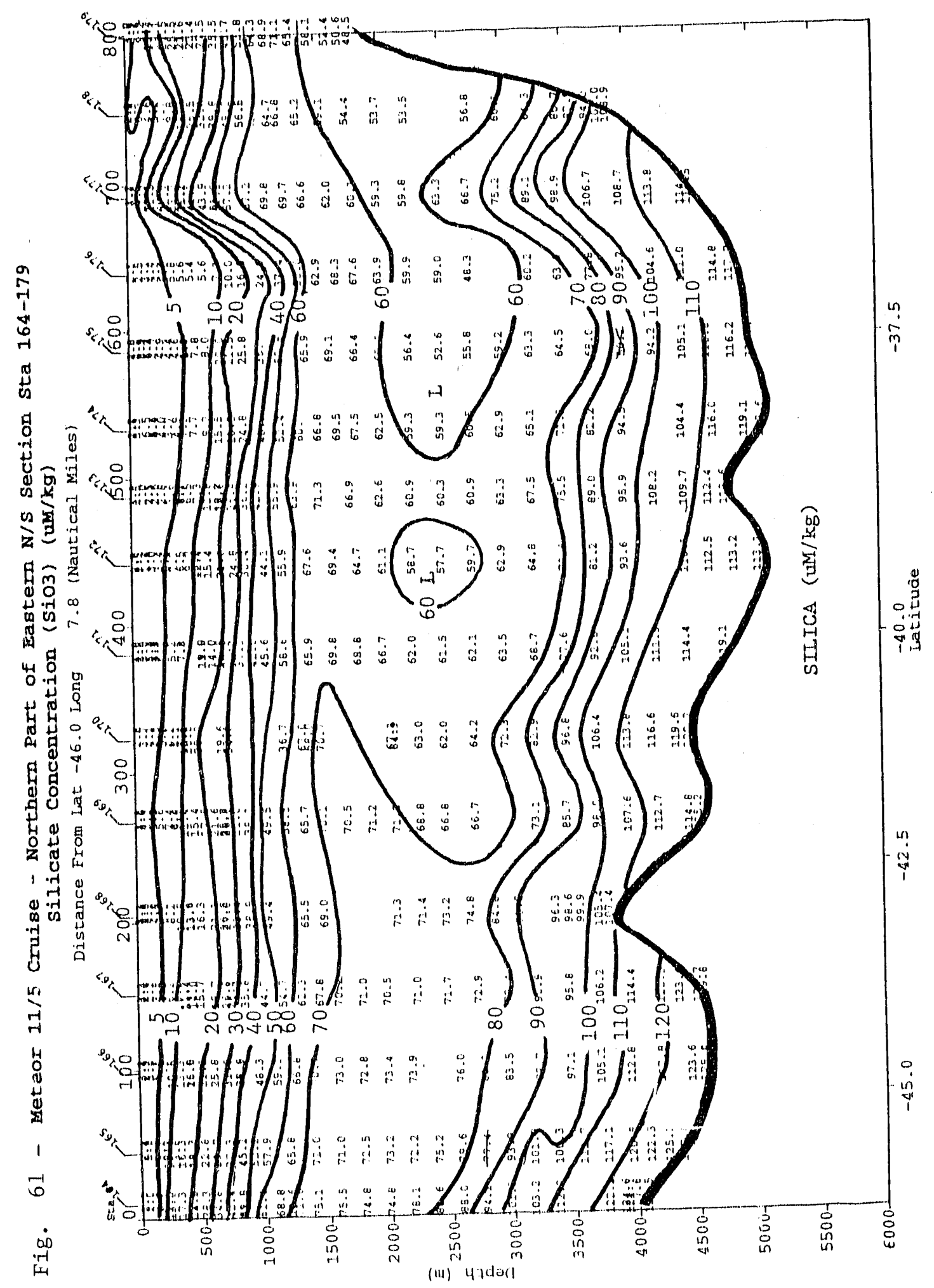




\section{PROPERTY -PROPER'TY RELATIONSHIPS}

The oceanographic data obtained during this expedition have been analyzed using property. property relationships in order to show processes controlling varlous biologically mediated quantities as well as their relationships with water masses and other oceanographic features such as the polar front and meridional temperature distribution.

Fig. 62 shows the potential temperature-salinity relationships observed during this expedition and includes all the data, which have been presented in parts in Figs. 10,20,31, 42 and 53. Among surface waters, the South Atlantic subtropical water is warmest and most saline $\left(23^{\circ} \mathrm{C}\right.$ and $\left.35.5 \mathrm{o} / \mathrm{00}\right)$, whereas the least saline water $(33,3 \%$ ) was observed close to the South American coast in the Drake Passage. 'The winter Antarctic surface water as cold as $-1.8^{\circ} \mathrm{C}$ has been identified as the near-surface sub-zero temperature minimum layer. This represents remnants of cold surface waters of the previous winter season. The densest water mass observed in this study is the Weddell Sea Bottom Water (WSBW), which is characterized by temperatures lower than about $-0.75^{\circ} \mathrm{C}$ indicating contributions from cold ice-shelf waters $\left(-1.9^{\circ} \mathrm{C}\right)$ of the southern Weddell Sea. The North Atlantic Deep Water (NADW) which originated in the high latitude North Atlantic is clearly depicted by the salinity maximum at temperatures in the vicinity of $2^{\circ} \mathrm{C}$.

Fig. 63 shows the relationships between the partial pressure of $\mathrm{CO}_{2}$ (at $20^{\circ} \mathrm{C}$ ) and the total $\mathrm{CO}_{2}$ concentration. Natural logarithm of these quantities are used, so that the slope of trends indicate the Revelle factor $\left(\gamma=\left(\partial \ln \mathrm{pCO}_{2} / \partial \ln \mathrm{TCO}_{2}\right)\right)$. The mean trend observed for surface waters (indicated by open circles) of the subtropical and subantarctic regions shows a typical value of 8 for the Revelle factor. It increases to 10 for the thermocline water and to 17 for the surface and deep waters of the Antarctic origin. The observed increase in the Revelle factor with depth suggests that the concentration of $\mathrm{CO}_{2}$ increases with depth faster than the alkalinity. Increases in $\mathrm{CO}_{2}$ may be attributed to the oxidation of organic debris and/or mixing with waters with greater $\mathrm{CO}_{2}$ concentrations; and increases in alkalinity to the dissolution of $\mathrm{CaCO}_{3}$ and/or mixing with waters with higher alkalinity values.

Fig. 64 shows the relationships between the total $\mathrm{CO}_{2}$ concentration and potential temperature. The former is normalized to a salinity of $35.00 \%$. A linear trend is observed for the surface waters (indicated by open circles) of the subtropical, subantarctic and antarctic regions: $\left(\mathrm{TCO}_{2}\right)_{\mathrm{s}=35}(\mathrm{uM} / \mathrm{kg})=$ $-11.5 \mathrm{~T}\left(\mathrm{C}^{\circ} \mathrm{C}\right)+2227$. Although the data points scatter more widely around this mean line in the Antarctic waters (south of the Polar Front $Z$ one), the mean deviat on for the waters warmer than about $3^{\circ} \mathrm{C}$ is about $10 \mathrm{uM} / \mathrm{kg}$. The highest total $\mathrm{CO}_{2}$ concentrations observed during this expedition arce associated with the 
Fig. 62 - potential temperature-salinity relationships observed during the F/S Meteor 11/5 Expedition In the South At Lantlo Ocean and northern Widdel.1. Sea, January-March, 1990. NADW $=$ North Ailantic Deep Water; $\mathrm{AABW}=$ AntarctLc Bottom Water; WSBW = Wedde1.1 Sea Bottom Water.

\section{F/S Meteor Cruise 11/5}

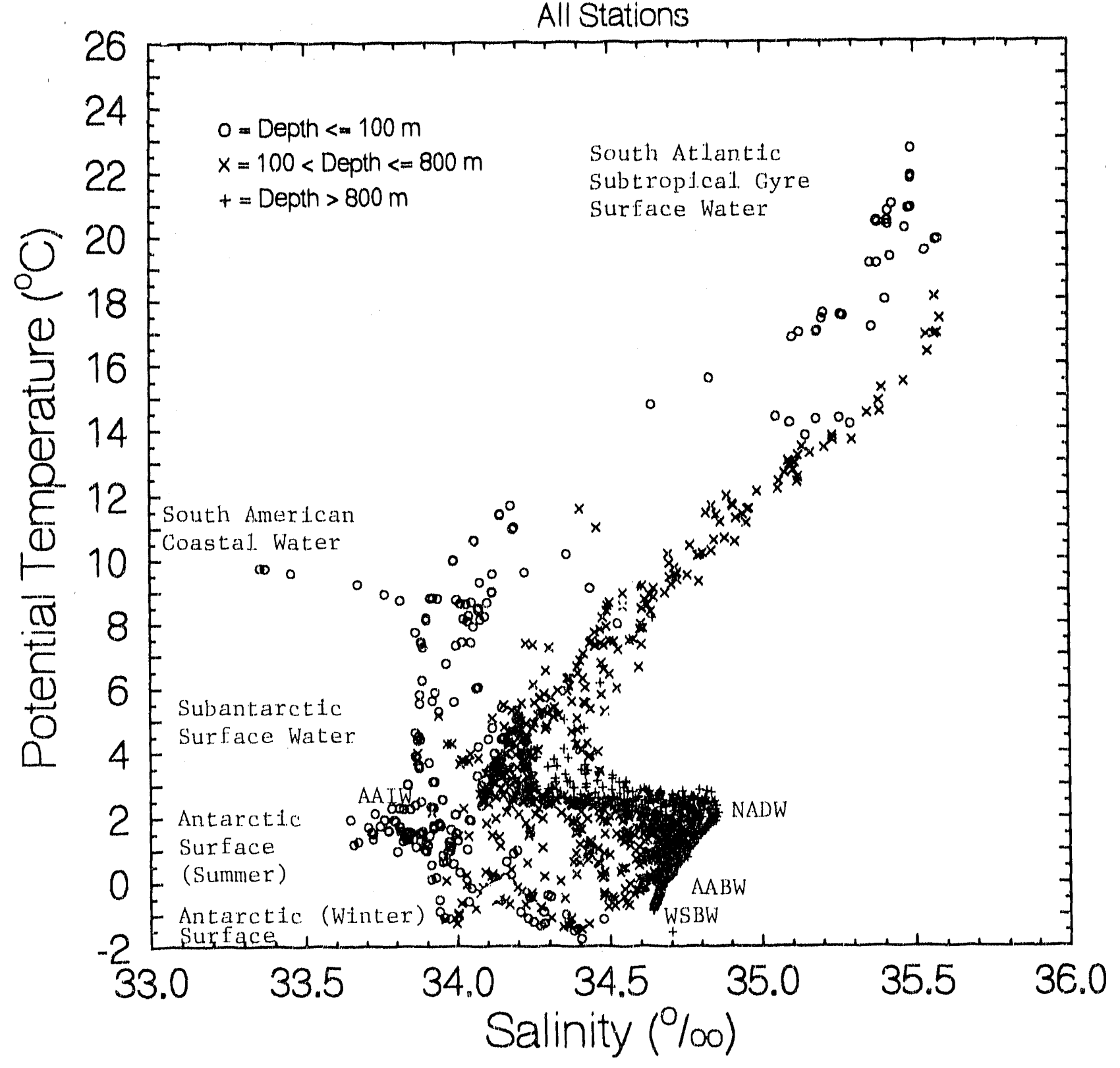


Fig, 63 - Relattonshtpbs between $\mathrm{pCO}_{2}$ at $20^{\circ} \mathrm{C}$ and the total. $\mathrm{CO}_{2}$ concentration (normalized to a salitulty of $35.00 \mathrm{o} / 00$ ) observed durfing the $\mathrm{F} / \mathrm{s}$ Meteor Lxped $\mathrm{L}$ tion In the South At lantec and northern Wedde1.1 Sea. Natural logartthm of the quantities $1 \mathrm{~s}$ plotted, so that the slopes of the regression lines findicate the Revelle Factor.

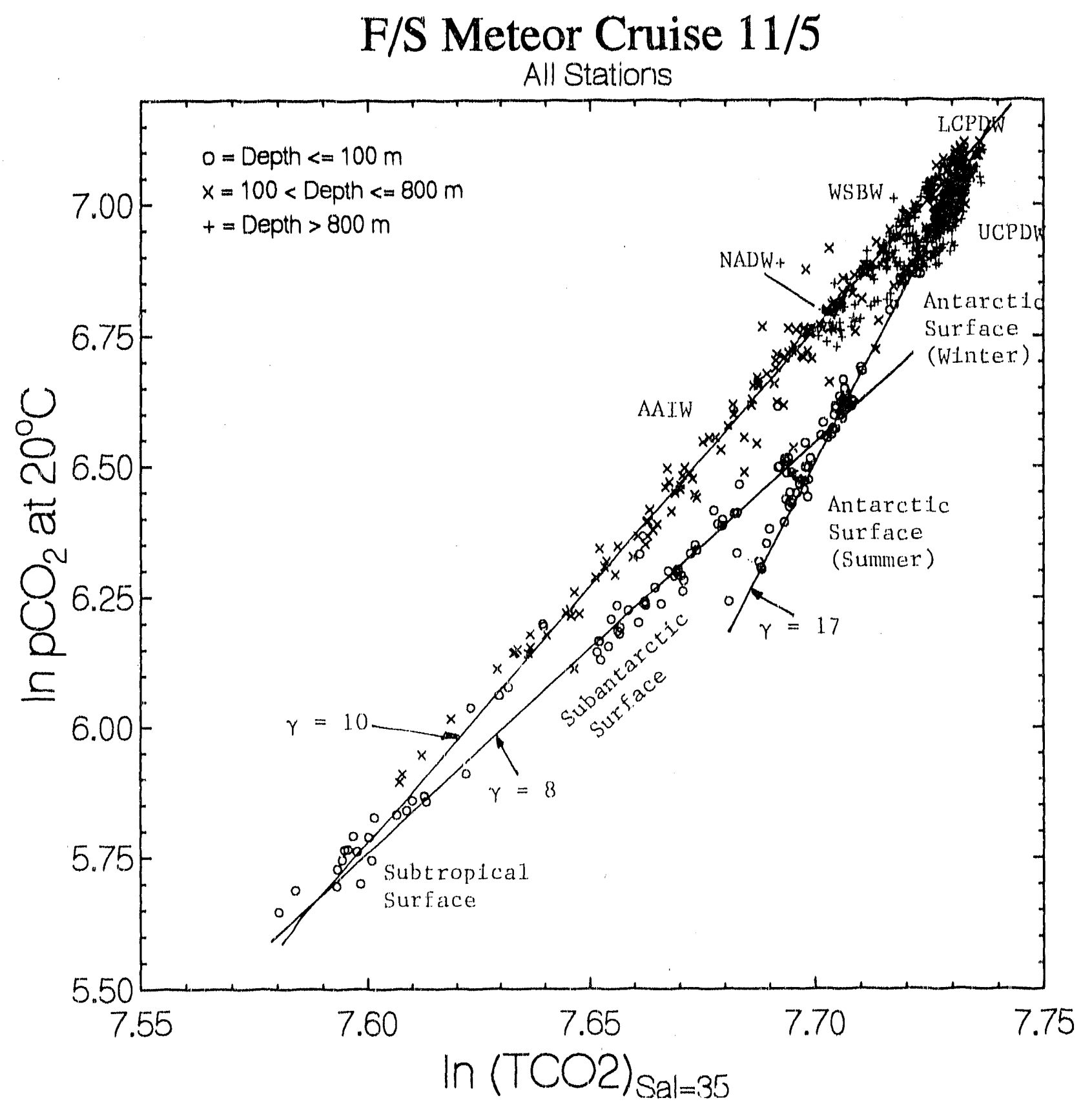


Fig. 64 - l'otal $\mathrm{CO}_{2}$-potential temperature relationshipa observed durting the $1 / \mathrm{s}$ Meteor Lxpedition, Jan.-March, 1990, tn the South Attantic Ocean and northern Weddel1. Sea. LCPDW and JCPDW $=$ Lower and Upper Clrcumpolar Deep Water; SPLOW = Southeast Paclific Low Oxygen Water; WSBW = Weddell. Sea Bottom Water; NADW = North Atlantic Deep Water; AASW (WInter) and AASW (Summer) = WInter and Summer Antarctic Surface Waters.

F/S Meteor Cruise 11/5

All Stations

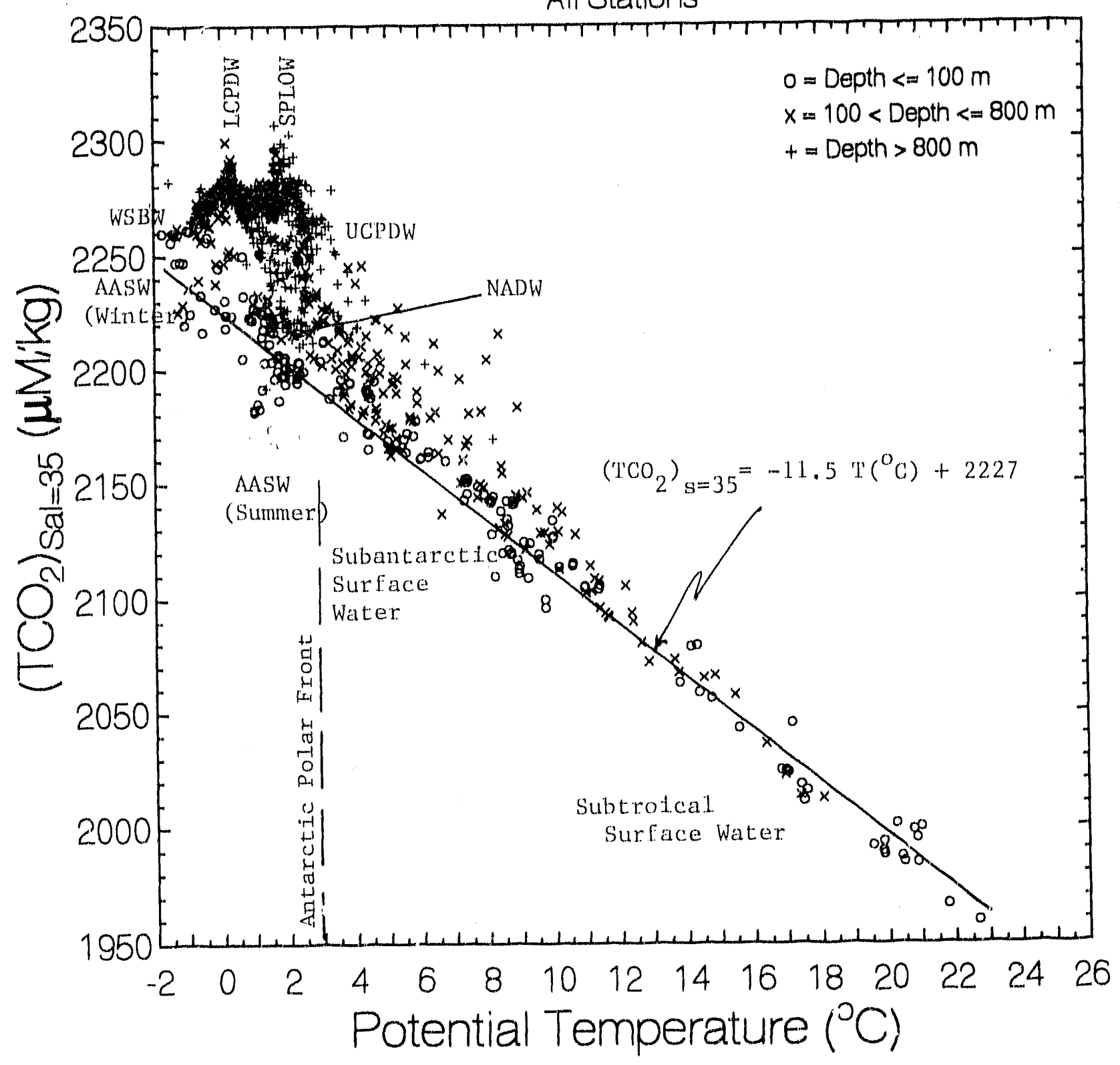


Lower Circumpolar Deep Water (1,CPDW) and Southeast Pactfic Low Oxygen Water. 'The former is found in the Northern Weddell Sea and South Alluntic ('lable 3) and the latter is found in the Drake Pas. suge ('Tuble 1),

Fig. 65 shows the relationships between the concentrations of oxygen und total $\mathrm{CO}_{2}$ dissolved in seawater. Warmor surfice waters have lower oxyged and $\mathrm{CO}_{2}$ concentrations, whereas colder surface waters have greater oxygen and $\mathrm{CO}_{2}$ concentrattons. This may be attributed mainly to the effect of temperature on gas srlubilities. The Antarctic winter surface water, which is represented by the sub-zero temperature minimum layer near the surfice, tends to have the oxygen and $\mathrm{CO}_{2}$ values closer to the deep water values. 'This may be due either to the oxtdation of organic debrts occurred since the prewtany winter, or to the mixing with deep water caused by deep winter convection.

The Southeast Pacific Low Oxygen Water (SPLOW, Table 1), which was presumably originated in the high productivity areas along the Chilean coust, has the highest total $\mathrm{CO}_{2}$ and lowest oxygen values. Among the Antarctic waters, the Weddell Sea Bottom Water (WSBW) has the highest oxygen concentration indicating contributions of young waters from kce-shelf.

Fig, 66 shows the rolationships between the concentration of nitrate and total $\mathrm{CO} 2$ in seawater. The subtropical and subantarctic surface waters exhibit two separate trends due mainly to large salinity differences. These two trends, however, collapse into one when the total $\mathrm{CO}_{2}$ concentrations nomalized to $35.00 \mathrm{o} / \mathrm{oO}$ salinity are used. Such a relationship is illustrated in Fig. 67 with the phosphate total CO. data.

The Upper Circumpolar Deep Water (UCPDW) has the highest nitrate concentration, and the Southeast Pacific Low Oxygen Water (SPLOW) has the highest total $\mathrm{CO}_{2}$ concentration observed during this study. The North Atlantic Deep Water (NADW) shows as a nitrate minimum in the vicinity of 2220 $\mathrm{uM} / \mathrm{kg}$ in the tolal $\mathrm{CO}_{2}$ concentration.

Fig. 67 shows the relationships between the phosphate concentration and the total $\mathrm{CO}_{2}$ concentration normalized to a salinity of $35.000 / 00$. The surface water values exhibit three trends: the subtropical trend for temperatures warmer than about $12^{\circ} \mathrm{C}$ has a $\triangle \mathrm{CO} 2 / \Delta \mathrm{P}$ ratio of 150 , the subantarctic water has the ratio of 93 and the Antarctic (mostly summer surfuce waters in the Weddell Sea) the ratio of 63 . The $\Delta \mathrm{CO}_{2} / \Delta \mathrm{P}$ ratio is influenced by the lateral and vertical water mixing, biological assemblage and air-sea $\mathrm{CO}_{2}$ flux. However, presently the regional differences observed in the ratio can not be quantitatively accounted for. 
Fig. 65 - Relationshlps between the concentrations of oxygen and total. $\mathrm{CO}_{2}$ observad durlug the $\mathrm{F} / \mathrm{S}$ Meteor Rxpedttiton, Jan.-March, 1990, Lin the South Ntiantic Ocean and northern Wedde1.l. Sea. WSBW a Weddell. Sea Bottom Water; $\triangle A B W=$ Antarctic Bottom Water; WSDW $\Rightarrow$ Weddell Sea Deep Water; LCPDW and UCPDW ta Lower and Upper Citrcumpolar Deep Water; SPLOW = Southeast PaciftL Low Uxygen Water; NADW $=$ North Atlantide Deep Water; $\Lambda \Lambda \mathrm{T}=$ Antarctic Intermedimate Water.

\section{F/S Meteor Cruise 11/5}

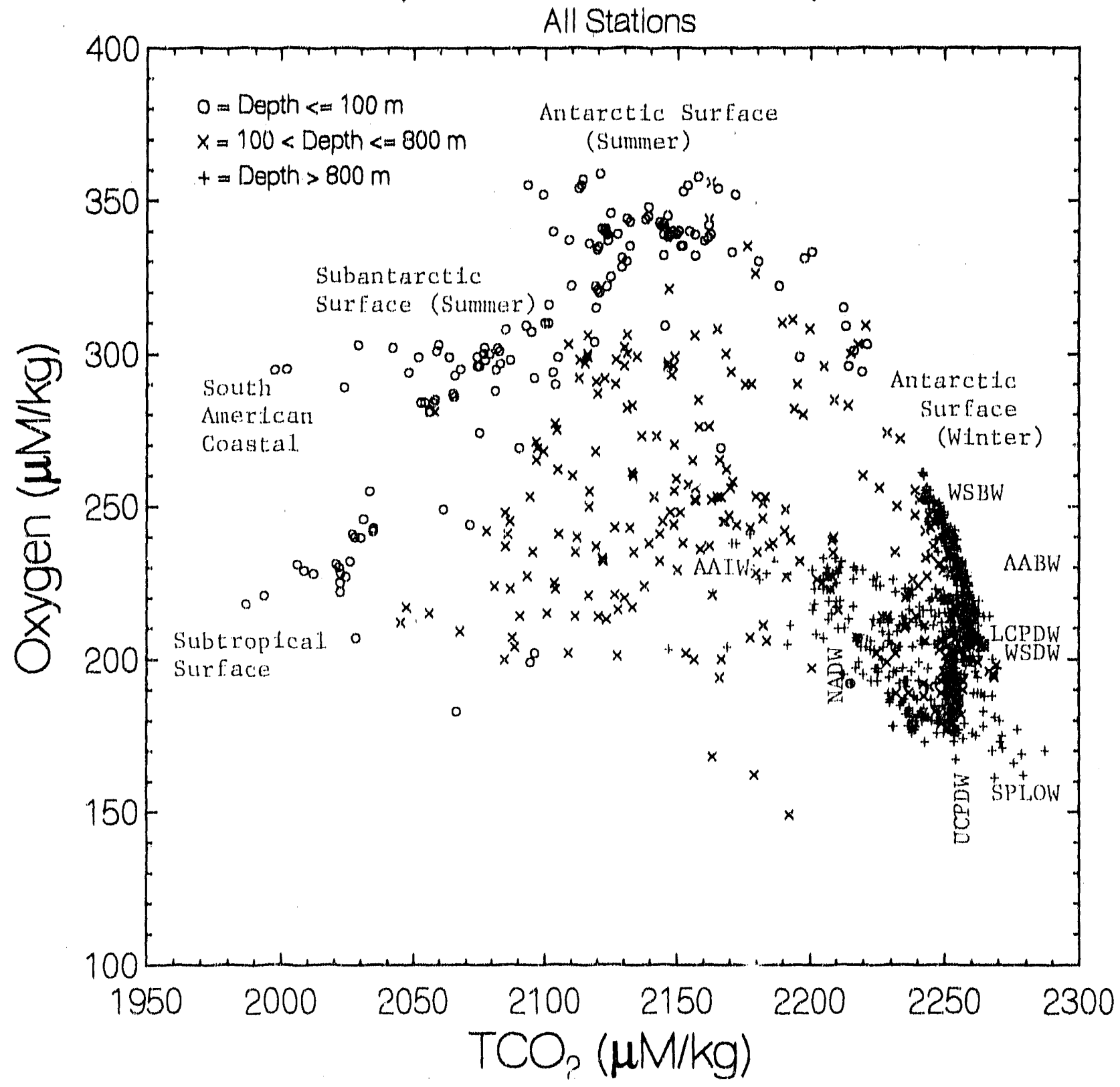


Flg. 66 - Relat Lonships between the concentrations of nftrate and total $\mathrm{CO}_{2}$ observed durding the Fi/s Meteor lixpeditthon, Jan,-March, 1990, fin the South Atiantice Gean and northern Weddolit Sea. UClibW and LCllow ap uper and Lower CArcumpolar Deep Water; SPLOW a Southeast Pactifte Low Oxygen Water; $\Lambda \Lambda B W=$ Antarctic Bottom Water; WSBW a Weddelil. Sea Bottom Water; NADW a North $\Lambda$ tilantic Deep Water; $\Lambda \Lambda T W=$ Antarctic Intermeditate Water.

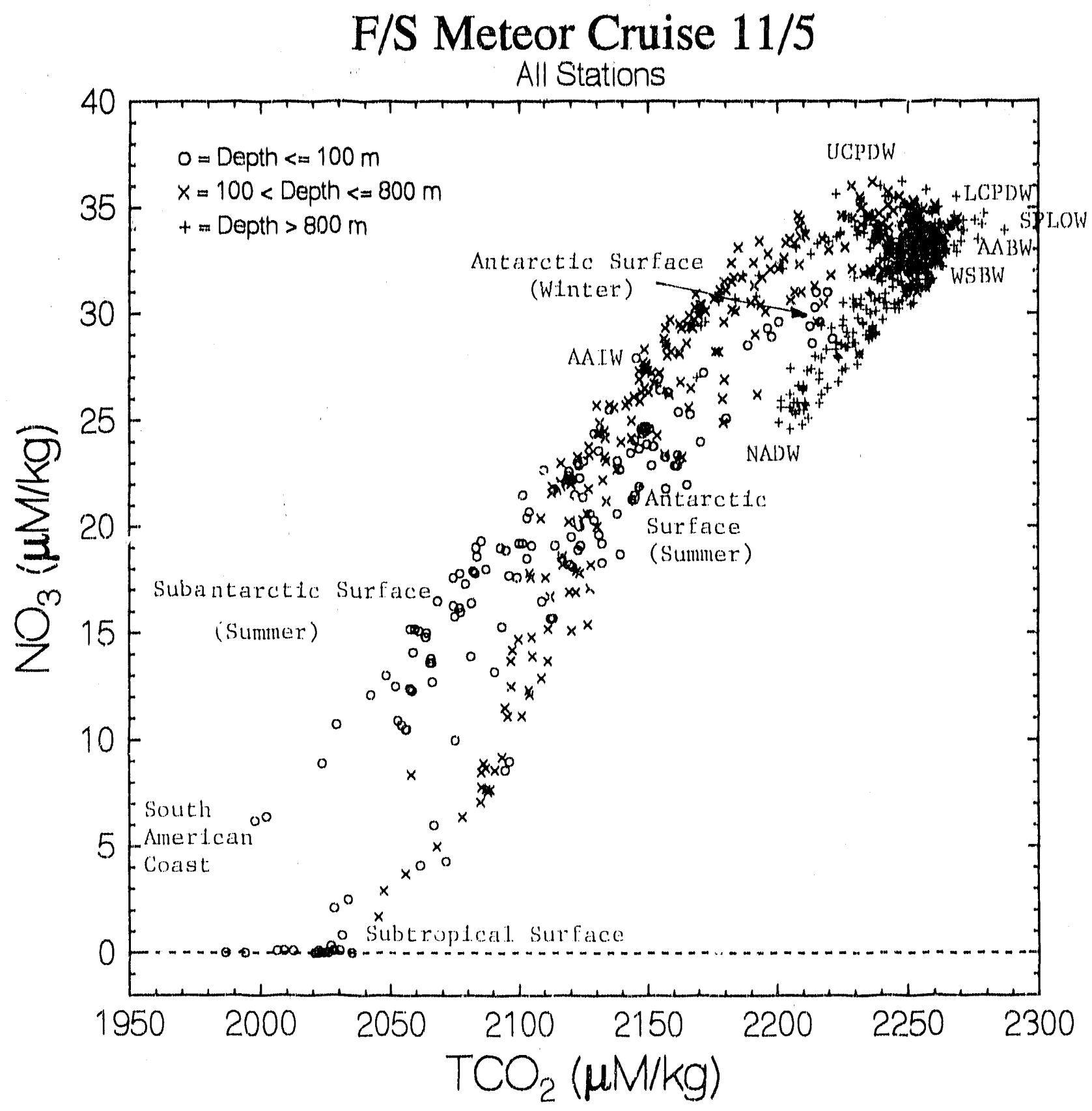


Fig. 67 -- Relationships botween the concentrations of phosphate and total $\mathrm{CO}_{2}$ normalized to a salinity of $35.00 \mathrm{o} / \mathrm{oo}$, observed during the F/S Meteor Expedition, Jan.-March, 1990, in the South Atlantic Ocean and northern Wedde1.1. Sea. UCPDW and LCPDW = Upper and Lower Circumpolar Deep Water; SPLOW = Southeast Pacific Low Oxygen Water; WSBW = Wedde11 Sea Bottom Water; $\mathrm{AABW}=$ Antarctic Bottom Water; AAIW = Antarctic Intermediate Water; NADW $=$ North Atlantic Deep Water.

\section{F/S Meteor Cruise 11/5}

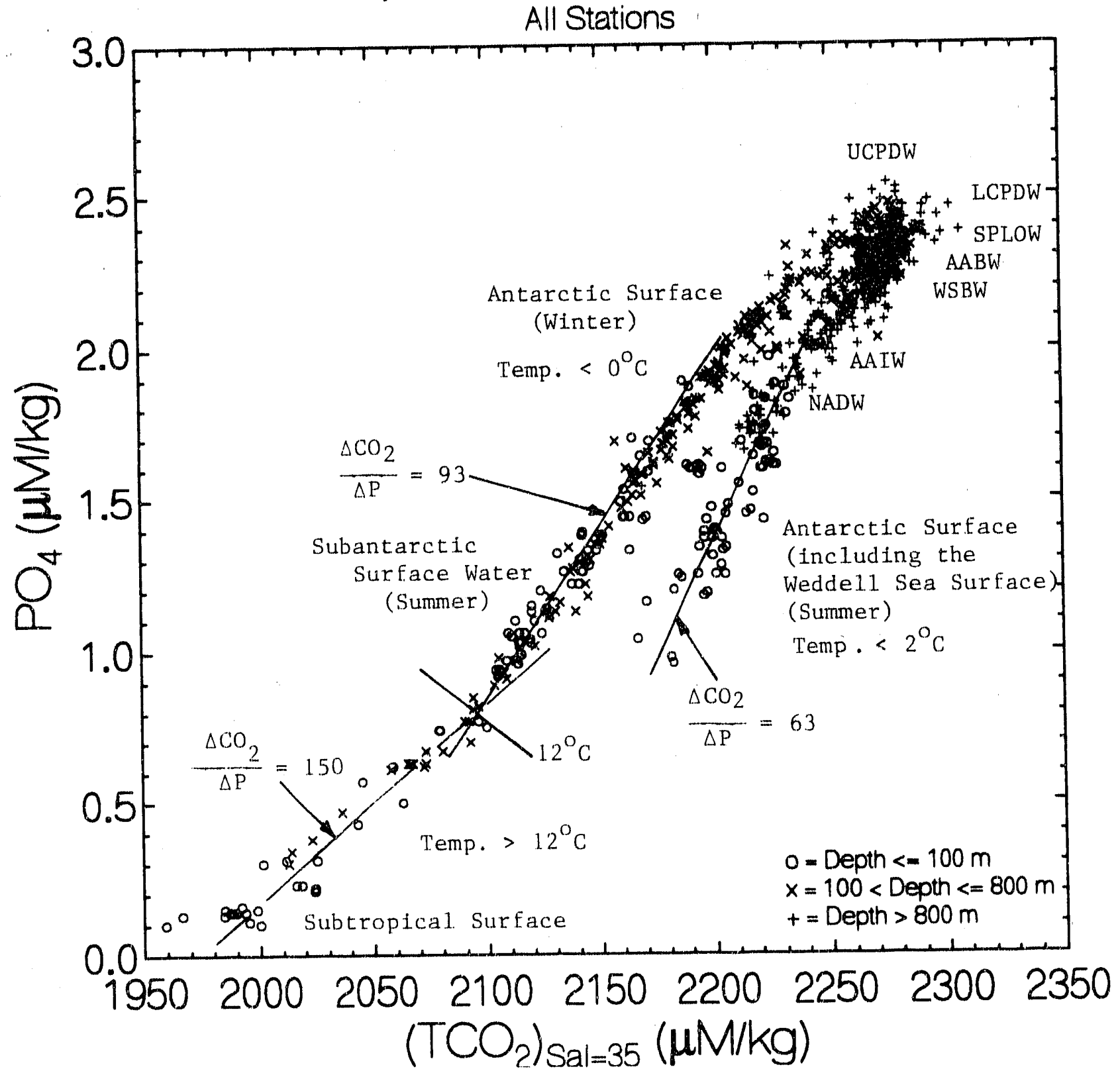


Fig. 68 shows the relationships between the natural logarithm of $\mathrm{pCO}_{2}$ at $20^{\circ} \mathrm{C}$ and the concentration of phosphate. The data for surface waters in the antarctic (winter and summer), subautarctic and subtropical regions exhibits a linear trend: $\ln \left(\mathrm{pCO}_{2}\right.$ at $\left.20^{\circ} \mathrm{C}\right)=0.52\left(\mathrm{PO}_{4}\right)+5.70$. As shown in Fig. 67, there are three distinctly different trends observed for the total $\mathrm{CO}_{2}$-phosphate concentrations in surface water. In addition, a linear relationship is observed for the logarithmic plot for $\mathrm{pCO}_{2}$ and total $\mathrm{CO}_{2}$ concentration (Fig. 63) in surface waters. Therefore, in order to have a linear trend for $\ln \mathrm{PCO}_{2}$ and phosphate, the alkalinity of surface water must change regionally in such a way to offset changes in the total $\mathrm{CO}_{2}$-phosphate trends.

Fig. 69 shows the relationships between the potential alkalinity and total $\mathrm{CO}_{2}$ concentration. Both of these quantities are normalized to a salinity of $35.00 \mathrm{o} / 00$. The potential alkalinity is defined as [(Total Alkalinity) + (Nitrate)] (Brewer and Goldman, 1976). It is changed by dissolution and precipitation of $\mathrm{CaCO}_{3}$, but remains constant for the photosynthetic utilization of $\mathrm{CO}_{2}$ and nutrient salts or the oxidation of biological debris. The surface water data (see open circles) exhibits a linear trend with a slope of 0.423 . The observed trend may be interpreted as floows; the surface water formed by the winter upwelling of deep waters loses $\mathrm{CO}_{2}$ and potential alkalinity by photosynthesis and biogenic production of $\mathrm{CaCO}_{3}$ shells as it is transported northward and incorporated eventually into the subtrofical gyre water. If the air-sea $\mathrm{CO}_{2}$ flux is neglected (normally less than $10 \%$ of the biological $\mathrm{CO}_{2}$ utilization), the slope of the surface water trend gives a (organic carbon fixation) $/\left(\mathrm{CaCO}_{3}\right.$ production) ratio of about 4 or $80 \%$ of carbon removal by organic carbon formation and $20 \%$ by calcareous shell production.

The highest potential alkalinity values were observed in the near bottom water in the Cape Basin, north of the Atlantic-Indian Ridge. The Cape Basin Bottom Water (CBBW) has a potential temperature and salinity of about $0.6^{\circ} \mathrm{C}$ and $34.73 \mathrm{o} / 00$, and hence is warmer and more saline than the Antarctic Bottom Water (AABW) and the Weddell Sea Bottom Water (WSBW). However, it contains as much oxygen as the $\mathrm{AABW}$, but distinctly less silica. Its total $\mathrm{CO}_{2}, \mathrm{pCO}_{2}$, oxygen, nitrate, phosphate and silica concentrations are similar to those for the WSBW. Accordingly, it appears to represent a portion of WSBW, which entered into the Cape Basin through a fracture across the Atlantic-Indian Ridge system and received additional alkalinity by the dissolution of $\mathrm{CaCO}_{3}$ sediments on the Cape Basin floor. Since the GEOSECS alkalinity data for the Indian Ocean do not show the presence of high alkalinity abyssal waters, the high alkalinity values in the CBBW do not appear to be derived from the Indian Ocean.

Fig. 70 shows the relationships between the concentrations of nitrate and phosphate. A linear regression of the entire data set yields a mean slope of $15.47( \pm 0,04)$ with a root mean square deviation of $\pm 0.9 \mathrm{uM} / \mathrm{kg} \mathrm{NO}$. This slope is consistent with the Redfield N/P ratio of 16. 
Fig. 68 - Relationships between $\mathrm{pCO}_{2}$ at $20^{\circ} \mathrm{C}$ and the concentration of phosphate observed during the F/S Meteor Expedition, Jan.-March, 1990, in the South Atlantic Ocean and the northern Weddeil Sea. UCPDW and LCPDW = Upper and Lower Circumpolar Deep Water; $\mathrm{AABW}=$ Antarctic Bottom Water; WSBW = Weddel1 Sea Bottom Water; NADW = North Atlantic Deep Water; AAIW = Antarctic Intermediate Water.

\section{F/S Meteor Cruise 11/5}

All Stations

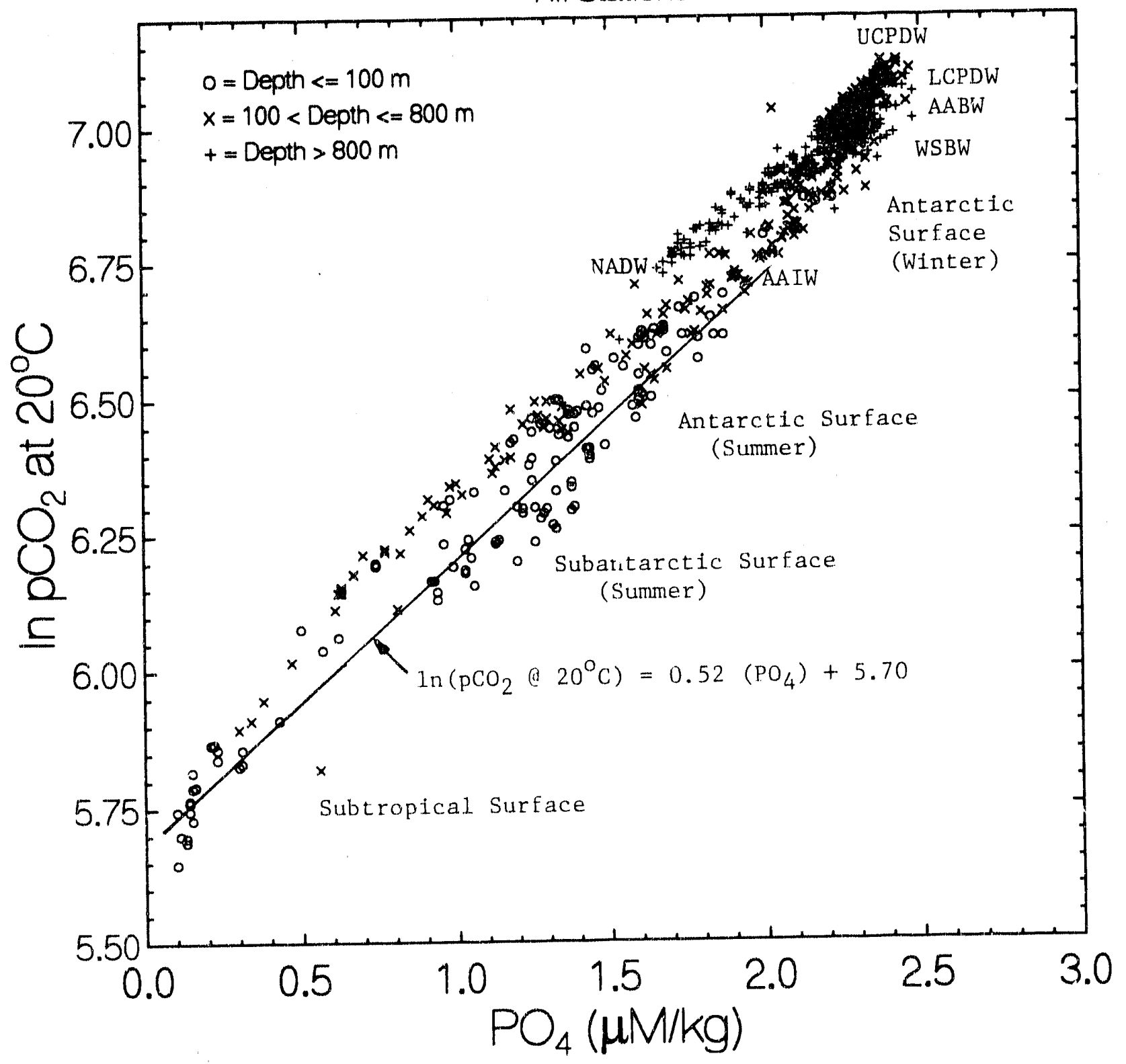


Fig. ig - Relationships between the potential alkalinity and the tota1 $\mathrm{CO}_{2}$ concentration observed in the South Altantic Ocean and the northern Wedde11. Sea. Both quantities are normalized to a salinity of 35.00 o/oo. $\quad$ CBBW $=$ Cabe Basin Bottom Water; LCPDW and UCPDW = Lower and Upper Circumpolar Deep Water; WSDW = Weddell Sea Deep Water; WSBW = Weddell Sea Bottom Water; NADW = North Atlantic Deep Water;

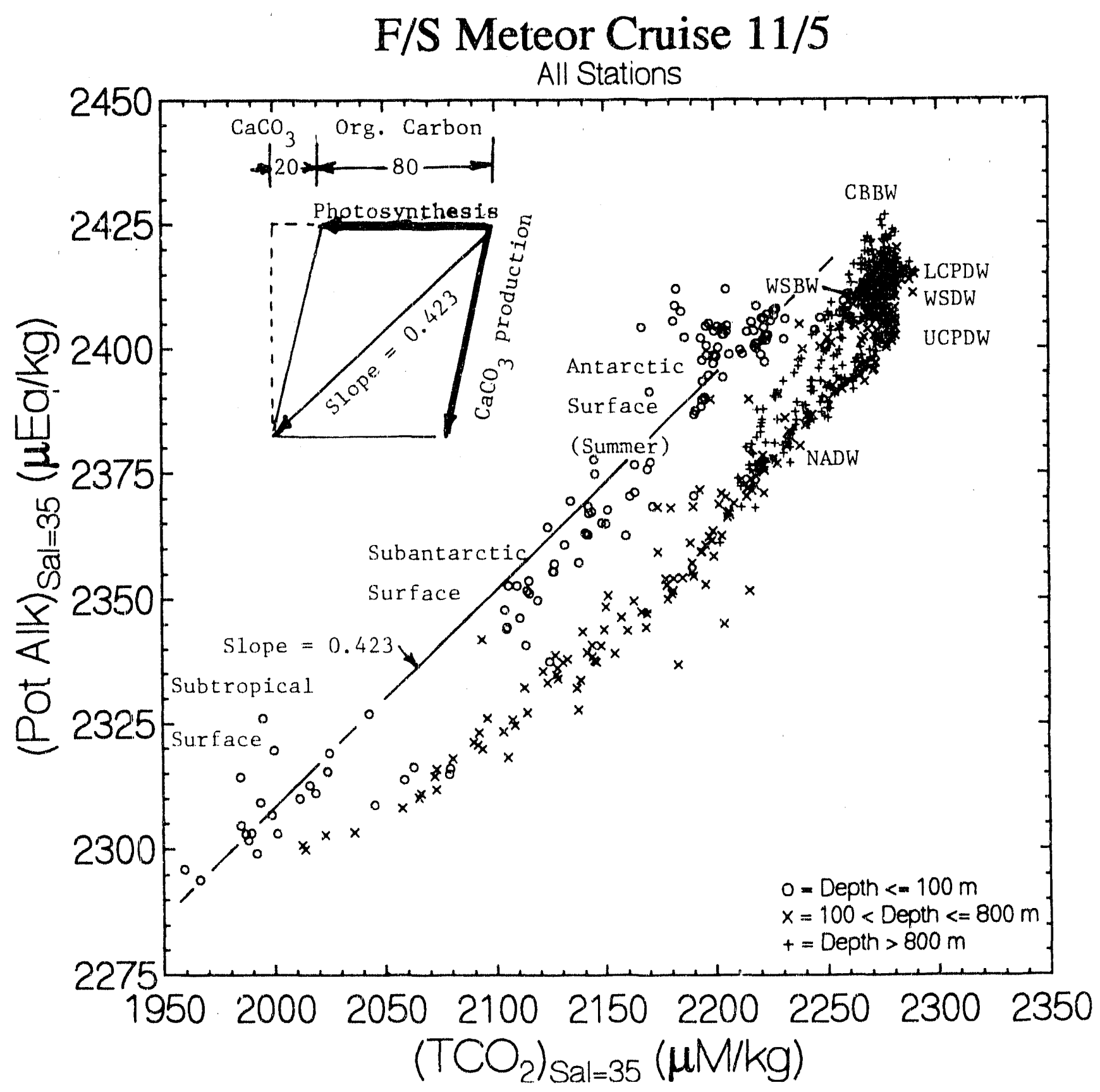


Fig. $\quad 70$ - Relationships between the concentrations of nitrate and phosphate in seawater observed during the $\mathrm{F} / \mathrm{S}$ Meteor Expedition, Jan.-March, 1990, in the South Atlantic Ocean and northern Weddell Sea. A linear least-squares fit to the data yields a mean Redfield $\mathrm{N} / \mathrm{P}$ ratio of 15.5 .

\section{F/S Meteor Cruise 11/5}

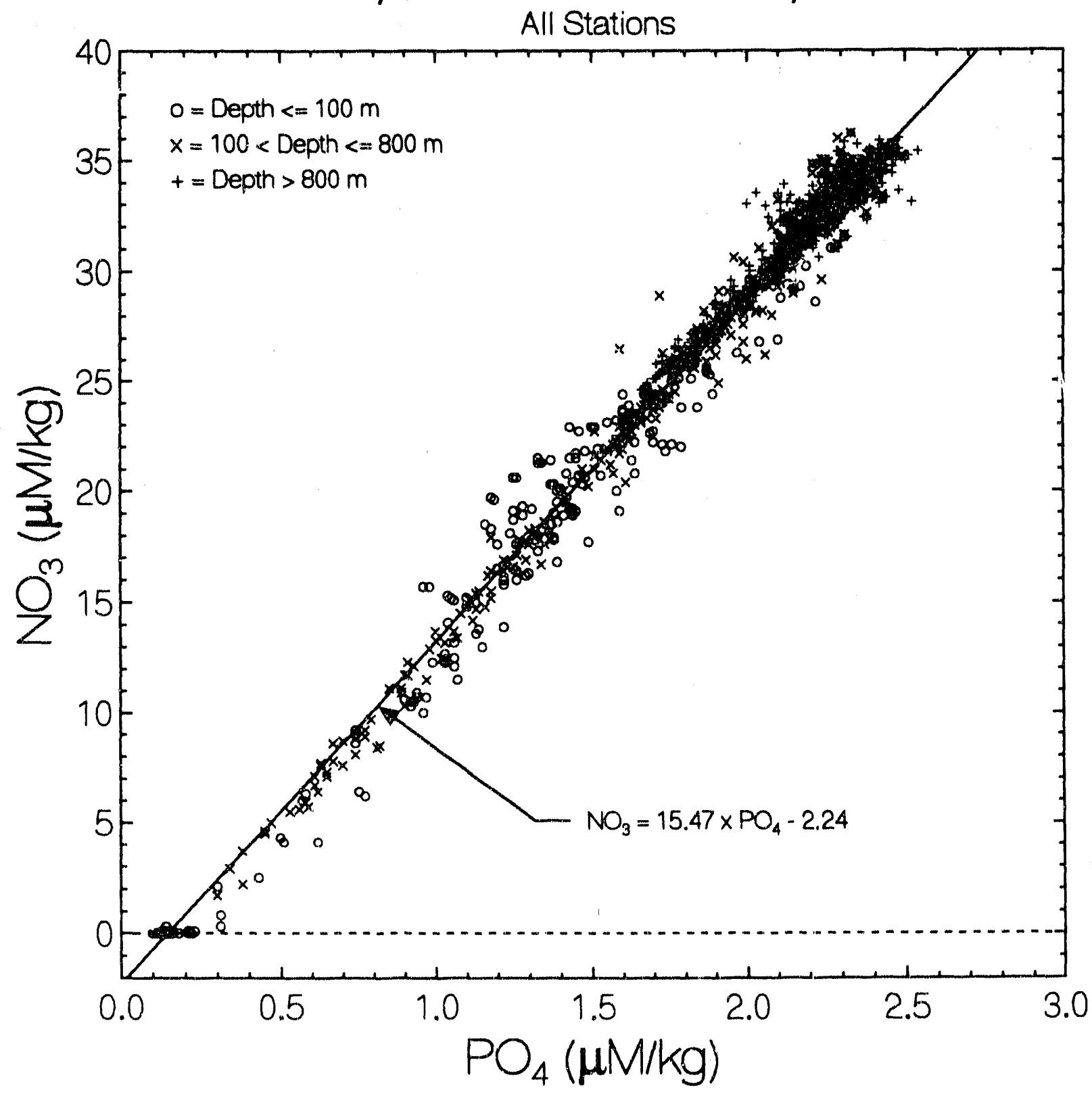


Figs. 71 and 72 show respectively the changes in the nitrate and phosphate concentrations with potential tempe:ature. The surface water values (open circles) for the both quantities appear to decline linearly northward in the subantarctic regime (between the Antarctic polar front and the northern edge of the subtropical convergence) to near-zero values in waters warmer than ąhout $18^{\circ} \mathrm{C}$. On the other hand, in the areas south of the Antarctic front (less than $2^{\circ} \mathrm{C}$ ), another trend is observed indicating a different biological regime in the Weddell and Antarctic waters.

The Upper Circumpolar Deep Water (UCPDW) has the highest nitrate and phosphate values observed during the expedition. The North Atlantic Deep Water (NADW) is clearly depicted by a minimum in nitrate and phosphate in the vicinity of $2^{\circ} \mathrm{C}$.

Fig. 73 shows the relationships between the silica concentration and potential temperature. Unlike the concentrations of nitrate and phosphate shown in Figs. 71 and 72 , the silica concentration in surface water is reduced to near-zero values north of the Antarctic polar front and remains low through the subantarctic and subtropical regions.

The highest silica concentrations are found in the Southeast Pacific Bottom Water (SPBW), which is present in the Drake Passage section. The Weddell Sea Deep Water (WSDW) has the second highest silica concentration exhibiting a maximum at about $-0.5^{\circ} \mathrm{C}$ whereas the Weddell Sea Bottom Water (WSBW) is shown with a sharp silica minimum in the vicinity of $-1.00^{\circ} \mathrm{C}$.

Fig. 74 shows the relationships between the silica concentration and salinity. In this plot, the relationships between various deep water masses are well resolved. The Southeast Pacific Bottom Water (SPBW) and the Weddell Sea Deep Water (WSDW) are depicted by two high peaks up to $143 \mathrm{uM} / \mathrm{kg}$ and $136 \mathrm{uM} / \mathrm{kg}$ respectively. In contrast, the North Atlantic Deep Water (NADW) exhibits a sharp minimum at a salinity of about 38.0 \%/oo. The Upper and Lower Circumpolar Deep Water (UCPDW and LCPDW), between which the NADW has been shown to intrude (see Figs. 41 through 48 ), are depicted as a kink point.

Fig. 75 shows the relationships between the nitrate and silica concentrations. The surface water data (open circles) indicate that the silica concentration is reduced to near-zero values while the waters still contain 15 to $20 \mathrm{uM} / \mathrm{kg}$ nitrate.

The Upper Circumpolar Deep Water (UCPDW) and Southeast Pacific Low Oxygen Water (SPLOW) exhibit the highest nitrate values, while the Southeast Pacific Deep and Bottom Waters (SPDW and SPBW) show the highest silica values. 
Fig. 71 - Relationships between the nitrate concentration and potential temperature observed during the F/S Meteor Expedition, Jan.-March, 1.990, in the South Atlantic Ocean and northern Weddell Sea. UCPDW and LCPDW = Upper and Lower Circumpolar Deep Water; WSDW $=$ Wedde11 Sea Deep Water; AABW = Antarctic Bottom Water; WSBW = Weddel1. Sea Bottom Water; NADW = North Atlantic Deep Water; $A A S W=$ Antarctic Surface Water.

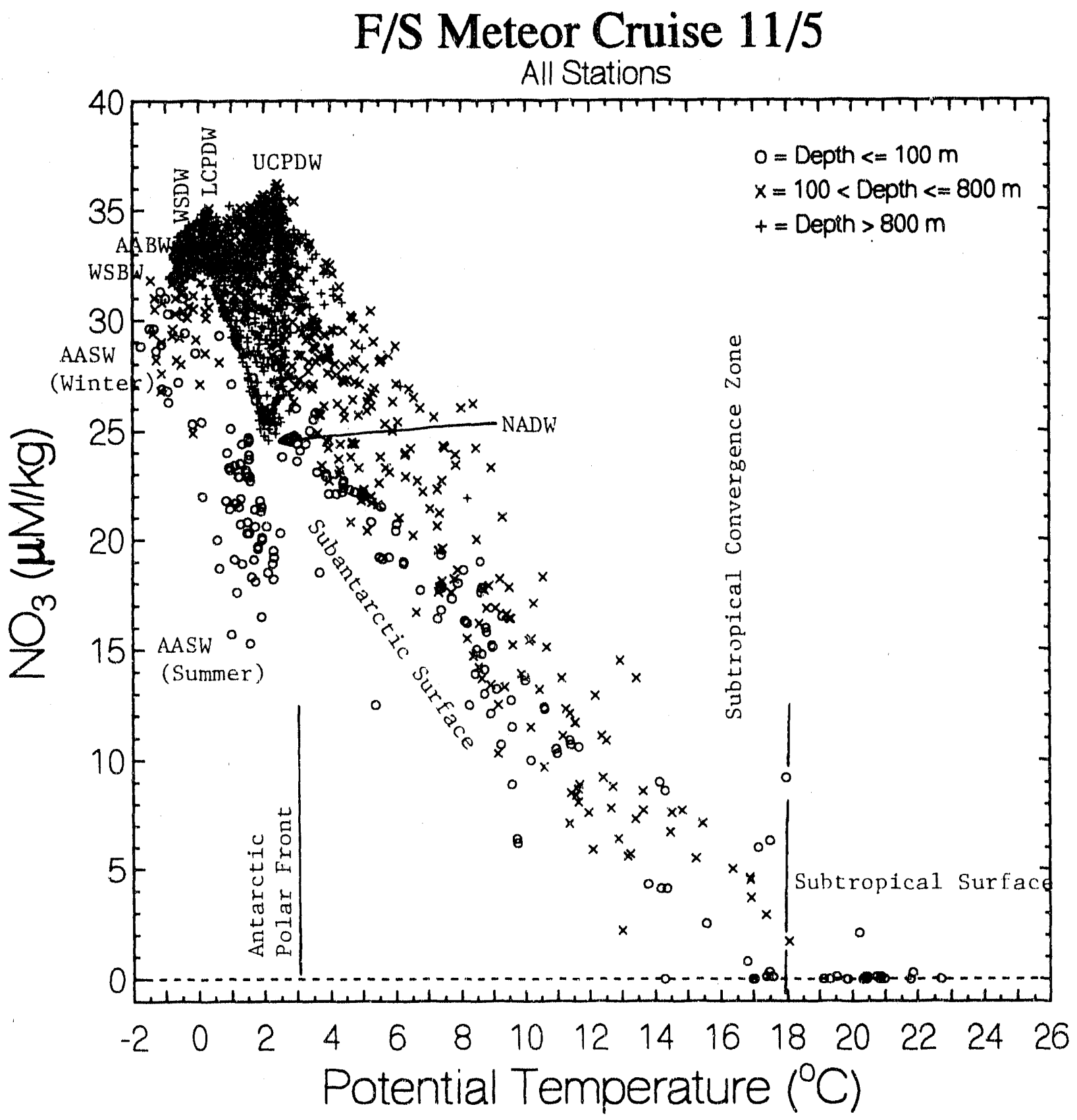


Fig. 72 - Relationships between the phosphate concentration and potential temperature observed during the $\mathrm{F} / \mathrm{S}$ Meteor Expedition, Jan.-March, 1990, in the South Atlantic Ocean and northern Wedde11 Sea. UCPDW and LCPDW = Upper and Lower Circumpolar Deep Water; $\mathrm{AABW}=$ Antarctic Bottorn Water; WSBW = Wedde11 Sea Bottom Water; NADW = North Atlantic Deep Water; AASW = Antarctic Surface Water.

\section{F/S Meteor Cruise 11/5}

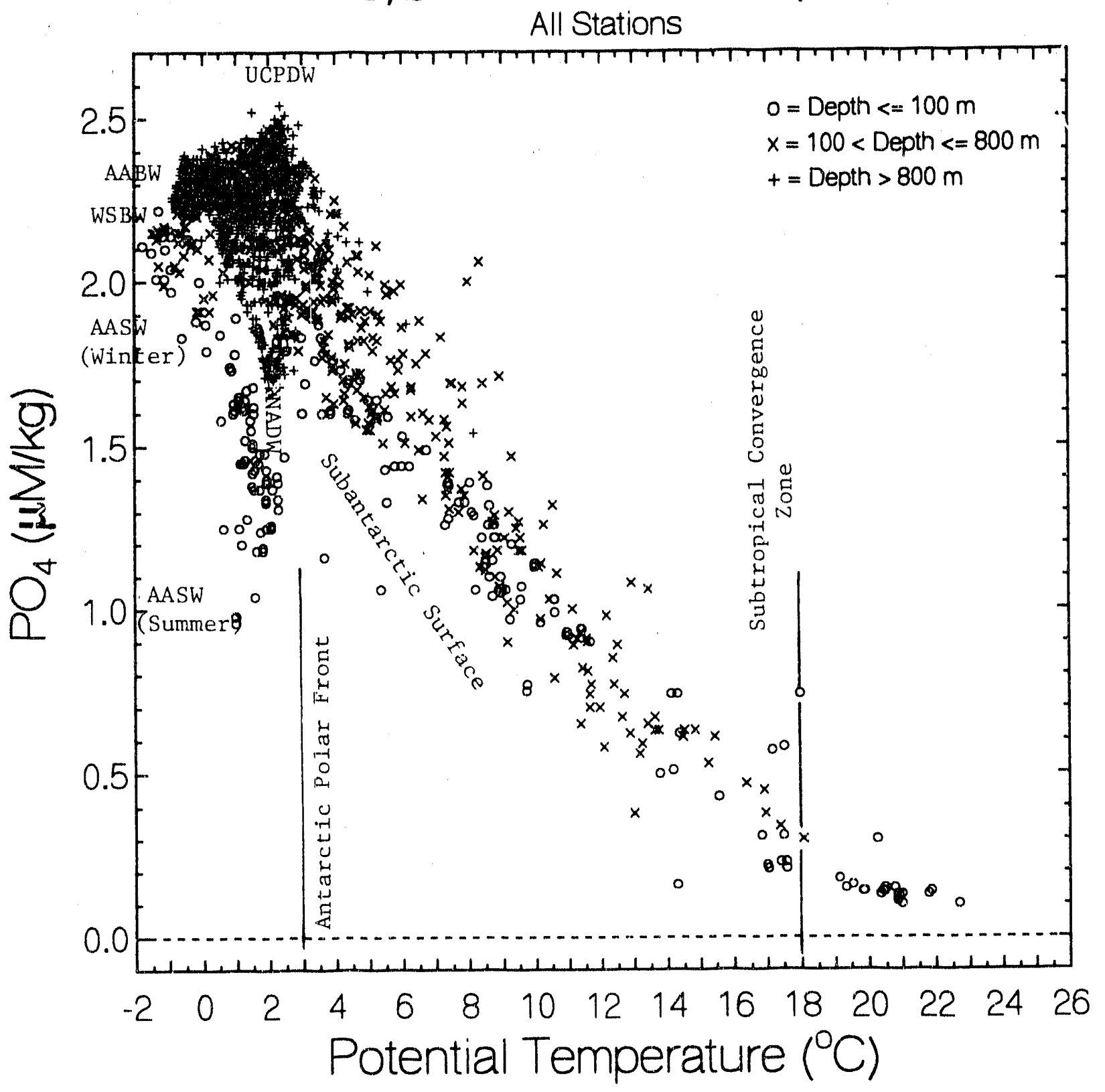


Fig. $\quad 73$ - Relationships between the concentration of silica and potential temperature observed during the $\mathrm{F} / \mathrm{S}$ Meteor Expedition, Jan.-March, 1990, in the South Atlantic Ocean and northern Weddell sea.

SPBW = Southeast Pacific Bottom Water; WSDW = Wedde11 Sea Deep Water; WSBW = Wedde11 Sea Bottom Water; $\mathrm{AABW}=$ Antarctic Bottom Water; NADW = North Atlantic Deep Water, AASW = Antarctic Surface Water; SbAASW = Subantarctic Surface Water.

\section{F/S Meteor Cruise 11/5}

\section{All Stations}

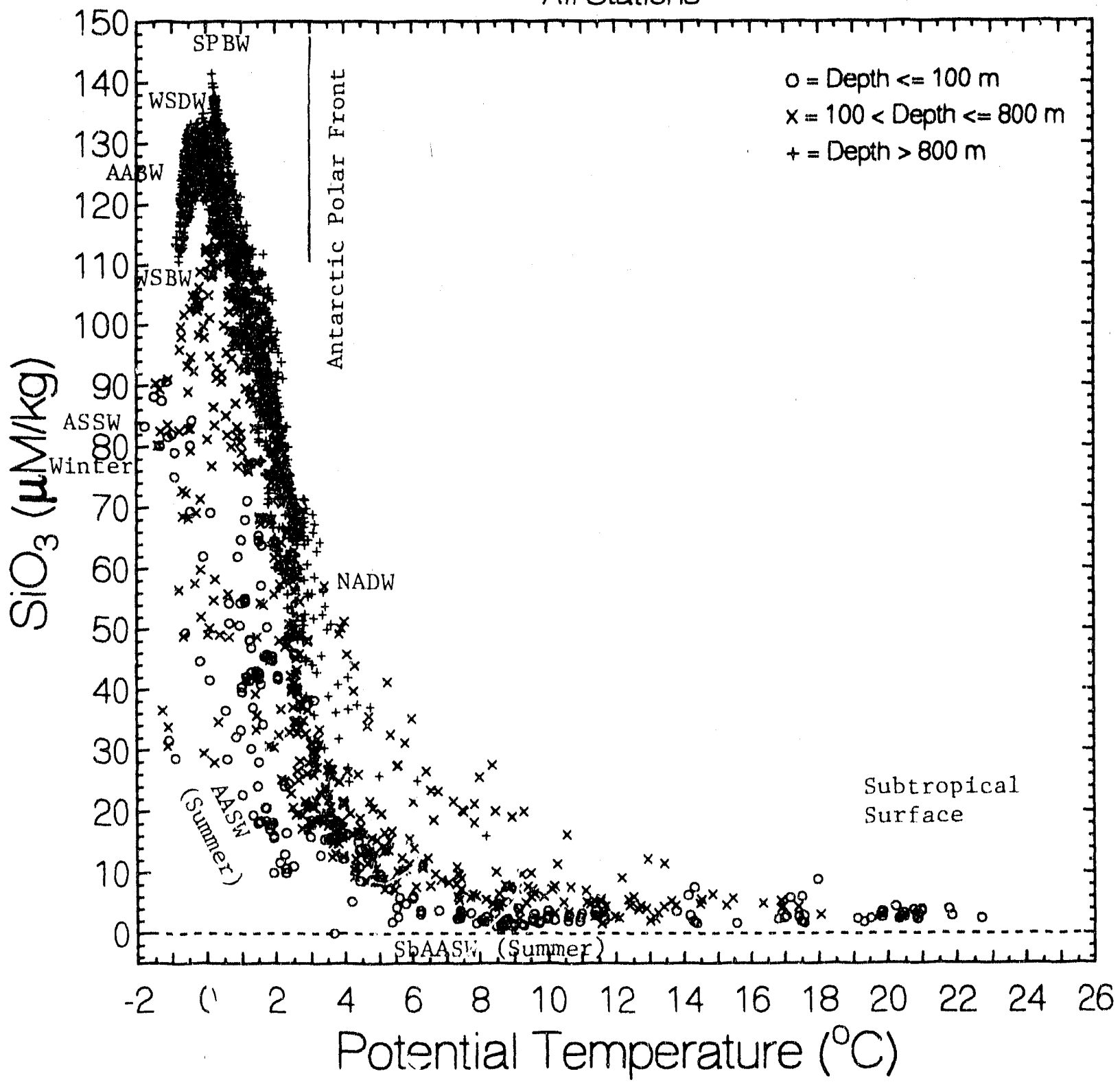


Fig, 74 - Relationships between the concentration of silica and salinity observed during the F/S Meteor Expeditfon, Jan.-March, 1990, in the South Atlantic Ocean and northern Weddell Sea. SPBW $=$ Southeast Pacific Bottom Water; WSDW = Weddell Sea Bottom Water; WSDW = Wedde11 Sea Deep Water; $\mathrm{AABW}=$ Antarctic Bottom Water; LCPDW = Lower Circumpolar Deep Water; $\mathrm{NADW}=$ North Atlantic Deep Water; AAIW = Antarctic Intermediate Water; UCPDW = Upper Circumpolar Deep Water.

F/S Meteor Cruise 11/5

All Stations

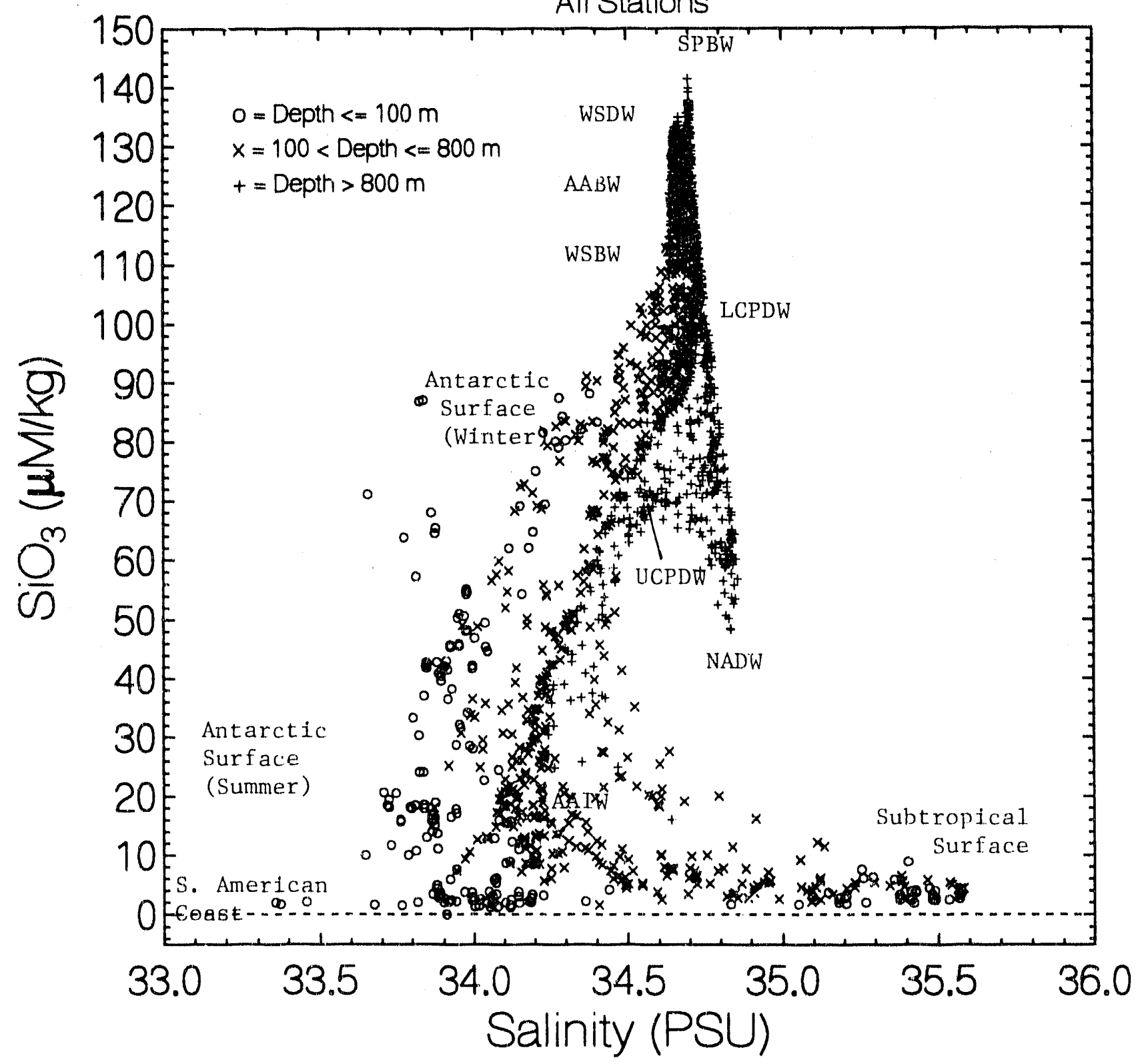


Fig. 75 - Nitrate and silicate relationships observed during the F/S Meteor 11/5 Expedition in the South Atlantic Ocean and northern Wedde11 Sea, January-March, 1990. UCPDW and LCPDW $=$ Upper and 1ower Circumpolar Deep Water; SPLOW = South Pacific Low Oxygen Water; SPDW $=$ Southeast Pacific Deep Water; $\mathrm{SPBW}=$ Southeast Pacific Bottom Water; NADW = North Atlantic Deep Water; AAIW = Antarctic Intermediate Water.

\section{F/S Meteor Cruise 11/5}

All Stations

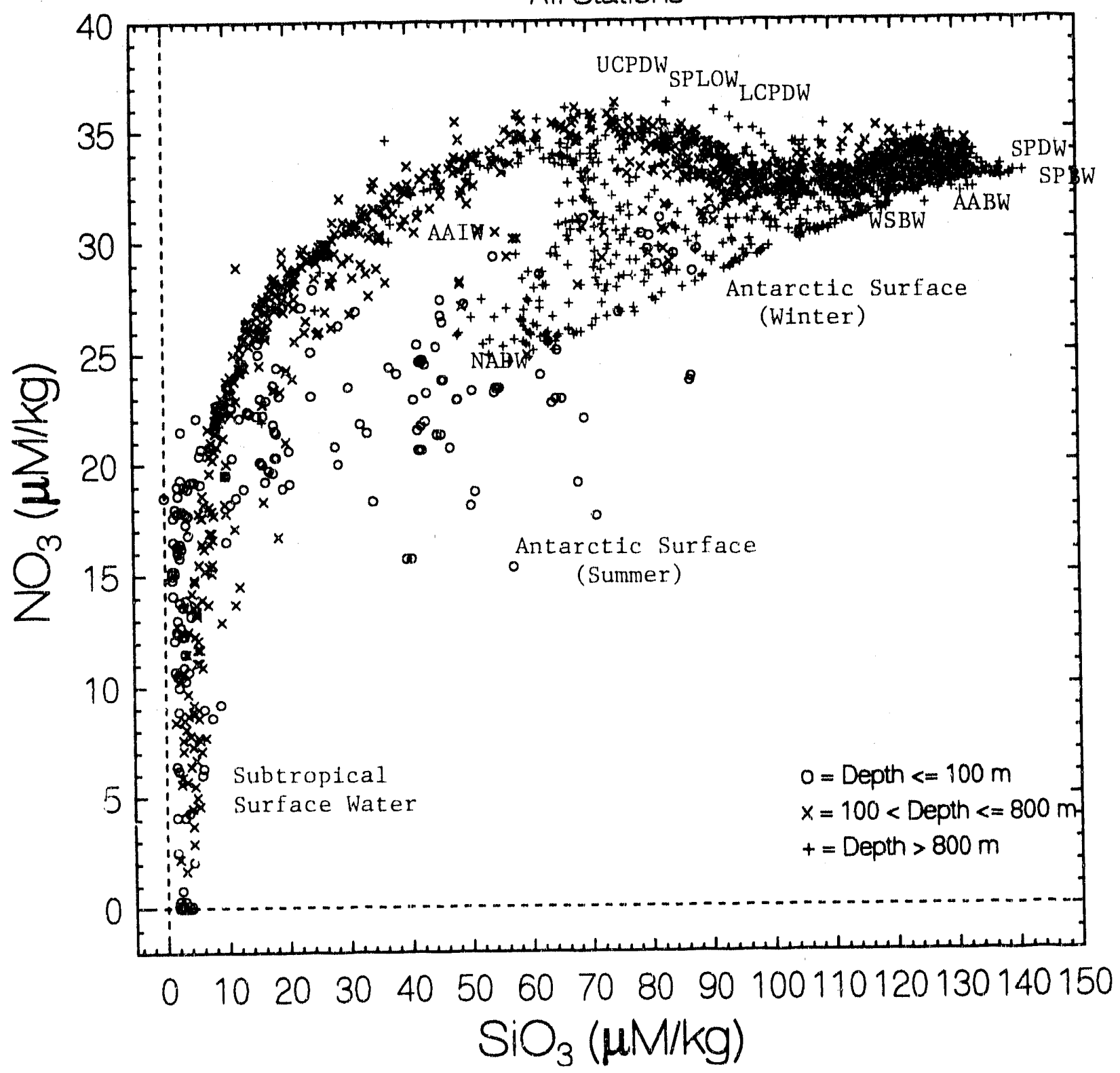


Fig. 76 shows the relationships between the potential alkalinity and salinity. The potential alkalinity has been computed by [(Total Alkalinity) + (Nitrate)] (Brewer and Goldman, 1977) and has been normalized to a salinity of $35.00 \mathrm{o} / \mathrm{o0}$. The potential alkalinity values for the summer and winter Antarctic surface waters are nearly constant, whereas the total $\mathrm{CO}_{2}$ (Fig. 67), nitrate (Fig. 71), phosphate (Figs. 67 and 72) and silica (Ftg. 74) concentration indicate substantial reductions from winter to summer. This suggests that little production of $\mathrm{CaCO}_{3}$ occurred during the year in the Antarctic and Weddell Sea surface waters. On the other hand, the potential alkalinity values decrease rapidly in the subantarctic and subtropical surface waters, suggesting production of calcareousi shells.

As mentioned earlier, the Cape Basin Botton Water (CBBW) has the highest potential alkalinity values, whereas the NADW is depicted as a sharp minimum in the vicinity of $34.8 \mathrm{o} / 00$ salinity.

Fig. 77 shows the relationships between the potential alkalinity and the silica concentration. The potential alkalinity values are normalized to a salinity of $35.00 \mathrm{o} / \mathrm{oo}$. In the Antarctic surface waters, it is observed that the potential alkalinity values are nearly constant with a slight decline to lower silica values during the summer and winter seasons and that these surface water values are only slightly smaller than the deep water values (see "x" and "+" signs). This indicates that only a small amount of $\mathrm{CaCO}_{3}$ is removed from the Antarctic and Weddell Sea surface water, while the silica concentration in these waters is reduced to near-zero values by the growth of silica secreting organisms. The potential alkalinity is reduced only after silica concentrations reach near-zero values. This suggests that the production of biogenic $\mathrm{CaCO}_{3} \mathrm{OC}$ curs mainly in the subantarctic and subtropical surface waters. 
Fig. 76 - Relationships between the potential alkalinity and salinity observed during the $\mathrm{F} / \mathrm{S}$ Meteor Expedition, Jan.-March, 1990, in the South Atlantic Ocean and northern Weddell Sea. Potential alkalinity is computed by (Total Alkalinity) + (Nitrate), and is normalized to a salinity of $35.00 \% / 00$. The highest potential alkalinity values were observed near the bottom of the Cape Basin, southeastern Atlantic.

\section{F/S Meteor Cruise 11/5}

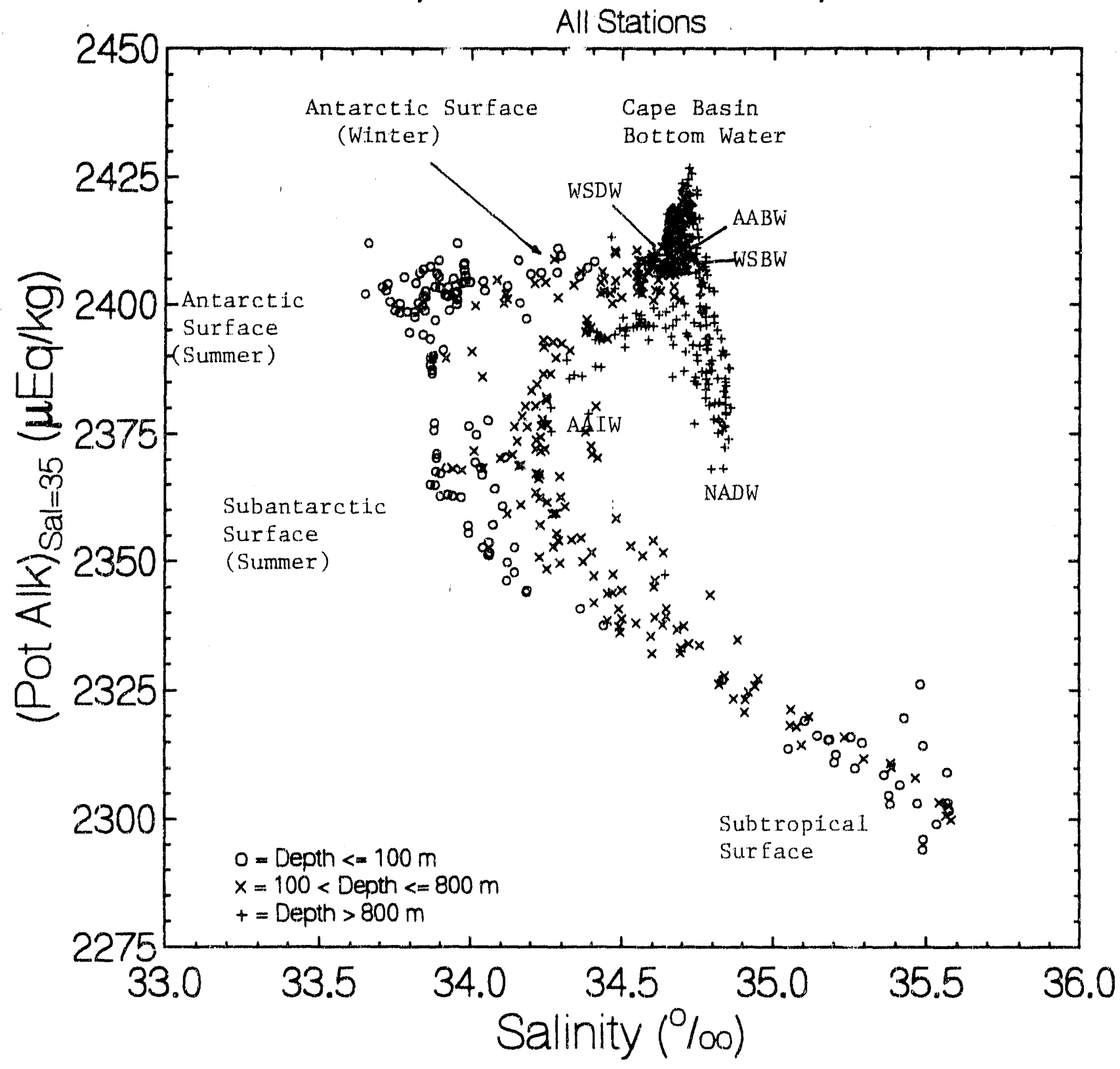


Fig. 77 - Relationships between the potential alkalinity and the concentration of stlica in seawater. The former is normalized to a salinity of $35.00 \mathrm{0} / 00$. UCPDW $=$ Upper Circumpolar Deep Water; SPBW = Southeast Pacific Bottom Water; WSDW and WSBW = Weddell Sea Deep and Bottom Waters; and NADW = North Atlantic Deep Water.

\section{F/S Meteor Cruise 11/5}

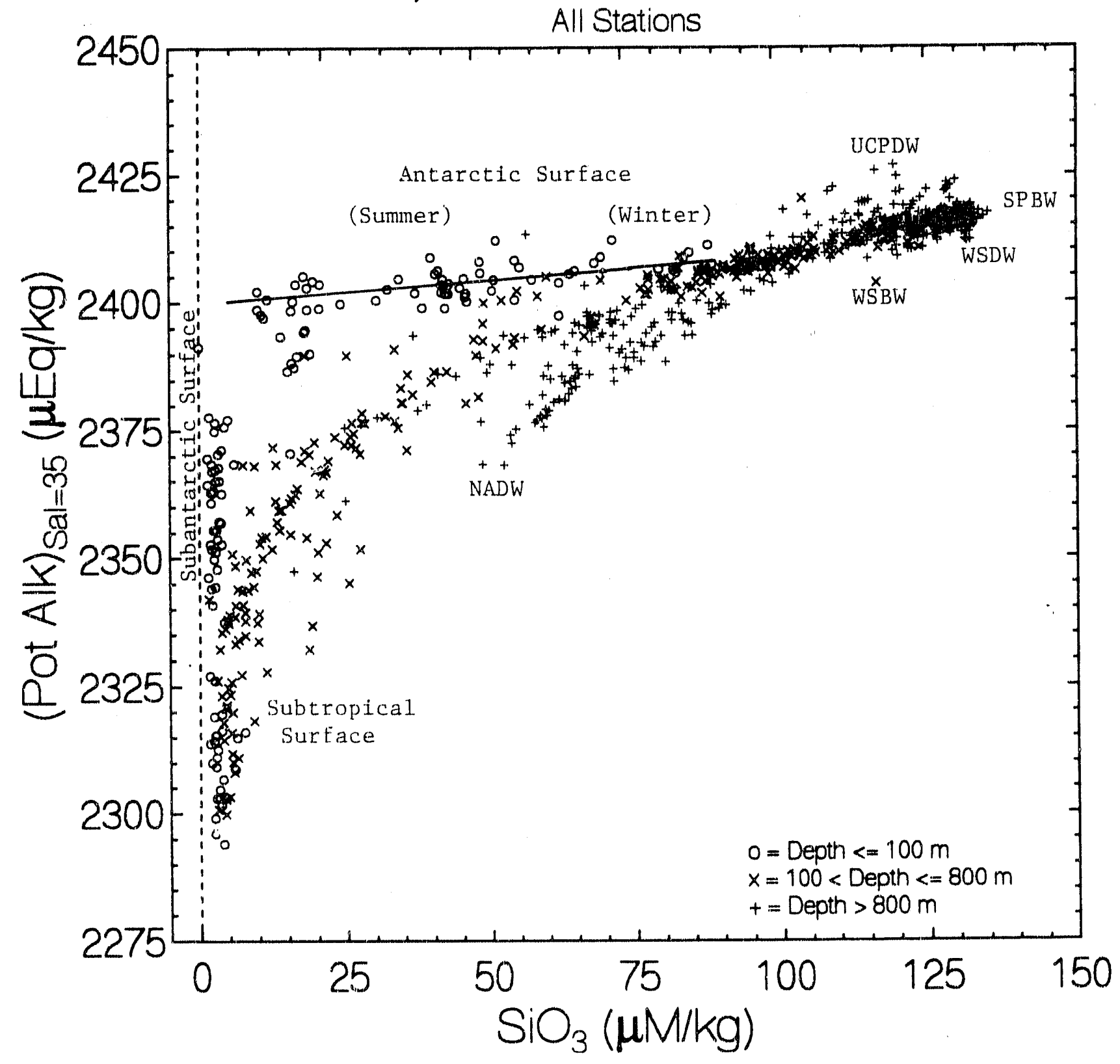




\section{REFERENCES CITED}

Brewer, P. G. and J. C. Goldman (1976). Alkalinity changes generated by phytoplankton growth. Lim. and Oceanogr., 21, 108-117.

Bryden, H. L. (1973), New polynomials for thermal expansion, adiabatic temperature gradient and potential temperature of seawater. Deep-Sea Res., 20, $401-408$.

Carmack, E.. C. and T. D. Foster (1975). On the flow of deep water out of the Weddell Sea. Deep Sea Res., 22, 711-724.

Chipman, D. W. and J. Goddard (1991). Technical manual for gas chromatographic system for high precision measurements of carbon dioxide partial pressures in discrete ocean water and air samples. Final Technical Report for DOE Contract 19X-91319C, Lamont-Doherty Geol. Obs., Palisades, NY, pp.40.

Culberson, C. H. and R. M. Pytkowicz (1973). Ionization of water in seawater. Mar. Chem., 1, 403-417.

Fofonoff, N. P. (1980), Computation of potential temperature of seawater for an arbitrary reference pressure, Deep-Sea Res., 24, 489-491.

Gordon, A. L. (1971-a). Oceanography of Antarctic waters. in "Antarcic Oceanography I", J. L. Reid, editor, Antarctic Research Series, Vol. 15, Am. Geophys. Union, Washington, D. C., 169-203.

Gordon, A. L. (1971-b). Antarctic polar front zone, in "Antarctic Oceanography I", J. L. Reid, editor, Antarctic Research Series, Vol. 15, Am. Geophys. Union, Washington, D. C., 205-221.

Gordon, A. L. and E. J. Molinelli (1982). Thermohalince and chemical distributions and the atlas data set. in "Southern Ocean Atlas", Columbia University Press, New York, 248 plates and 33 pages.

Ingri, N. (1959). Equilibrium studies of polyanions, IV. Silicate ions in NaCl medium. Acta Chem Scand., $13,758-775$.

Johnson, K. M., A. E. King. and J. McN. Sieburth (1985). Coulometric $\mathrm{TCO}_{2}$ analyses for marine sturlies: an introduction. Mar. Chem., 16, 61-82.

Jacobs, S. S., R. G. Fairbanks and Y. Horibe (1985). Origin and evolution of water masses near the Antarctic continental margin: evidence from $\mathrm{H}_{2}{ }^{18} \mathrm{O} / \mathrm{H}_{2}{ }^{16} \mathrm{O}$ ratios in seawater. in "Oceanology of the Antarctic Continental Shelf", S. S. Jacobs editor, Antarctic Research Series \#43, Amer. Geophys Union, Washington, D. C., 59-85.

Kester, D. R. and R. M. Pytkowicz (1967). Determination of the apparent dissociation constants of phosphoric acid in seawater. Limnol. Oceanogr., 12, 243-252.

Kester, D. R. (1975), Dissolved gases other than $\mathrm{CO}_{2}$. in "Chemical Oceanography", 2nd Edition, J. P. Riley, G. Skirrow editors, Vol. 1, 497-556, Academic Press, London. 
Lyman, J. (1956). Buffer mechanism of sea water. Ph.D. Thesis, University of California, Los Angeles, Los Angeles, California, $196 \mathrm{pp}$

Mehrbach, C., C. H. Culberson, J. E. Hawley, and R. M. Pytkowicz (1973). Measurement of the apparent dissociation constants of carbonic acid in seawater at atmospheric pressure. Limnol. and Oceanogr., 18, 897-907.

Millero, F. J., C.-T. Chen, A. Bradshaw and K. Schleicher (1980), A new high pressure equation of state for seawater. Deep-Sea Res., 27, 255-264.

Millero, F. J. (1979). The thermodynamics of the carbonate system in seawater. Geochim. et Cosmochim. Acta, 43, 1651-1661.

Murray, N. N. and J. P. Riley (1969) The solubility of gases in distilled water and sea water - II. Oxygen. Deep-Sea Res., 16, 311-320.

Peng, T.-H., T. Takahashi, W. S. Broecker, J. Olafsson (1987). Seasonal variability of carbon dioxide, nutrients and oxygen in the northern North Atlantic surface water: Observations and a model, Tellus, 39B, 439-458.

Reid, J. L., Nowlin, W. D. Jr., Patzert, W. C. (1977). On the characteristics and circulation of the southwestern Atlantic Ocean. Jour. Phys. Ocean., 7, 62-91.

Takahashi T., D. Chipman, N. Schechtman, J. Goddard and R. Wanninkof (1982). Measurements of the partial pressure of $\mathrm{CO}_{2}$ in discrete water samples during the North Atlantic Expedition, the Transient Tracers of Oceans Project. Technical Report to NSF, Lamont-Doherty Geological Observatory, Palisades, NY, pp. 268.

Weiss, R. F. (1974). Carbon dioxide in water and seawater: The solubility of a non-ideal gas, Marine Chem., 2, 203-215.

Weiss, R. F. (1981). Determinations of $\mathrm{CO}_{2}$ and methane by dual catalyst flame ionization chromatography and nitrous oxide by electron capture chromatography. Jour. of Chromatogr. Sci., 12, 611-616.

Whitworth, T. III and W. D. Nowlin (1987). Water masses and currents of the Southern Gcean at the Greenwich Meridian, Jour. Geophys. Res., 22, 6462-6476. 


\section{DATA TABLES}

Because of the agreements made by the participants of WOCE expeditions, the numerical data for the expedition will not be released to the public domain until two full years will be passed after the end of the expedition. Accordingly, the data will be released in the end of March, 1992. All the data obtained during the expedition have been submitted to the Carbon Dioxide Information and Analysis Center at the Oak Ridge National Laboratory for archiving and for the distribution to the public after March, 1992.

The data are presented in two sections. The first is to summarize the chemical data for surface waters as well as the atmospheric $\mathrm{CO}_{2}$ concentration and the sea-air $\mathrm{pCO}_{2}$ difference. The second is to list the total $\mathrm{CO}_{2}$ concentration and $\mathrm{pCO}_{2}$ data as well as the associated hydrographic data. The latter data set was obtained by the participating members of the Oceanographic Data Facilities of Scripps Institution of Oceanography, and the members of the University of Bremen and other German scientific institutions and the Argentine Hydrographic Office. 

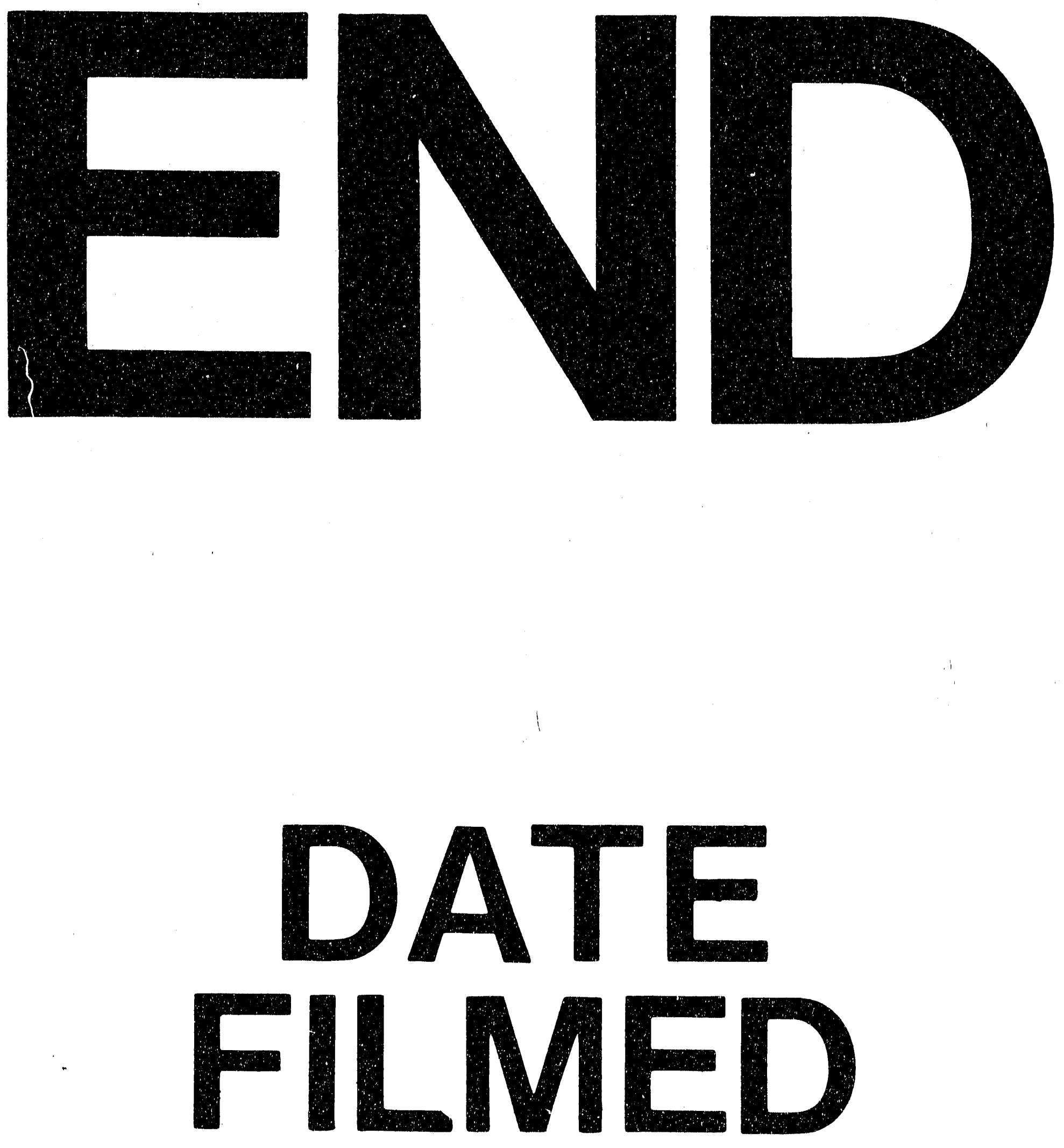

$\frac{1}{3}$

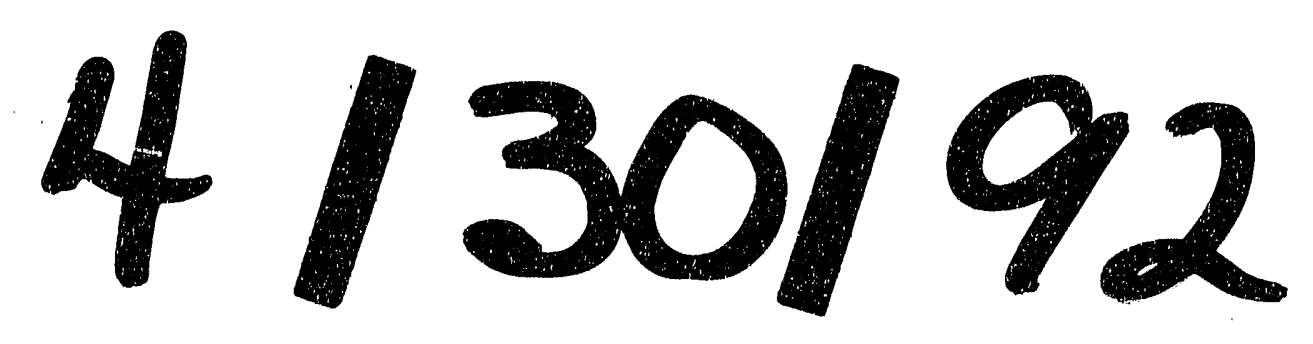


